$$
\frac{27}{8 \cdot 10} \cdot 16
$$

\title{
Environmental Surveillance at Hanford for CY-1975
}

June 1976

Prepared for the Energy Research and Development Administration under Contract E(45-1):1830

$x$




\section{DISCLAIMER}

This report was prepared as an account of work sponsored by an agency of the United States Government. Neither the United States Government nor any agency Thereof, nor any of their employees, makes any warranty, express or implied, or assumes any legal liability or responsibility for the accuracy, completeness, or usefulness of any information, apparatus, product, or process disclosed, or represents that its use would not infringe privately owned rights. Reference herein to any specific commercial product, process, or service by trade name, trademark, manufacturer, or otherwise does not necessarily constitute or imply its endorsement, recommendation, or favoring by the United States Government or any agency thereof. The views and opinions of authors expressed herein do not necessarily state or reflect those of the United States Government or any agency thereof. 


\section{DISCLAIMER}

Portions of this document may be illegible in electronic image products. Images are produced from the best available original document. 
NOTICE

This report was prepared as an account of work sponsored by the United States Government. Neither the United States nor the Energy Research and Development Administration, nor any of their employees, nor any of their contractors, subcontractors, or their employees, makes any warranty, express or implied, or assumes any legal liability or responsibility for the accuracy, completeness or usefulness of any imformation, apparatus, product or process disclosed, or represents that its use would not infringe privately owned rights.

PACIFIC NORTHWEST LABORATORY

operated by

BATTELLE

for the

ENERGY RESEARCH AND DEVELOPMENT ADMINISTRATION

Under Contract E(45-1)-1830

Printed in the United States of America

Available from

National Technical Information Service

U.S. Department of Commerce

5285 Port Royal Road

Springfield, Virginia 2215

Price: Printed Copy Microfiche $\$ 2.25$

5.4 
BNWL-1979 (REV)

UC -41

ENVIRONMENTAL SURVEILLANCE AT HANFORD FOR CY-1975

Dwayne R. Speer

Jack J. Fix

Peggy J. Blumer

Occupational and Environmental Safety Department

June 1976

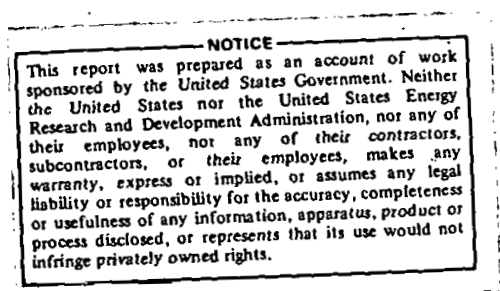

BATTELLE

PACIFIC NORTHWEST LABORATORIES

RICHLAND, WASHINGTON 99352

\section{MASTER}




\section{FOREWORD}

The Environmental Surveillance Program at Hanford is conducted by Battelle, Pacific Northwest Laboratory (also referred to as Battelle-Northwest or BNW) and Hanford Environmental Health Foundation (HEHF) under contract to the Energy Research and Development Administration (ERDA). Efforts by BNW are designed, primarily, to measure the levels of radiation in the environs of Hanford and to determine the respective components of these levels whether of natural causes, nuclear testing fallout, or Hanford operations. Other environmental data are collected on the chemical and biological quality of river water.. HEHF collects data on air quality in the Hanford environs and on the chemical and biological quality of sanitary water. When appropriate, the data are compared with applicable standards for air and water quality set forth by the Energy Research and Development Administration, Environmental Protection Agency (EPA), U. S. Public Health Service and Washington State. Interpretation and summaries of the data are presented annualiy; the present document is for calendar year 1975. 


\section{CONTENTS}

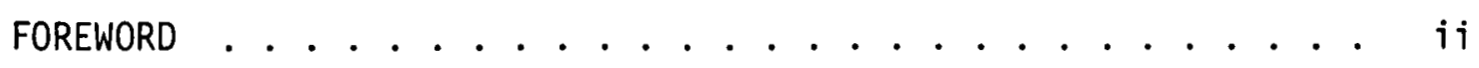

LIST OF FIGURES . . . . . . . . . . . . . . . . . . . . . v

LIST OF TABLES . . . . . . . . . . . . . . . . . . v v

INTRODUCTION . . . . . . . . . . . . . . . . . . . . . 1

SUMMARY . . . . . . . . . . . . . . . . . . . . 7

ENVIRONMENTAL SAMPLE COLLECTION, ANALYSIS, AND EVALUATION . . . 10

General ..................... 10

Air ........................ 11

Radiological Evaluation............... . 11

Nonradiological Evaluation ............. 15

Water ..................... . 17

Columbia River . . . . . . . . . . . . . 17

Radiological Evaluation .............. . 17

Nonradiological Evaluation . . . . . . . . . 20

Sanitary Water . . . . . . . . . . . . . 23

Radiological Evaluation................ 23

Nonradiological Evaluation ............. . 24

Groundwater ................ . . 25

Foodstuff . . . . . . . . . . . . . . . . 26

Wildlife...................... . . . 28

Soil and Vegetation ................ . . . 30

External Radiation Measurement . . . . . . . . . . 37

Ambient Radiation Dose .. . . . . . . . . . 37

Columbia River Immersion Dose ........... . 39

Portable Instrument Surveys . . . . . . . . . . . 40

RADIOLOGICAL IMPACT OF HANFORD OPERATIONS . . . . . . . . . . 41 


\section{CONTENTS (Cont.)}

Radiological Impact from 1975 Effluent . . . . . . . 44

Maximum "Fence-Post" Exposure Rate ........ . . 44

Maximum Individual Dose ............ 44

80-Kilometer Radius Population Dose . . . . . . . 48

Radiological Impact from Observed Radioactivity

Due to Past Hanford Operations . . . . . . . . . . . 51

STANDARDS ........................ 53

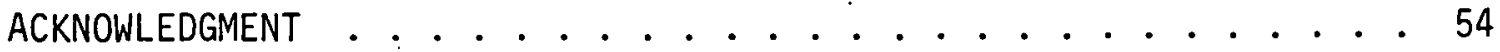

APPENDIX A

Synopsis of Filter-Resin Sampling Method .........A-l

APPENDIX B

Radiochemical Analyses ............. . . B-1

APPENDIX C

Hanford Environmental Health Foundation's

Chemistry Laboratory Certification ............ C-1

APPENIIX D

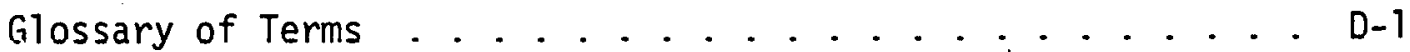




\section{LIST OF FIGURES}

1. Geographical Location of Hanford and Surrounding Areas . . . . . 2

2. Features of the Hanford Site and Vicinity . . . . . . . . . . $3^{\text {. }}$

3. Hanford Environmental Air Sampling Locations During 1975 . . . . 11

4. Monthly Average Gross Beta Activity in the Atmosphere . . . . 14

5. Columbia River Monthly Temperature at Richland and Priest Rapids Dam for 1975................ . . 21

6. Columbia River Daily Flow and Temperature During 1975 . . . . 21

7. Zinc-65 Concentration in Willapa Bay Oysters During 1970 Through 1975 ... . . . . . . . . . . . . 30

8. Soil Sediment and Groundwater Sampling Locations in the Vicinity of the Hanford Site . . . . . . . . . . . 31

9. Exposure Pathways to Man . . . . . . . . . . . . . . 42

\section{LIST OF TABLES}

1. Tritiated Water Vapor in the Air in 1975 . . . . . . . . 12

2. Radioactivity in Air - 1975. ............... 13

3. Concentration of Specific Radionuclides in Air - 1975 . . . . 16

4. Hanford Environs Air Quality Measurements - 1975 . . . . . . 17

5. Routine Analysis of Columbia River Water . . . . . . . . 18

6. Concentration of Radionuclides in the Columbia River at Priest Rapids.................... 19

7. Concentration of Radionuclides in the Columbia River at the 300 Area ................... . . 19

8. Columbia River Biologtcal Analyses - 1975 . . . . . . . . . 22

9. Columbia River Chemical Analyses - 1975 . . . . . . . . . 22

10. Radiological and Chemical Analyses of Drinking Water - 1975 . . 24 


\section{LIST OF TABLES (Cont.)}

11. Groundwater Analyses from Wells in the Vicinity of. Hanford - 1975 ................ 25

12. Concentrations of Radionuclides in Milk - $1975 \ldots \ldots$

13. Concentrations of Radionuclides in Meat, Chicken, and Eggs - 1975 .................. 27

14. Concentrations of Radionuclides in Leafy Vegetables -

Spinach, Leaf Lettuce, Turnip Greens, Mustard Greens - 1975 . . 27

15. Concentrations of Radionuclides in Muscle Tissue of Selected Wildlife Obtained from the Hanford Environs - 19/5 . . . . . 2 29

16. Concentrations of Radionuclides in Perimeter Soil Samples - 1975 ................ 32

17. Concentrations of Radionuclides in Perimeter Vegetation

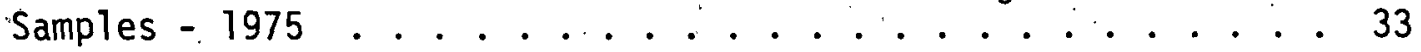

18. Concentrations of Radionuclides in Sediment Sampled at Columbia River Island and Shoreline Locations - 1975 . . . . 35

19. Depth Profile of Radionuclide Concentrations in Sediment Sampled at Selected Columbia River Island and Shoreline Locations - 1975 ............... . 36

20. Ambient Radiation Dose - 1975 . . . . . . . . 38

21. Columbia River Immersion Dose Rate - $1975 \ldots$. . . . . . . 39

22. Columbia River Shoreline Exposure Rate - $1975 \ldots 40$

23. Radionuclide Composition of Effluent - 1975 . . . . . . 43

24. Estimated Dose to the Maximum Individual During 1975 from Effluents Released from Hanford Facilities During 1975 . . 46

25. Estimated 50-Year Dose Commitment to the Maximum Individual from Effluents Released from Hanford Facilities During 1975 . . 47

26. Estimated Population Dose During 1975 from Effluents Released from Hanford Facilities During 1975 ......... 49

27. Estimated 50-Year Population Dose Commitment from Effluents Released from Hanford Facilities During 1975 ....... . 50

B-1 Interlaboratory Comparison of Analytical Results . . . . B-3 


\title{
ENVIRONMENTAL SURVEILLANCE AT HANFORD FOR CY1975
}

\author{
Dwayne R. Speer \\ Jack J. Fix \\ Peggy J. B1 umer
}

The Hanford plant was originally designed, built, and operated to produce plutonium for nuclear weapons. At one time, nine production reactors, eight with once-through cooling, were in operation. Between December 1964 and January 1971, al1 eight reactors with once-through cooling were deactivated. N Reactor, the remaining production reactor in operation, has a closed primary cooling loop. Steam from $N$ Reactor operation is used to drive turbine generators generating up to 860 million watts of electrical power in the Washington Public Power Supply System's Hanford Generating Plant. By the end of 1975, N Reactor had supplied steam to produce 32 billion kilowatt hours of electrical energy which was fed to the Bonneville Power Administration grid covering the Pacific Northwest.

During 1975, the work at Hanford included N Reactor operation, nuclear fuel fabrication, liquid waste solidification, continued construction of the Fast Flux Test Facility, continued construction of Washington Public Power Supply System (WPPSS) No. 2 power reactor, Arid Lands Ecology studies, as well as continued use of a variety of research and laboratory facilities. Privately owned facilities are located within the Hanford site boundaries including the WPPSS generating station adjacent to $\mathrm{N}$ Reactor, WPPSS power reactor site and office buildings, and a radioactive waste burial site. The Exxon fuel fabrication facility is located immediately adjacent to the southern boundary of the Hanford site.

The Hanford site is located in a semi-arid region of southeastern Washington State (Figure 1), occupying an area of about 1500 square kilometers (560 square miles). The site lies about 320 kilometers (200 miles) east of Portland, Oregon, 270 kilometers (170 miles) southeast of Seattle, Washington, and 200 kilometers (125 miles) southwest of Spokane, Washington. The Columbia River flows through the northern edge of the Hanford site and forms part of the eastern boundary. Figure 2 shows the location of 


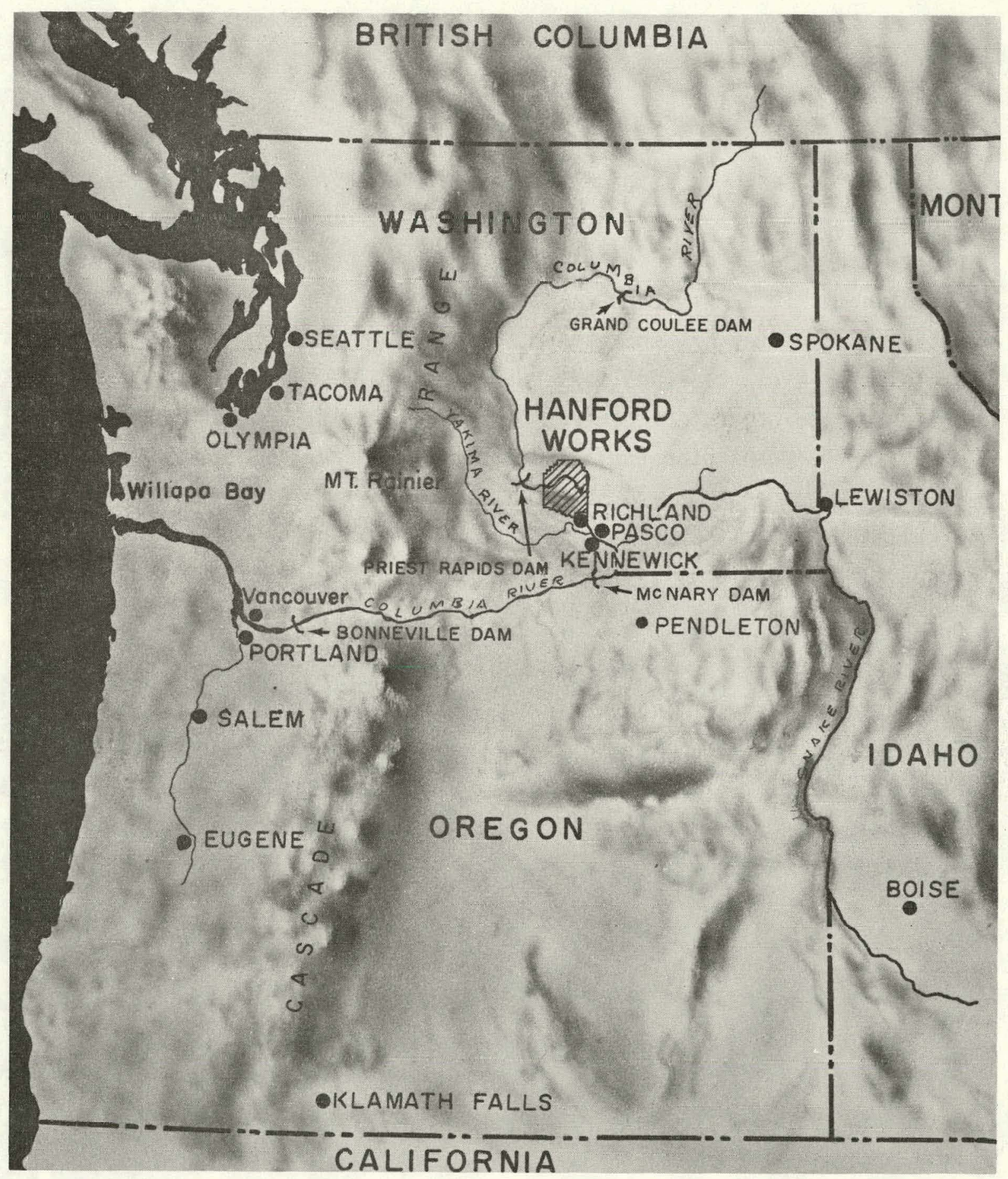

FIGURE 1. Geographical Location of Hanford and Surrounding Areas 


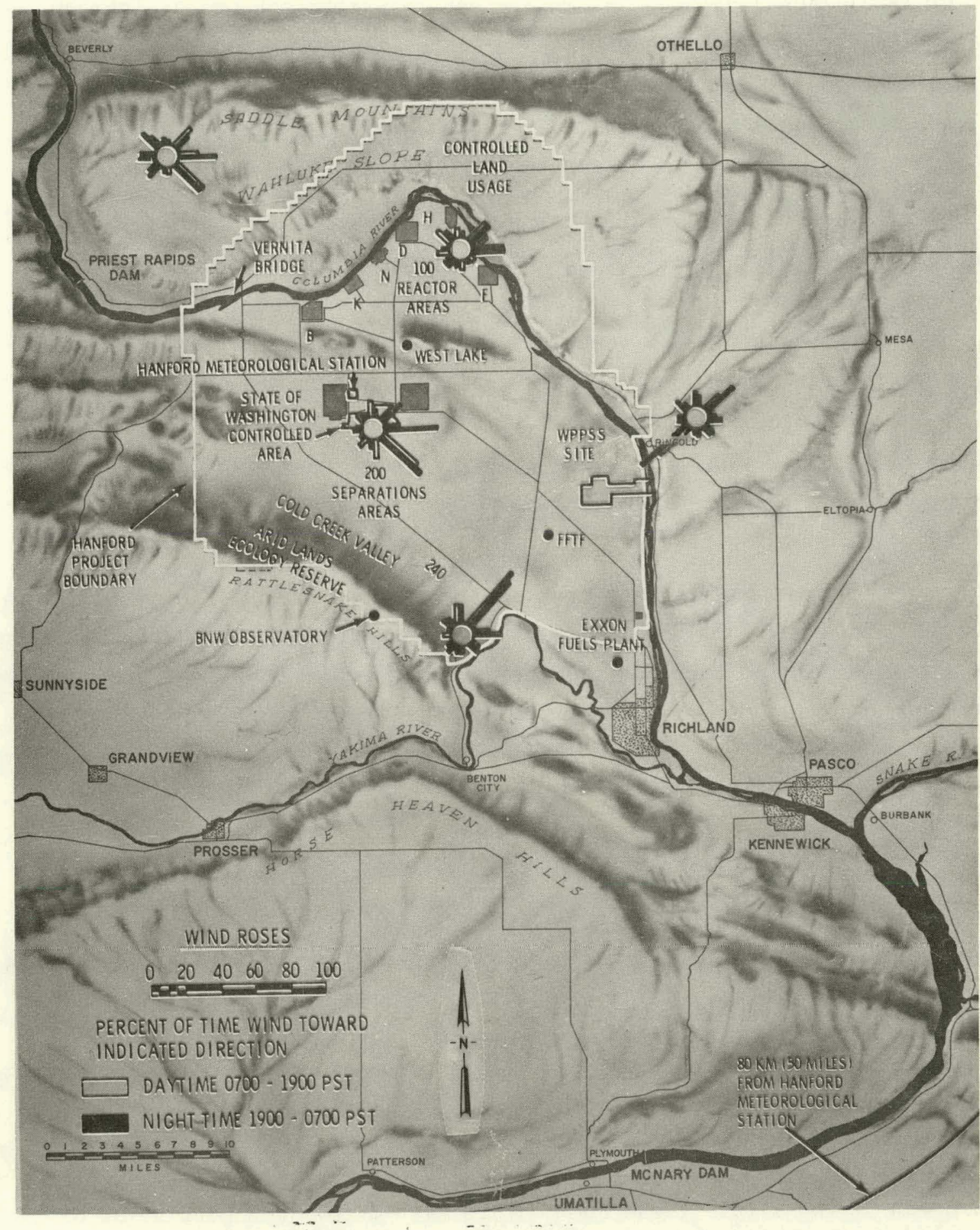

FIGURE 2. Features of Hanford Site and Vicinity 
reactor facilities along the Columbia River in what are known as the 100 Areas. The reactor fuel processing and waste management facilities are on a plateau about 7 miles from the river in the 200 Areas. The 300 Area, just north of Richland, contains the reactor fuel manufacturing facilities and research and development laboratories.

The desert plain on which Hanford is located has a sparse covering of vegetation primarily suited for grazing, although extensive areas near the site have gradualiy been put under irrigation during the past several years. The most broadly distributed vegetation type on the site is the sagebrush/ cheatgrass/bluegrass community. Mule deer is the only big game mammal found; the cottontail rabbit is the most abundant small game animal. The raccoon is probably the most abundant furbearing animal. The osprey, golden eagle, and bald eagle are all occasional visitors to the relatively large areas of uninhabited land comprising the Hanford site.

The Hanford climate is mild and dry, receiving approximately $16 \mathrm{~cm}$ (6.3 in.) of precipitation annually. The months of November, December, and January contribute about $40 \%$ of the total precipitation, whereas July, August, and September contribute only $10 \%$. The average maximum and minimum temperatures in July are $33^{\circ} \mathrm{C}\left(92^{\circ} \mathrm{F}\right)$ and $16^{\circ} \mathrm{C}\left(61^{\circ} \mathrm{F}\right)$. For January, the respective averages are $3^{\circ} \mathrm{C}\left(37^{\circ} \mathrm{F}\right)$ and $-6^{\circ} \mathrm{C}\left(22^{\circ} \mathrm{F}\right)$. Approximately $45 \%$ of all precipitation during the months of December through February is in the form of snow. Mean monthly wind speeds range from about $14 \mathrm{~km} / \mathrm{hr}$ ( $9 \mathrm{mph}$ ) in the summer to $10 \mathrm{~km} / \mathrm{hr}$ ( $6 \mathrm{mph}$ ) in the winter. As indicated by the wind roses shown in Figure 2, the prevailing regional winds are from the northwest, with strong drainage and crosswinds causing complicated surface flow patterns. The region is a typical desert area, with frequent strong inversions occurring at night but breaking during the day causing unstable and turbulent conditions.

The nearest population center to the Hanford site is the Tri-Cities area (Richland, Pasco, and Kennewick) situated on the Columbia River directly downstream of the site. These communities with a combined population of approximately 80,000 utilize the Columbia River as a source of drinking water. Approximately 250,000 people reside within a 80 kilometer (50-mile) radius of the Hanford Meteorological Station (HMS) located in the 200 Area 
of the Hanford site (Figure 1). This population is composed of the Yakima area, Tri-Cities, several small communities, and the surrounding agricul-: tural community. The economy of the area, with the exception of Hanford: related industries, is primarily agricultural. Primary crops include alfalfa, hay, wheat, sugar beets, and potatoes. Several fruit orchards are located within a short distance of the Hanford site. The Columbia River is extensively used for recreational purposes including fishing. The principal operating contractors at Hanford are:

- Atlantic Richfield Hanford Company (ARHCO)--Responsible for fuel processing, waste management, and all site general support services such as plant security, fire protection, central stores, electrical power distribution, etc.

- Battelle-Northwest (BNW)--Responsible for the operation of the Pacific Northwest Laboratories of Battelle Memorial Institute which includes research in general areas of. life sciences, environmental science, environmental surveillance, advanced methods of nuclear waste management, and a wide variety of other physical and biological sciences.

- United Nuclear Industries (UNI)--Responsible for operation of $\mathbf{N}$ Reactor and for $\mathrm{N}$ Reactor fuel fabrication.

- Westinghouse Hanford Company (WHC)--Responsible for the operation of the Hanford Engineering Development Laboratory (HEDL) which includes advanced reactor developments, principally the Liquid Metal Fast Breeder Program and the Fast Flux Test Reactor (FFTF).

The Hanford Environmental Surveillance Program is conducted by BNW and Hanford Environmental Health Foundation (HEHF) under contract to the Energy Research and Development Administration (ERDA). The program is designed, primarily, to measure the levels of radiation in the Hanford environs and to determine the respective components of the levels whether of natural causes, worldwide fallout, or Hanford operations. Other environmental data are collected on nonradioactive pollutants in air in the Hanford area and on chemical and biological quality of Columbia River and sanitary 
water. The data are reported and evaluated in a series of annual reports; the present report evaluates data collected during 1975. Detailed analytical data are published in a separate report (BNWL-1980).

For each set of data where each individual analysis yielded a positive value, an annual average plus or minus two sample standard deviations (95\% confidence interval) was calculated. Many sets of data contain individual analyses which were less than the detection limit. In such cases, a less-than annual average was calculated from the data assuming that each less-than value was equal to the detection limit. This method maximizes the annual average. Any identifiable contribution to the observed concentrations of radioactivity in air or water attributable to Hanford operations was compared to ERDA Manual Chapter 0524 regulations. 1 Observed concentrations of nonradioactive pollutants were compared to applicable standards promulgated by the State of Washington ${ }^{2}$ or the Environmental Protection Agency. 3 


\section{SUMMARY}

Environmental data collected during 1975 showed continued compliance of Hanford operations with all applicable State and Federal regulations. Levels of radioactivity in the atmosphere from Hanford operations at all offsite sampling locations were indistinguishable from levels due to natural causes and worldwide fallout from the atmosphere. Air quality measurements of $\mathrm{NO}_{2}$ in the Hanford environs recorded a maximum yearly average concentration of $0.004 \mathrm{ppm}$ or $8 \%$ of the ambient air standard. There was no indication that Hanford operations contributed significantly to these levels. $\mathrm{All} \mathrm{SO}_{2}$ results were less than the detection limit of $0.005 \mathrm{ppm}$ or $25 \%$ of the ambient air quality standard.

Routine radiological, chemical, biological, and physical analyses of Columbia River water upstream and downstream of the Hanford Reservation did not show any identifiable effect due to Hanford operations with the possible exception of water temperature. Levels of radioactivity were similar at both locations and were indistinguishable from natural and fallout radioactivity. The dáta indicate an increase of coliform organisms, enterococci, and BOD for the downstream location. These increases are believed to be the result of drainage from farm activities and wildlife. The Hanford stretch of the river serves as a refuge for large populations of waterfowl. Nitrates, $\mathrm{pH}$, turbidity and dissolved oxygen measurements were similar at both locations. The temperature of the Columbia River between the upstream measurement station and the downstream station increases as a result of solar insolation and operations at Hanford. This part of the Columbia River is the last remaining stretch of free flowing Columbia River water in the United States and the amount of solar insolation can raise or lower the temperature of the river water significantly. The maximum temperature of the river water reached $20^{\circ} \mathrm{C}\left(67^{\circ} \mathrm{F}\right)$ during a few days during September. The annual average temperature and $95 \%$ confidence interval for Priest Rapids Dam and Richland during 1975 were 10.7士 $11.7^{\circ} \mathrm{C}$ and $11.1 \pm 11.7^{\circ} \mathrm{C}$, respectively, based on 365 daily measurements.

Beginning in October, 1975, water samples were collected at Priest Rapids, upstream of the Hanford site, and analyzed using a filter-resin system. ${ }^{5}$ 
This upstream sampler is used to provide background information for comparison to data obtained from a similar unit located at the 300 Area. The filter-resin system, described in Appendix A, has a much lower analytical detection limit than previously used methods and is used to determine the portion of radioactivity which is particulate in nature (suspended sediments) and that which is in solution. This information is especially useful in that most particulate matter is removed by sanitary water systems. The data collected in 1975 showed measurable levels of radioactivity in the river due to past operations of once-through cooling reactors and the continued operation of $\mathrm{N}$ reactor. The levels measured were all less than $0.2 \%$ of ERDAM 0524 drinking water standards for all radionuclides due to Hanford operations.

The majority of radioactivity measured in foodstuffs during 1975 was the result of naturally occurring $40 \mathrm{~K}$ and the fallout related radionuclides ${ }^{90} \mathrm{Sr}$ and ${ }^{137} \mathrm{Cs}$. Other radionuclides detected occasionally are also attributed to worldwide fallout. Cobalt-60 was measured in four of nine whitefish collected and is attributed to past once-through cooling production reactor operation. Soil samples collected in the Hanford environs did not show any identifiable contribution from Hanford operations with the exception of samples collected on the Columbia River islands, shoreline and slough areas. A few of these samples showed elevated levels of several radionuclides due to deposition on the islands of suspended sediment during periods of high water while the once-through cooling production reactors were in operation. Radioactivity from past once-through cooling production reactor operations was associated with the sediment.

External radiation levels in the Hanford environs were measured during 1975 by thermoluminescent dosimeters (TLDs) deployed at 17 different locations, TLDs immersed in the Columbia River at 4 locations, and several portable instrument surveys. The data collected during 1975 indicate that the average dose and 95\% confidence interval received from background radiation in the Hanford environs is approximately $72 \pm 18 \mathrm{mrem} /$ year. Adding the approximate 25 mrem received annually due primarily to internal dose from ${ }^{40} \mathrm{~K}$ yields an estimate of approximately $103 \pm i 8 \mathrm{mrem} /$ year due to all background sources. For convenience, the total background dose is assumed to be approximately $100 \mathrm{mrem} /$ year. 
The radiological impact of Hanford operations during 1975 has been estimated for three parameters: 1) the maximum "fence-post" exposure rate, 2) the maximum dose to an individual received during 1975 and the 50-year dose commitment due to 1975 effluent, and 3) the population dose received during 1975 and the 50-year dose commitment by the rapproximate 250,000 people residing within an 80-kilometer radius of the Hanford Reservation. The contribution of observed radioactivity in wildiaife, oysters, suspended sediment in the Columbia River, and on the islands from past once-through cooling production reactor operations to these parameters was also evaluated. The estimated values for these parameters are:

- The maximum "fence-post" exposure rate during 1975 occurred on the Columbia River islands. The maximum observed exposure rate was $0.014 \mathrm{mR} / \mathrm{hr}$ in addition to the approximate $0.010 \mathrm{mR} / \mathrm{hr}$ due to external background radiation. The source of the radiation was previous deposition of radioactivity attached to sediments on the islands during periods of high water flow. The radioactivity is due to past once-through cooling production reactor operation.

- The maximum total-body dose to an individual during 1975 and the 50-year dose commitment to this individual from effluent released during 1975 were $0.023 \mathrm{mrem}$ and $0.033 \mathrm{mrem}$, respectively. The contribution to this individual from external exposure on the islands would depend on the length of time spent on the islands and where the time was spent. Assuming the individual was at the point of maximum observed exposure, an additional dose of approximately 0.014 mrem would have been received for each hour spent at this point. It is unlikely that anyone would spend more than a. few hours each year on the islands.

- The total body dose to the population received during 1975 and the 50year dose commitment received from effluents released during 1975 were estimated to be 0.9 and 1.5 man-rem, respectively. The contribution to the population dose from the observed radioactivity is numerically insignificant.

For comparison, all members of the population receive approximately $100 \mathrm{mrem} /$ year from natural background radiation. The resulting total body population dose to the 250,000 people is approximately 25,000 man-rem. 


\section{ENVIRONMENTAL SAMPLE COLLECTION, ANALYSIS, AND EVALUATION}

GENERAL

Environmental surveillance at Hanford has been conducted throughout the nearly three decades of Hanford operations. Extensive radiological data collected during this time provide a historical record of environmental radioactivity due to Hanford operations, worldwide nuclear fallout, and natural causes. Levels of radioactivity in Columbia River water, sediments, and biota have been studied extensively to estimate the effect of past once-through cooling production reactor operations. Nonradioactive pollutants in air and water have been measured during the past several years. Monitoring activities during 1975 continued to measure the levels of pollutants, primarily radiological, in all significant environmental media. Environmental air sampling stations were operated at several locations in the vicinity of Hanford for the purpose of measuring radioactive and nonradioactive pollutants. Routine measurements were made of the chemical, biological, physical, and radiological quality of Columbia River water. Levels of radioactivity in Columbia River fish, local wildlife, and 10cally grown foodstuffs were routinely measured. Oysters from Willapa Bay were analyzed for ${ }^{65} \mathrm{Zn}$. External radiation levels were measured with environmental dosimeters, portable survey instruments, and an aerial survey.

In evaluating radiological data collected during 1975, the general philosophy was to compare radiation levels measured at locations potentialily affected by Hanford operations, with radiation levels measured at locations expected to reflect only radioactivity due to natural causes or worldwide nuclear fallout. Extensive data were collected for most environmental media to provide reliable estimates of the observed radioactivity which, in many cases, were near the detection limit of the analyses rather than unrealistic reliance on a few measurements.

A discussion of each major routine environmental sampling program follows. The location of each sampling station, the number of samples collected in 1975, and a summary and interpretation of the data are presented, for each program. 
$\underline{\text { AIR }}$

Air sampling responsibilities for the Hanford environs are divided between. BNW and HEHF. BNW is responsible for measuring the radiological parameters. while HEHF is responsible for nonradiological parameters.

\section{'Radiological Evaluation}

Radioactivity in the atmosphere was sampled by a network of 17 perimeter and 5 distant continuous air samplers during 1975 (Figure 3). Each air sampler maintains a flow of $2.5 \mathrm{~m}^{3} / \mathrm{hr}$ through a particle filter (Hollingsworth \& Vose Company, HV-70) and a $15-\mathrm{cm}$ long, 5-cm diameter charcoal cartridge. The system is expected to collect approximately $85 \%$ of the radioactivity associated with airborne dust and both organic and elemental forms of radioiodine. The system does not collect noble gases. The filters were collected biweekiy and analyzed for gross beta and alpha activity after

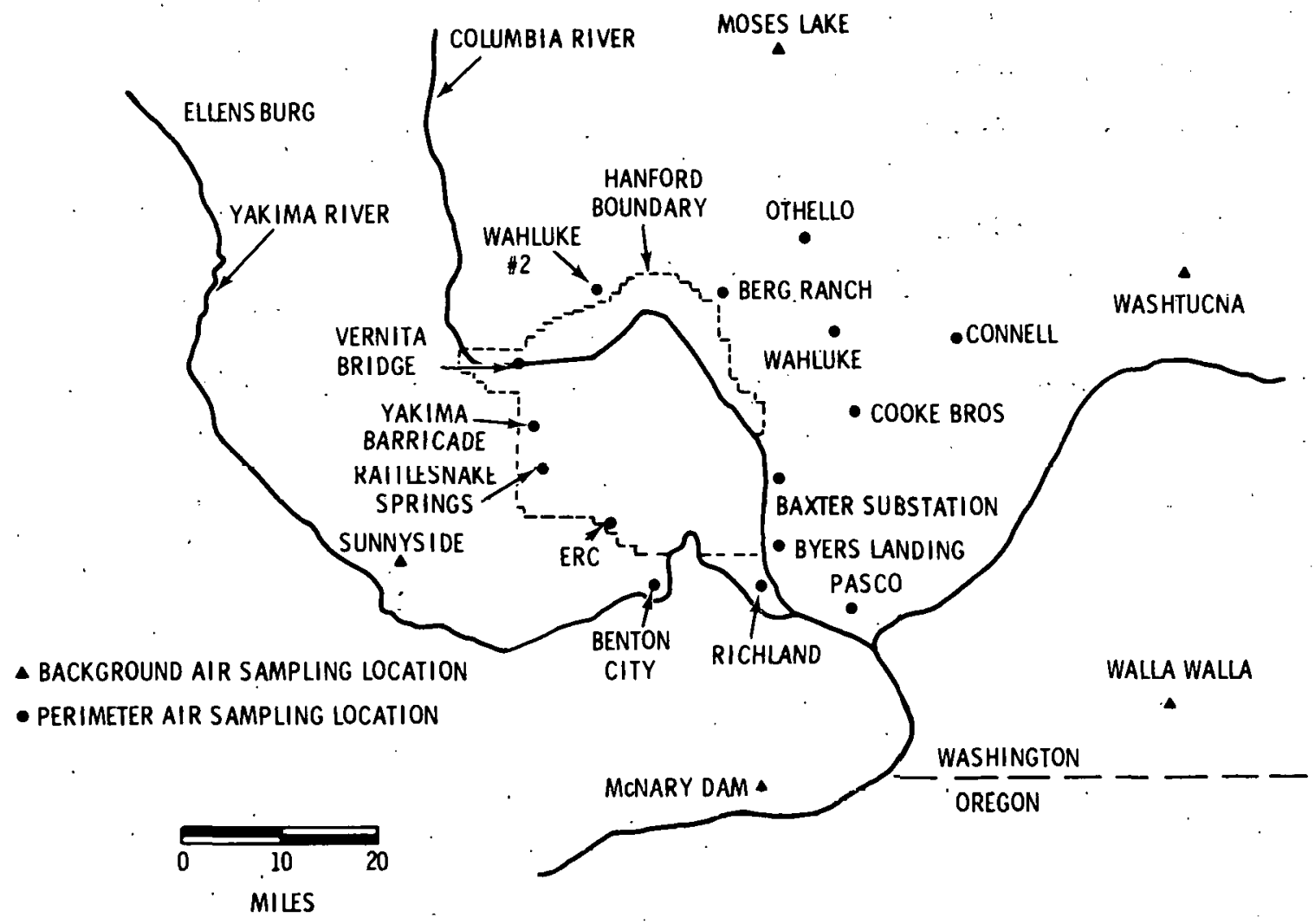

FIGURE 3. Hanford Environmental Air/Sampling Locations During 1975 
waiting 7 days to allow the short-lived radon and thoron daughters to decay. The filters were composited into groups according to geographical location and analyzed monthly by gamma spectrometry and quarterly for $90 \mathrm{Sr}$ and plutonium.

Tritiated water vapor was collected at three sampling stations (Berg Ranch, Baxter Substation, and Richland) by drawing air through a $25-\mathrm{cm}$ long by $5-\mathrm{cm}$ diameter cartridge of silica gel at the rate of $0.68 \mathrm{~m}^{3} / 24 \mathrm{hrs}$. The activity collected in this fashion was used to evaluate trends in air quality. There was no significant observable differences in values observed at the different stations due primarily to the variability of water vapor collection and measured tritium levels. The results of this sampling program are presented in Table 1 .

The results of gross beta, gross alpha, and ${ }^{131} \mathrm{I}$ analyses for perimeter and distant sampling locations are shown in Table 2. The distant stations are sufficiently remote from Hanford operations to insure that observed levels of radiation were due to natural causes or fallout. During 1975, airborne beta concentrations followed an atypical pattern, with the maximum concentrations occurring in the late winter and early spring

\section{TABLE 1. Tritiated Water Vapor in the Air in 1975}

\begin{tabular}{|c|c|c|c|c|c|c|c|}
\hline \multirow[b]{2}{*}{ Location } & \multirow[b]{2}{*}{$\begin{array}{l}\text { No. of } \\
\text { Samples }\end{array}$} & \multicolumn{3}{|c|}{$\begin{array}{c}\text { Tritium Concentration (a) } \\
(\mu \mathrm{Ci} / \mathrm{ml})\end{array}$} & \multicolumn{3}{|c|}{$\begin{array}{r}\text { Volume of Water collected (b } \\
(\mathrm{m}))^{(b}\end{array}$} \\
\hline & & Max. & Min. & Average $^{(c)}$ & Max. & Min. & Average $(c)$ \\
\hline Berg Ranch & 25 & $3.0 \times 10^{5}$ & * & $<1.6 \times 10^{3}$ & 32 & 5 & $16.8 \pm 13.3$ \\
\hline Baxter Substation & 23 & $5.1 \times 10^{4}$ & * & $<1.1 \times 10^{3}$ & 22 & 2 & $13.5 \pm 10.8$ \\
\hline \multirow[t]{2}{*}{ Richland } & 21 & $1.1 \times 10^{4}$ & * & $6.5 \times 10^{2}$ & 38 & 1 & $13.0 \pm 16.1$ \\
\hline & & \multicolumn{2}{|c|}{ Average $(c)$} & $<1.1 \times 10^{3}$ & & & $14.4 \pm 4.1$ \\
\hline
\end{tabular}

* Less than detectable. The minimum detectable activity is $370 \mu \mathrm{Ci} / \mathrm{ml}$.

(a) The tritium concentration in water vapor collected is used as a trend indicator only.

(b) The volume of water vapor collected is a function of the volume of air sampled, the relative humidity, and the air temperature.

(c) Average plus or minus two standard deviations when all analyses were positive; otherwise a less than number is reported using all results including less than values. 


\section{TABLE 2. Radioactivity in Air - 1975}

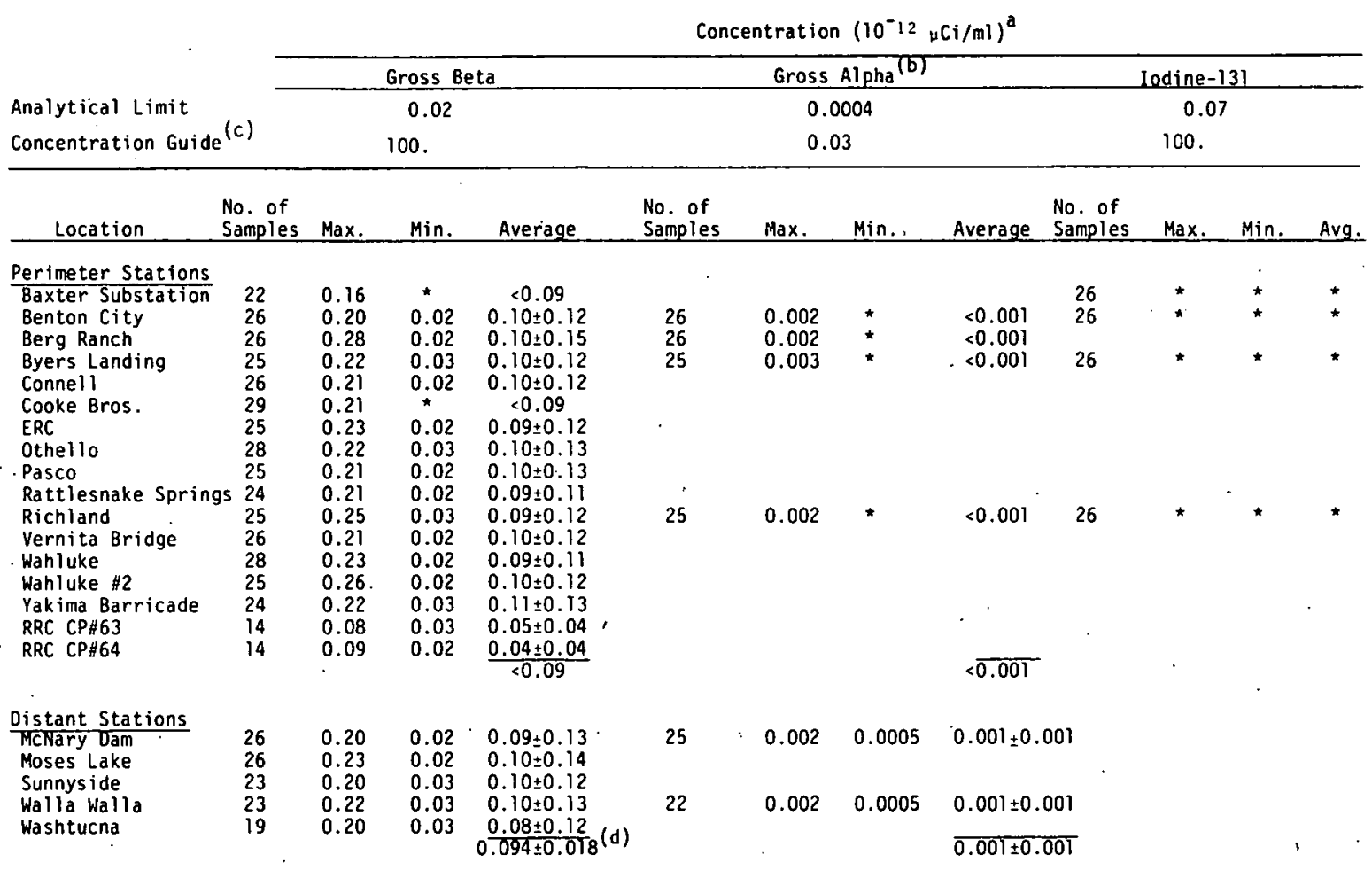

No entry indicates no analysis.
* Less than detectable.
(a) $1 \mathrm{pCi} / \mathrm{m}^{3}=10^{-12} \mathrm{\mu Ci} / \mathrm{ml}$. Average $\$ 2$ sample standard deviations shown $i f$ all analyses hadpositive results. 0therwise, a less than number is calculated from all results, including less than values.
(b) Gross alpha activity does not include any significant contribution due to naturally occurring radon and short-
(c) lived daughters in the air. The filters are held 7 days before analysis to allow radioactive decay of these radionuclides
(c) ERDA 0524 standards only apply to concentrations of radioactivity in excess of that due tonaturally occurrina or fallout radioactivity.
(d) Average \pm 2 Sample Standard Deviations.

and decreasing during the remainder of the year. Figure 4 illustrates the annual cyclic pattern observed from 1971 through 1975. The eastern quadrant stations called out in Figure 4 are in a predominately downwind direction from Hanford. The average beta concentration during 1975 observed at all perimeter stations was not significantly different than that observed at all distant stations. The average beta concentration for 1975 was $9 \times 10^{-14} \mu \mathrm{Ci} / \mathrm{ml}$ as compared to the 1974 average of $17 \times 10^{-14} \mu \mathrm{Ci} / \mathrm{ml}$. The highest observed 1975 gross beta concentration, $2.8 \times 10^{-} 13 \mu \mathrm{Ci} / \mathrm{ml}$, occurred at Berg Ranch on February 12.

The highest observed gross alpha concentration during 1975 occurred at Byers Landing $\left(3 \times 10^{-15} \mu \mathrm{Ci} / \mathrm{ml}\right)$ on February 26, 1975. Analyses for gross alpha concentrations in the atmosphere lack the sensitivity required to 


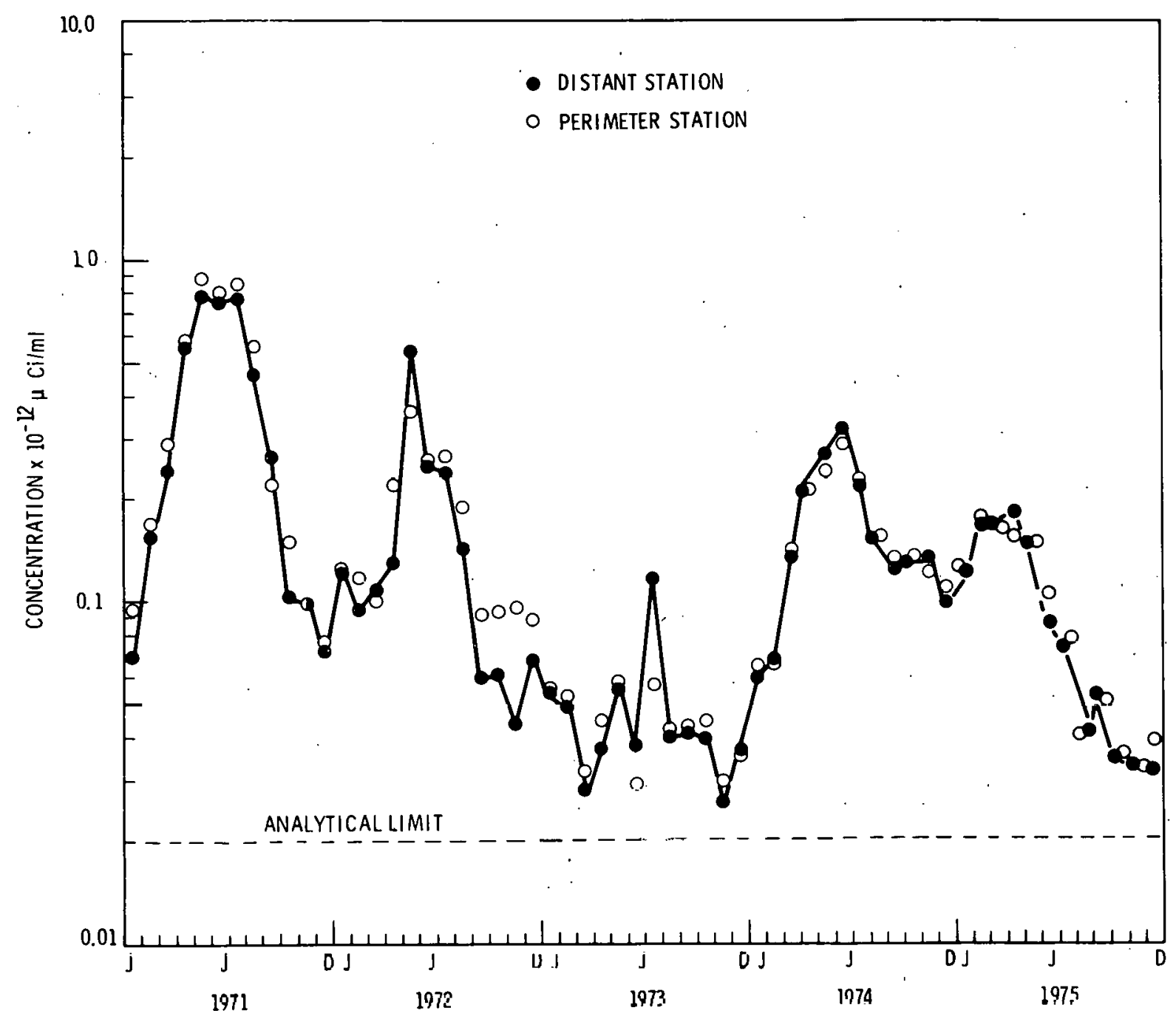

FIGURE 4. Monthly Average Gross Beta Activity in the Atmosphere

detect potential contributions from routine Hanford operations and, as such, were obtained at only a few locations in order to detect any unusual increases due to natural or fallout radioactivity. The annual average concentration of gross alpha radioactivity was about $1 \times 10^{-15} \mu \mathrm{Ci} / \mathrm{ml}$ at all locations as compared to $2 \times 10^{-15} \mu \mathrm{Ci} / \mathrm{ml}$ in 1974 .

Analysis for 131 I concentrations in the atmosphere were performed on a $b i$ weekly interval for 4 of the 17 perimeter sampling stations during 1975. Charcoal cartridges were located at all perimeter and distant sampling stations, thus providing available samples for analysis if the presence of 
iodine in the atmosphere had been indicated. The charcoal for these stations was changed monthly. Al1 131 I analyses during 1975 were less than the detection limit of $0.07 \times 10^{-12} \mu \mathrm{Ci} / \mathrm{ml}$, or less than $0.07 \%$ of the ERDA Manual Chapter 0524 standard of $1 \times 10^{-10} \mu \mathrm{Ci} / \mathrm{ml}$ for uncontrolled areas. 1 Results of specific radionuclide analyses are shown in Table 3 . Beryllium-7 is a naturally occurring radionuclide formed by the interaction of cosmic rays with nitrogen in the upper atmosphere. The other radionuclides are fission or activation products and result from either fallout, Hanford operations, or other nuclear facilities. The data show that all radionuclides, except for ${ }^{65} \mathrm{Zn}$, were observed in both perimeter and distant composite groups at approximately the same concentration. Zinc-65 was detected only once during the year and then at a concentration very near the analytical detection limit. Sunnyside, the point of detection, is quite distant from and 7 ies in a predominately upwind direction of the Hanford plant. The reported value of $2.3 \times 10^{-14} \mu \mathrm{Ci} / \mathrm{ml}$ is attributed to the expected analytical variability associated with environmental samples.

In summary, radioactivity observed at the perimeter environmental air sampling stations was indistinguishable from radioactivity observed at distant or background environmental air sampling stations. The radioactivity was attributed either to natural causes or to fallout from past nuclear device testing in the atmosphere.

Nonradiological Evaluation

HEHF, under contract to ERDA, is responsihile for monitoring the nnnradiological quality of the atmosphere in the Hanford environs. Monitoring activities during 1975 included 24-hour sequential sampling for $\mathrm{NO}_{2}$ and $\mathrm{SO}_{2}$ at three locations across the Columbia River from Richland, North Richland, and Hanford 300 Area operations. The three stations along the river were located in the southeasterly or downwind direction from Hanford operations. Table 4 summarizes the $\mathrm{NO}_{2}$ data collected during 1975. The highest yearly average concentration of $\mathrm{NO}_{2}$ measured was $0.004 \mathrm{ppm}$, or $8 \%$ of the ambient air standard of $0.05 \mathrm{ppm}$. All $\mathrm{SO}_{2}$ results were less than the detection limit of $0.005 \mathrm{ppm}$, or $25 \%$ of the ambient air standard of $0.02 \mathrm{ppm}$. 
TABLE 3. Concentration of Specific Radionuclides in Air - 1975

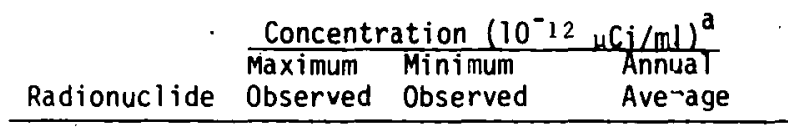

\begin{tabular}{llcl}
\multicolumn{5}{c}{ Inner } & Soutreast Quadrant \\
Be -7 & 0.09 & $\star$ & $<0.03$ \\
$\mathrm{Mn}-54$ & 0.004 & $\star$ & $<0.003$ \\
$\mathrm{Co}-60$ & 0.086 & $\star$ & $<0.007$ \\
$\mathrm{Sr}-90$ & 0.002 & $\star$ & $<0.0007$ \\
$\mathrm{Zr}-\mathrm{Nb}-95$ & 0.043 & $\star$ & $<0.013$ \\
$\mathrm{Ru}-106$ & 0.18 & $\star$ & $<0.1$ \\
$\mathrm{Cs}-137$ & 0.007 & $\star$ & $<0.001$ \\
Ce-Pr-144 & 0.072 & $\star$ & $<0.02$ \\
Total Pu & $9 \times 10^{-5}$ & $6 \times 10^{-6}$ & $(3 \pm 8) \times 10^{-5}$
\end{tabular}

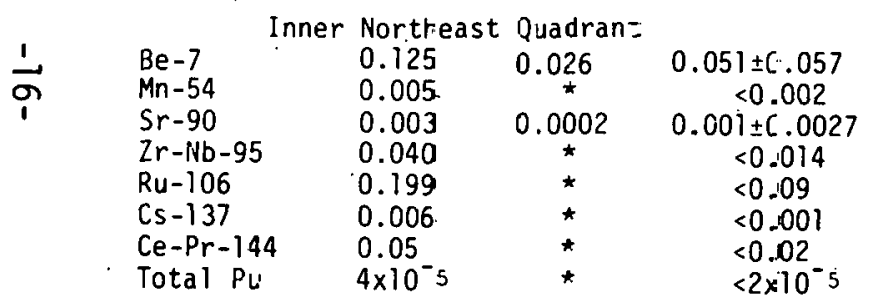

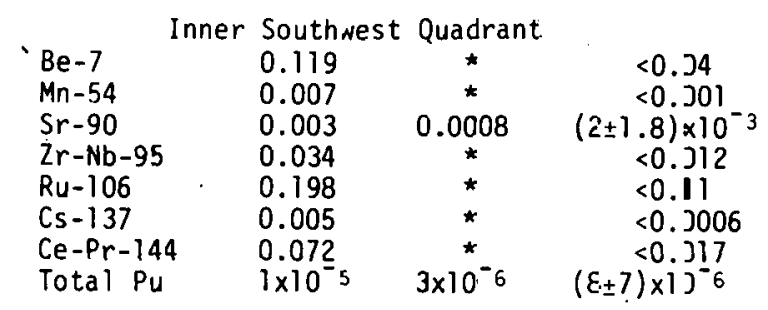

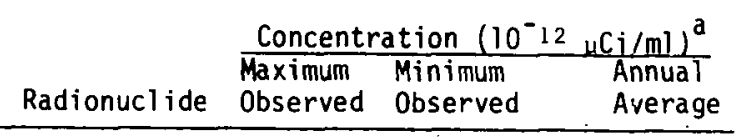

\begin{tabular}{llcc}
\multicolumn{5}{c}{ Cuter Southeast Quadrant } \\
Be-7 & 0.089 & $\star$ & $<0.03$ \\
Sr-90 & 0.002 & 0.000 .8 & $(1.5 \pm 1.3) \times 10^{-3}$ \\
Zr-Nb-95 & 0.032 & $\star$ & $<0.012$ \\
Pu-106 & 0.22 & $\star$ & $<0.13$ \\
Ce-Pr-144 & 0.03 & $\star$ & $<0.005$ \\
Total Pu & $4 \times 10^{-5}$ & $6 \times 10^{-6}$ & $(2 \pm 3) \times 10^{-5}$
\end{tabular}

Outer Northeast Quadrant

\begin{tabular}{llcl}
\multicolumn{5}{c}{ Quter Northeast Quadrant } \\
Ee-7 & 0.136 & $\star$ & \\
Mn-54 & 0.01 & $\star$ & $<0.03$ \\
Sr-90 & 0.003 & 0.001 & $<0.001$ \\
2r-Nb-95 & 0.033 & $\star$ & $(2 \pm 2) \times 10^{-3}$ \\
Fu-106 & 0.2 & $*$ & $<0.012$ \\
Cs-137 & 0.006 & $\star$ & $<0.11$ \\
Ce-Pr-144 & 0.064 & $\star$ & $<0.001$ \\
Total Pu & $1 \times 10^{-4}$ & $*$ & $<0.01$ \\
Total & & $<4 \times 10^{-5}$
\end{tabular}

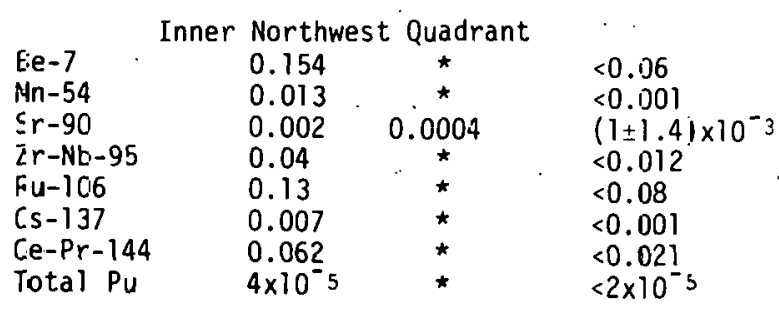

\begin{tabular}{llcl}
\multicolumn{3}{c}{ Outer Western Quadrant } & \\
Ee-7 & 0.18 & $\star$ & $\leq 0.03$ \\
Nn-54 & 0.014 & $\star$ & $<0.002$ \\
$2 n-65$ & 0.023 & $\star$ & $<0.001$ \\
Sr-90 & 0.01 & 0.0005 & $(3.6 \pm .1 .8) \times 10^{--}$ \\
Zr-Nb-95 & 0.04 & $\star$ & $<0.012$ \\
Fu-106 & 0.27 & $\star$ & $<0.09$ \\
Cs-137 & 0.01 & $\star$ & $<0.002$ \\
Total Pu & $6 \times 10^{-5}$ & $5 \times 10^{-6}$ & $(3 \pm 5) \times 10^{-5}$
\end{tabular}

ERDA 0524 Detection

\begin{tabular}{lcc} 
Radionuclide & $\begin{array}{c}\text { Standard } \\
\text { Stan }\end{array}$ & $\begin{array}{c}\text { Detection } \\
\text { Limit }\end{array}$ \\
\hline Be-7 & 40,000 & 0.03 \\
Mn-54 & 1,000 & 0.002 \\
Co-60 & 300 & 0.003 \\
Zn-65 & 2,000 & 0.006 \\
Sr-90 & 30 & 0.0002 \\
Zr-Nb-95 & 3,000 & 0.002 \\
Ru-106 & 200 & 0.04 \\
Cs-137 & 500 & 0.003 \\
Ba-La-140 & 1,000 & 0.15 \\
Ce-Pr-144 & 200 & 0.03 \\
Total Pu & 0.06 & $2 \times 10^{-6}$
\end{tabular}

NOTES

Less than detection limit.

(a) $\mathrm{j} \mathrm{pCi} / \mathrm{m}^{3}=10^{-12} \mu \mathrm{Ci} / \mathrm{ml}$

(b) Weekly air filters are composited into groups for monthly analys is by gamma spectroscopy or quarterly analys is for $5 r-90$ and total Pu. Specific stations included in each quadrant are: Inner Northeast; Othello, Connel1, Berg Ranch, Wahiuke $\mathrm{Wm}$, and Cooke Bros. Inner Southeast; Richland, Baxter Substation, Byers Landina, and Pasco: Inner Southwest;

Rattlesnake Springs, ERC and Benton City. Inner Northwest; Yakima Barricade, Vernia, and Wahluke \#2. Outer Northeast; Moses Lake and Washtucna. Outer Southeast; Walla Walla and McNary. Outer Western; Sunnyside.

(c) ERDA 0524 standards apply to radionuclide concentrations in excess of that occurring naturally or due to fallout. 
TABLE 4. Hanford Environs. Air Quality Measurements - 1975

\begin{tabular}{|c|c|c|c|c|c|}
\hline \multirow{2}{*}{\multicolumn{2}{|c|}{ Annual Air Quality Standard }} & \multicolumn{4}{|c|}{$\mathrm{NO}_{2}(\mathrm{ppm})$} \\
\hline & & & & .05 & \\
\hline Location & $\begin{array}{l}\text { No. of } \\
\text { Samples }\end{array}$ & $\begin{array}{l}\text { Daily } \\
\text { Max }\end{array}$ & $\begin{array}{l}\text { Daily } \\
\text { Min }\end{array}$ & $\begin{array}{l}\text { Annual } \\
\text { Average }\end{array}$ & $\begin{array}{l}\text { Percent of } \\
\text { Standard }\end{array}$ \\
\hline $\begin{array}{l}\text { Opposite Richland } \\
\text { (Holkirk Ranch) }\end{array}$ & 145 & 0.0130 & 0.0003 & 0.0039 & 7.8 \\
\hline $\begin{array}{l}\text { Opposite N. Richland } \\
\text { (Gillum Ranch) }\end{array}$ & 121 & 0.0138 & 0.0009 & 0.0040 & 8.0 \\
\hline $\begin{array}{l}\text { Opposite } 300 \text { Area } \\
\text { (Sullivan Ranch) }\end{array}$ & 100 & 0.0110 & 0.0008 & 0.0034 & 6.8 \\
\hline
\end{tabular}

WATER

Columbia River

The Columbia River from Grand Coulee Dam to the Washington-Oregon border, which includes the Hanford reach, has been designated as Class A or excellent by the Washington State Department of Ecology. This designation requires that industrial uses of the river be compatible with substantially all water needs including sanitary water, recreation, and wildlife. Numerous routine samples were collected from the river to measure the effect of Hanford operations on the existing radiological, chemical, biological, and physical status of the river water. The Columbia River is a source of potable water for Hanford personnel and for the Tri-City populace directly downstream of the Hanford site. Also the river below Hanford is extensively used for recreation as well as a source of irrigation water for the Ringold and Riverview farming areas.

\section{Radiological Evaluation}

Samples of Columbia River water were obtained from Vernita Bridge, 100-B, Hanford powerline, 300 Area, and Richland, Since the shutdown of the last once-through cooling production reactor in January 1971, levels of specific radionuclides in river water have generally become undetectable with routine. analytical methods. Table 5 is a summary of the routine water data obtained 
TABLE 5. Routine Analysis of Columbia River Water

\begin{tabular}{|c|c|c|c|c|c|c|c|c|c|c|}
\hline \multirow[b]{2}{*}{ Analysis } & \multirow[b]{2}{*}{$\begin{array}{l}\text { Analytical } \\
\text { Limit }\end{array}$} & \multicolumn{4}{|c|}{ Upstream of Hanford ${ }^{(b)}$} & \multicolumn{4}{|c|}{ Dównstream of Hanford $(c)$} & \multirow[b]{2}{*}{$\begin{array}{l}\text { ERDA 0524 (e) } \\
\text { Standards }\end{array}$} \\
\hline & & $\begin{array}{l}\text { No. of } \\
\text { Samples }\end{array}$ & $\begin{array}{l}\text { Maximum } \\
\text { Observed }\end{array}$ & $\begin{array}{l}\text { Minimum } \\
\text { Observed }\end{array}$ & $\begin{array}{l}\text { Annual }(\mathrm{d}) \\
\text { Average }\end{array}$ & $\begin{array}{l}\text { No. of } \\
\text { Samples }\end{array}$ & $\begin{array}{l}\text { Maximum } \\
\text { Observed }\end{array}$ & $\begin{array}{l}\text { Minimum } \\
\text { Observed }\end{array}$ & $\begin{array}{l}\text { Annual } \\
\text { Average } \\
\end{array}$ & \\
\hline Alpha & 0.23 & 12 & 0.59 & * & $:<0.27$ & 12 & 0.83 & 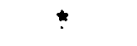 & $<0.34$ & 30 \\
\hline $\mathrm{H}-3$ & 360 & 12 & 860 & $\star$ & $<370$ & 11 & 940 & $\star$ & $<454$ & $3,000,000$ \\
\hline 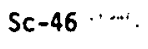 & $\cdots 30$ & 12 & * & $*$ & $*$ & 51 & $\star$ & * & $\star$ & 40,000 \\
\hline $\mathrm{Cr}-5 \mathrm{l}$ & 360 & $12^{\circ}$ & $\star$ & $\star$ & $\star$ & 51 & $\star$ & * & * & $2,000,000$ \\
\hline $\mathrm{C}_{0}-60$ & 24 & 12 & $\star$ & $\star$ & * & 51 & * & * & * & 30,000 \\
\hline $2 n-65$ & 50 & 12 & $\star$ & * & * & 51 & 62 & * & $<3.6$ & 100,000 \\
\hline $5 r-90$ & 0.04 & 12 & 0.76 & $0.14:$ & $0.35 \pm 0.40$ & 12 & 1.0 & $0.09 n$ & $0.46 \pm 0.59$ & 300 \\
\hline C5-137 & 26 & 12 & * & * & $\star$ & 51 & * & * & * & 20,000 \\
\hline$P u-239$ & 0.02 & 2 & $0.04^{\circ}$ & $\star$ & $<0.03$ & 2 & 0.02 & * & $<0.02$ & 5,000 \\
\hline
\end{tabular}

- Less than analytical limit.

(a) $10-9 \mu \mathrm{Ci} / \mathrm{ml}=1 \cdot \mathrm{pCi} / 1$

(b) Upstream samples were obtained at Vernita Bridge (weekly grab samples) and at 100-B (cumulative sample).

(c) Downstream samplès were obtained from the Richland sanitary water pumping dock (cumulative sample).

(d) Annual average \pm 2 sample standard deviations shown if all analyses were positive. 0therwise, a less-than number was calculated from the results, including less-than values.

(e) EROA 0524 standards only apply to concentrations in the environment in excess of naturally occurring or fallout radioactivity.

during 1975. The alpha measurements are an approximation of the naturally occurring uranium in the river. The observed values of ${ }^{90} \mathrm{Sr}$ and ${ }^{23.9} \mathrm{Pu}$ are are attributed to fallout since concentrations measured upstream of Hanford operations did not significantly differ from concentrations measured downstream. The tritium concentrations are due to fallout with approximately $10 \mathrm{pCl} / \ell$ due to naturally occurring tritium. A positive ${ }^{65} \mathrm{Zn}$ concentration was reported and is attributed to expected analytical variability in counting low-level environmental samples, not to Hanford operations. No other radionuclides were detected.

During 1975 an up-river filter-resin sampler 5 was installed at Priest Rapids to ascertain the types and amounts of radionuclides that exist in the Columbia River before it reaches the Hanford site. The data obtained from this sampler are presented in Table 6 and reflect existing quantities of naturally occurring or fallout related radionuclides. The data obtained from the downriver sampler (Table 7), located at the 300 Area, are compared to the upstream data to determine the impact of past or present Hanford operations on the Columbia River water quality. During 1975, radioactivity due to 


\section{TABLE 6. Concentration of Radionuclides in the Columbia River at Priest Rapids $(a, b)$}

\begin{tabular}{|c|c|c|c|c|c|c|c|c|c|c|c|}
\hline \multirow[b]{3}{*}{ Radionuclide } & \multicolumn{11}{|c|}{ Concentration $\left(10^{-9}{ }_{\mu} \mathrm{Ci} / \mathrm{ml}\right)$} \\
\hline & \multirow[b]{2}{*}{$\begin{array}{c}\text { Detection } \\
\text { Limit }\end{array}$} & \multirow[b]{2}{*}{$\begin{array}{l}\text { No. of (b) } \\
\text { Samples }\end{array}$} & \multicolumn{3}{|c|}{ Soluble } & \multicolumn{3}{|c|}{ Particulate } & Total & \multirow[b]{2}{*}{$\begin{array}{l}\text { ERDA } 0524^{(d)} \\
\text { Standard }\end{array}$} & \multirow[b]{2}{*}{$\begin{array}{l}\text { Percent of }(\mathrm{e}) \\
\text { Standard }\end{array}$} \\
\hline & & & $\begin{array}{l}\text { Maximum } \\
\text { Observed }\end{array}$ & $\begin{array}{l}\text { Minimum } \\
\text { Observed }\end{array}$ & $\begin{array}{l}\text { Annual }(\mathrm{c}) \\
\text { Average }\end{array}$ & $\begin{array}{l}\text { Maximum } \\
\text { Observed }\end{array}$ & $\begin{array}{l}\text { Minimum } \\
\text { Observed }\end{array}$ & $\begin{array}{l}\text { Annual }^{(\mathrm{c})} \\
\text { Average }\end{array}$ & $\begin{array}{l}\text { Annual }(c) \\
\text { Average }\end{array}$ & & \\
\hline $\begin{array}{c}K-40 \\
M n-54 \\
C o-60 \\
Z n-65 \\
\text { ZrNb-95 } \\
R u-106 \\
C s-137 \\
\text { Eu-152 } \\
\text { Ra-226 } \\
\text { Th-228 }\end{array}$ & $\begin{array}{l}0.009 \\
0.014 \\
0.0005 \\
0.005 \\
0.005 \\
0.005 \\
0.005 \\
0.02 \\
0.002 \\
0.0005\end{array}$ & $\begin{array}{l}6 \\
6 \\
6 \\
6 \\
6 \\
6 \\
6 \\
6 \\
6 \\
6\end{array}$ & $\begin{array}{l}0.69 \\
\star \\
0.0032 \\
\star \\
\star \\
0.06 \\
\star \\
\star \\
0.04 \\
0.004\end{array}$ & $\begin{array}{l}0.32 \\
\star \\
\star \\
\star \\
\star \\
0.04 \\
\star \\
\star \\
0.01 \\
0.001\end{array}$ & $\begin{array}{c}0.49 \pm 0.28 \\
\star \\
0.0009 \\
\star \\
\star \\
0.05 \pm 0.008 \\
\star \\
\star \\
0.02 \pm 0.03 \\
0.003 \pm 0.002\end{array}$ & $\begin{array}{l}0.02 \\
\star \\
\star \\
\star \\
\star \\
0.007 \\
\star \\
\star \\
0.004 \\
0.002\end{array}$ & $\begin{array}{l}\star \\
\star \\
\star \\
\star \\
\star \\
\star \\
0.0020\end{array}$ & $\begin{array}{c}<0.02 \\
\star \\
\star \\
\star \\
<0.005 \\
\star \\
\star \\
0.002 \pm 0.002 \\
<0.001\end{array}$ & $\begin{array}{c}<0.51 \\
\star \\
<0.007 \\
\star \\
\star \\
<0.06 \\
\star \\
\star \\
0.024 \pm 0.0 \\
<0.004\end{array}$ & $\begin{array}{r}- \\
100,000 \\
30,000 \\
100,000 \\
60,000 \\
10,000 \\
20,000 \\
60,000 \\
023 \quad 30 \\
1,000\end{array}$ & $\begin{array}{c}- \\
- \\
<3 \times 10^{-5} \\
- \\
- \\
<6 \times 10^{-4} \\
- \\
- \\
8 \times 10^{-2} \\
<4 \times 10^{-4}\end{array}$ \\
\hline
\end{tabular}

* Less than detection limit.

(a) Samples collected with a filter-ion exchange sampler. developed by the radiological chemistry group at Battelle. Filters and resin counted directly after collection with a high sensitivity multi-dimensional gamma ray spectrometer.

(b) Sample collection began in October and ran through December.

(c) Annual average \pm 2 sample standard deviation shown if all analyses were positive. 0therwise, a less-than number was calculated from the results, including less-than values.

(d) ERDA 0524 standards only apply to concentrations in excess of naturally occurring or fallout radioactivity.

(e) K-40, Ra-226, Th-228, occur naturally. Co-60 and Ru-106 are due to fallout.

\section{TABLE 7. Concentration of Radionuclides in the Columbia River at the 300 Area (a)}

\begin{tabular}{|c|c|c|c|c|c|c|c|c|c|c|c|}
\hline \multirow[b]{3}{*}{ Radionuclide } & \multicolumn{11}{|c|}{ Concentration $\left(10^{-9}{ }_{\mu} \mathrm{Ci} / \mathrm{ml}\right)$} \\
\hline & \multirow[b]{2}{*}{$\begin{array}{c}\text { Detection } \\
\text { Limit } \\
\end{array}$} & \multirow[b]{2}{*}{$\begin{array}{l}\text { No. of } \\
\text { Samples }\end{array}$} & \multicolumn{3}{|c|}{ Soluble } & \multicolumn{3}{|c|}{ Particulate } & Total & \multirow[b]{2}{*}{$\begin{array}{l}\text { ERDA } 0524(\mathrm{c}) \\
\text { Standard }\end{array}$} & \multirow[b]{2}{*}{$\begin{array}{l}\text { Percent of of } \\
\text { Standard }\end{array}$} \\
\hline & & & $\begin{array}{l}\text { Maximum } \\
\text { Observed }\end{array}$ & $\begin{array}{c}\text { Minimum } \\
\text { d Observed } \\
\end{array}$ & $\begin{array}{l}\text { Annua (b) } \\
\text { Average }\end{array}$ & $\begin{array}{l}\text { Maximum } \\
\text { Observed }\end{array}$ & $\begin{array}{l}\text { Minimum } \\
\text { Observed }\end{array}$ & $\begin{array}{l}\text { Annual } \\
\text { Average } \\
\text { Averate }\end{array}$ & $\begin{array}{l}T_{\text {Annual }}(\mathrm{D}) \\
\text { Average }\end{array}$ & & \\
\hline $\begin{array}{r}K-40 \\
M n-54 \\
\text { Co-60 } \\
2 n-65 \\
\text { ZrNb-95 } \\
R u-106\end{array}$ & $\begin{array}{l}0.009 \\
0.014 \\
0.0005 \\
0.005 \\
0.005 \\
0.005\end{array}$ & $\begin{array}{l}19 \\
19 \\
19 \\
19 \\
19 \\
19\end{array}$ & $\begin{array}{l}0.70 \\
0.05 \\
0.02 \\
\vdots \\
0.07 \\
0.16\end{array}$ & $\begin{array}{l}0.22 \\
\star \\
0.004 \\
\star \\
0.06\end{array}$ & $\begin{array}{c}0.50 \pm 0.28 \\
<0.014 \\
0.009 \pm 0.007 \\
\star \\
<0.004 \\
0.08 \pm 0.05\end{array}$ & $\begin{array}{l}0.11 \\
0.54 \\
0.11 \\
0.09 \\
0.38 \\
0.07\end{array}$ & $\begin{array}{l}\stackrel{\star}{\star} \\
\stackrel{0}{0.002} \\
\star \\
\star \\
0.002\end{array}$ & $\begin{array}{l}<0.02 \\
<0.07 \\
0.02 \pm 0.05 \\
<0.01 \\
<0.037 \\
0.01 \pm 0.03\end{array}$ & $\begin{array}{l}<0.51 \\
<0.054 \\
0.02 \pm 0.05 \\
<0.01 \\
<0.06 \\
0.10 \pm 0.08\end{array}$ & $\begin{array}{r}100,000 \\
30,000 \\
100,000 \\
60,000 \\
10,000\end{array}$ & $\begin{array}{l}<5.4 \times 10^{-5} \\
<2.3 \times 10^{-4} \\
<1.0 \times 10^{-5} \\
<1.0 \times 10^{-4} \\
<1.8 \times 10^{-3}\end{array}$ \\
\hline $\begin{array}{r}I-1.31 \\
C s-134\end{array}$ & $\begin{array}{l}n .01 \\
0.0005\end{array}$ & $\begin{array}{l}17 \\
19\end{array}$ & 0.0 & * & $<0.006$ & $\stackrel{*}{0.03}$ & 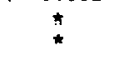 & $<0^{*} 003$ & $<0.009$ & $\begin{array}{r}300 \\
9,000\end{array}$ & $<1.0 \times 10^{-\mathrm{L}}$ \\
\hline & & 19 & & $\therefore$ & & & 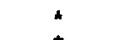 & $<0$. & & & \\
\hline $\begin{array}{l}\text { BaLa- } \\
\text { Eu- }\end{array}$ & 005 & $\begin{array}{l}19 \\
19\end{array}$ & $\stackrel{0.2}{\star}$ & & & 0. & $\star$ & $<0$ & $<0.0$ & & $<5.0 \times 10^{-5}$ \\
\hline Eu-1 & $\begin{array}{l}0.02 \\
0.002\end{array}$ & $\begin{array}{l}19 \\
19\end{array}$ & 0.06 & & ${ }^{*} 03$ & & & & $t$ & 60,000 & \\
\hline $\begin{array}{l}\text { Ra-226 } \\
\text { Th-228 }\end{array}$ & $\begin{array}{l}0.002 \\
0.0005\end{array}$ & 19 & $\begin{array}{l}0.06 \\
0.04\end{array}$ & & $\begin{array}{l}<0.03 \\
<0.005\end{array}$ & $\begin{array}{l}0.06 \\
0.001\end{array}$ & & $\begin{array}{l}<0.006 \\
<0.002\end{array}$ & $\begin{array}{l}<0.04 \\
<0.007\end{array}$ & $\begin{array}{r}30 \\
1,000\end{array}$ & $\begin{array}{l}<1.3 \times 10^{-1} \\
<7.0 \times 10^{-4}\end{array}$ \\
\hline
\end{tabular}

* Less than detection limit.

(a) Samples collected with a filter-ion exchange sampler developed by the radiological chemistry group at Battelle. Filters and resin counted directly after collection with a high sensitivity multi-dinensional gamma ray spectrometer.

(b) Annual average \pm 2 sample standard deviation shown if all analyses were positive. Otherwise, a less-than number was calculated from the result.s, including less-than values.

(c) ERDA 0524 standards only apply to concentrations in excess of naturally occurring or fallout radioactivity. 
Hanford operations, was observed at the downstream sampler and is attributed to resuspension of sediments into which radioactivity from past once-through cooling production reactor operation is sorbed and to the annual maintenance outage at $\mathrm{N}$ Reactor in late May and early June. Quantities of radionuclides observed during this time were all less than 1\% of the ERDAM 0524 concentration guides. Ba-La-140 was detected only during the outage. A large majority of the particulate ${ }^{54} \mathrm{Mn},{ }^{60} \mathrm{Co},{ }^{65} \mathrm{Zn}$, and ${ }^{95} \mathrm{ZrNb}$ concentrations are attributable to resuspension of river sediment. The other radionuclides listed are primarily dissolved in the river water and are probably due to both fallout and current Hanford operations. All of the annual measured concentrations were less than $0.2 \%$ of the ERDAM 0524 concentration guides. A synopsis of the filter-resin sampling system is given in Appendix $A$.

\section{Nonradiological Evaluation}

Measurements of water quality parameters other than radioactivity are routinely made on Columbia River water in order to:

- Detect any impact of the Hanford waste disposal practices on river water quality.

- Demonstrate continued compliance with Washington State Water Quality ${ }^{2}$ Standards for the Columbia River and Public Health Service 6 recommendations for sources of drinking water.

Physical and chemical parameters measured during 1975 included pH', turbidity, dissolved oxygen, nitrate ion and temperature. Biological measurements included coliform orqanisms and BOD. Enterococci measurements were made to clarify the types of coliforms present. The parameters most likely to be affected by Hanford operations are temperature and nitrate ion. Figure 5 shows the average monthly temperature measured at Vernita Bridge and at Richland during 1975. Some of the temperature difference is due to naturai causes' and some is attributable to operations on the Hanford site. The greatest observed difference occurs during the summer months when $N$ reactor was not in operation. The annual average temperature and $95 \%$ confidence interval for Priest Rapids Dam and Richland during 1975 were $10.7 \pm 11.7$ and $11.1 \pm 11.7^{\circ} \mathrm{C}$, respectively, based on 365 daily measurements. Figure 6 illustrates the daily variation of river temperature with season and flowrate during 1975. 


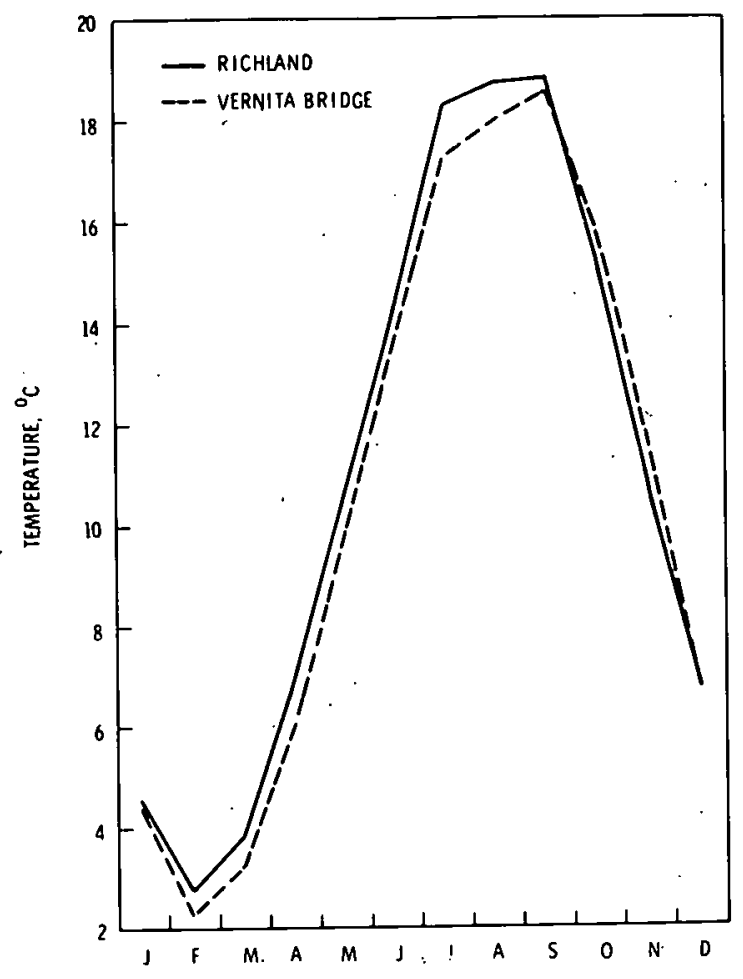

FIGURE 5. Columbia River Monthly Temperature at Richland and Priest Rapids Dam for 1975

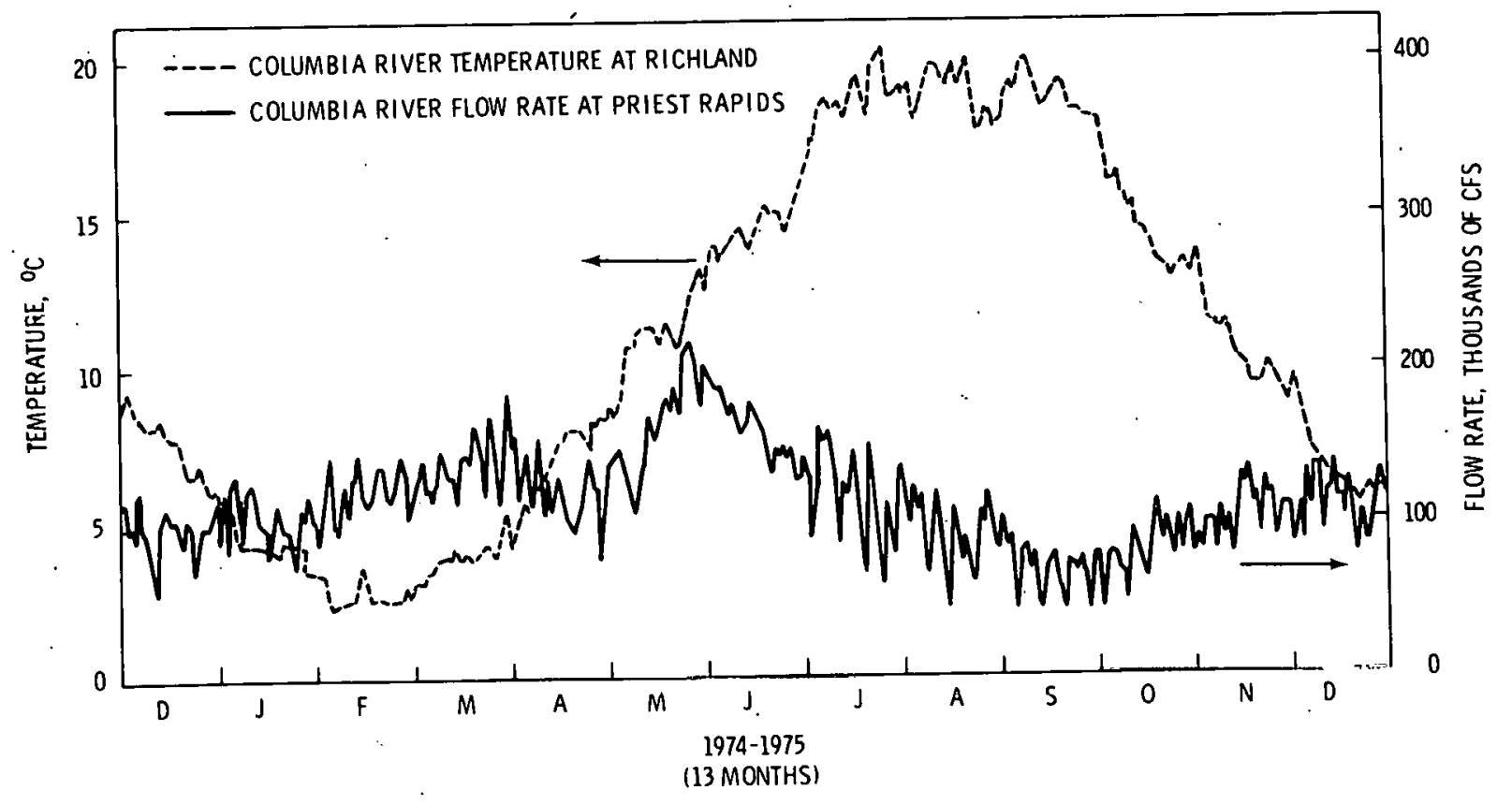

FIGURE 6. Columbia River Daily Flow and Temperature During 1975 
Results of biological analyses of Columbia River water during 1975 are shown in Table 8 . The data indicate an increase of coliform organisms, enterococci, and BOD between Vernita Bridge and Richland. These apparent increases are believed to be the result of drainage from farm activities and wildlife, for the Hanford stretch of the river serves as a refuge for large populations of waterfowl.

Results of chemical analyses are shown in Table 9. Nitrates, pH, turbidity, and dissolved oxygen were measured at both Vernita Bridge and Richland. The measurements observed were similar at both locations and well within applicable standards adopted by the State of. Washington for Class A rivers. 2 Average nitrate concentrations were less than $0.6 \%$ of the $45 \mathrm{ppm}$ standard, a $40 \%$ decrease from 1974 values. Average pH for 1975 was 8.0 at Vernita

TABLE 8. Columbia River Biological Analyses - 1975

\begin{tabular}{|c|c|c|c|c|c|c|c|c|c|c|}
\hline \multirow[b]{2}{*}{ Analysis } & \multirow[b]{2}{*}{ Units } & \multirow[b]{2}{*}{ Standard } & \multicolumn{4}{|c|}{ Vernita } & \multicolumn{4}{|c|}{ Richland } \\
\hline & & & $\begin{array}{l}\text { No. of } \\
\text { Samples }\end{array}$ & $\operatorname{Max}$ & Min & Average & $\begin{array}{l}\text { No. of } \\
\text { Samples }\end{array}$ & Max & Min & Average \\
\hline Coliform & No. $/ 100 \mathrm{ml}$ & 240 & 8 & 64 & 12 & $30 \pm 33$. & 9 & 56 & 8 & $36 \pm 35$ \\
\hline Enterococci & No. $/ 100 \mathrm{ml}$ & - & 8 & 26 & 4 & $14 \pm 17$ & 9 & 51 & 3 & $27 \pm 29$ \\
\hline$B O D$ & $\mathrm{mg} / \mathrm{l}$ & - & 8 & 4.5 & 3.0 & $3.9 \pm 7.0$ & 9 & 5.8 & 2.4 & $4.0 \leq 1.8$ \\
\hline
\end{tabular}

TABLE 9. Columbia River Chemical Analyses - 1975

\begin{tabular}{|c|c|c|c|c|c|c|c|c|c|c|}
\hline \multirow[b]{2}{*}{ Analys is } & \multirow[b]{2}{*}{ Units } & \multirow[b]{2}{*}{ Standard } & \multicolumn{4}{|c|}{ Vernita } & \multicolumn{4}{|c|}{ Richland (a) } \\
\hline & & & $\begin{array}{l}\text { No. of } \\
\text { Samples }\end{array}$ & Maximum & Minimum & $\begin{array}{l}\text { Annual }(\mathrm{b}) \\
\text { Average }\end{array}$ & $\begin{array}{l}\text { No. of } \\
\text { Samples }\end{array}$ & Maximum & Minimum & $\begin{array}{l}\text { Annual }(\mathrm{b}) \\
\text { Average }\end{array}$ \\
\hline $\mathrm{NO}_{3}$ & $\mathrm{ppm}$ & 45 & 51 & 0.63 & & $<0.25$ & & 0.54 & $\star$ & \\
\hline $\mathrm{pH}$ & & 6.5 to 8.5 & 48 & 8.5 & 7.6 & $8.0 \pm 0.78$ & 247 & 8.8 & 7.4 & $8.0 \pm 0.7$ \\
\hline Turbidity & $\mathrm{JTU}^{(\mathrm{c})}$ & $5+B k g$ & 41 & 6.5 & 0,4 & $1.7 \pm 2.3$ & 210 & 6.0 & 0.6 & $1.7 \pm 1.8$ \\
\hline Dissolved $\mathrm{O}_{2}$ & $\mathrm{mg} / \mathrm{l}$ & $8.0 \mathrm{~min}$ & 38 & 13.9 & 9.5 & $11.7 \pm 2.4$ & 218 & 14.1 & 8.6 & $11.8 \pm 2.5$ \\
\hline
\end{tabular}

\footnotetext{
* Less than detection limit. Detection limit would be a tabled value of 0.1 for $\mathrm{NO}_{3}$ analysis.

(a) $\mathrm{pH}$, turbidity and dissolved $\mathrm{O}_{2}$ samples obtained from 300 Area sanitary water pumping dock.

(b) Average \pm 2 sample standard deviations shown if all analyses were positive. 0therwise a less-than number was calculated from all results, including less-than detectable values.

(c) Jackson turbidity units.
} 
- Bridge and Richland, equivalent to 1974 values and well within the 6.5 to 8.5 standard. The turbidity standard is based on an increase of 5 JTU (Jackson turbidity units) above background. Since no observed differences were apparent between Vernita Bridge and Richland, the tabled values were assumed to represent background. Average values for dissolved oxygen in the river were well above the minimum standard of $8 \mathrm{mg} / \ell$. The averages observed at Vernita Bridge and Richland during 1975 were $11.7 \mathrm{mg} / \ell$ and $11.8 \mathrm{mg} / \mathrm{l}$, respectively an increase of approximately 10\% over 1974 values. In summary, the Hanford site has had no measurable chemical impact on the Columbia River in 1975 and the river water quality is well within Washington State standards.

\section{Sanitary Water}

The city of Richland is the first community below the Hanford Reservation that uses the Columbia River as a source of drinking water. BNW collects a cumulative ( $30 \mathrm{ml}$ every 30 minutes) sanitary water sample at the Richland treatment plant for radiological analyses, and HEHF routinely collects grab samples for analyses of bacteriological and chemical purity.

\section{Radiological Evaluation}

In addition to the samples of river water collected at Vernita Bridge, 100-B, Hanford powerline, 300 Area, and Richland, cumulative sanitary water sampling was conducted at the Richland treatment plant. The samples collected were analyzed on a weekly basis by gross beta and gross alpha analyses and by gamma spectrometry of a monthly composite of weekly samples. The results of these analyses for 1975 are shown in Table 10. The gross alpha measurement is an approximation of the naturally occurring uranium in the river. Strontium-90 was observed on several occasions and was attributed to fallout. No other radionuclides were observed. Specific analyses for tritium in drinking water was not done because the levels would be the same as observed in the river water (Table 5), since tritium cannot be removed by sanitary water treatment facilities. The source of tritium is primarily fallout with a small amount occurring naturally. 
TABLE 10. Radiological and Chemical Analyses of Drinking Water - 1975(a).

Richland

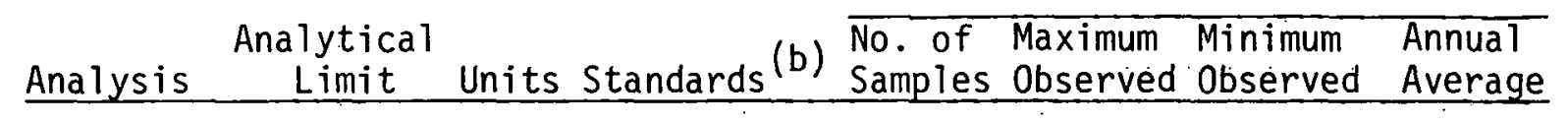

Radiological

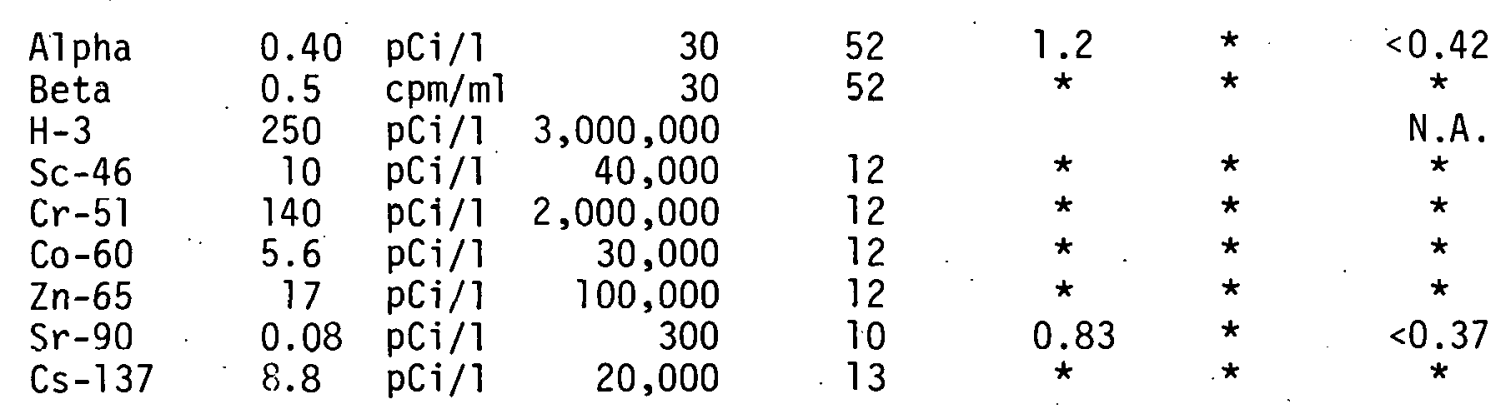

Chemical
$\mathrm{NO}_{3}$
$0.1 \cdot \mathrm{ppm}$
45
52
2.8
$<0.46$

* Less than analytir.al limit.

N.A. Not analyzed.

(a) Average plus or minus two sample standard deviations shown if all analyses were positive. Otherwise, a less-than number was calculated trom all results, including less-than numbers.

(b) Radiological standards obtalned from ERDA 0524 and apply only to concentrations in excess of natural or fallout activity. Nitrate standard was promulgated by the Environmental Protection Agency.

Nonradiological Evaluation

Grab samples were collected from the Richland sanitary water system during 1975 for analyses of chemical and bacteriological purity. All bacteriological tests were negative and thus in cumpliance with the standard of no detectable coliform bacteria in potable water. Chemical analysis for nitrate was done on a weekly basis during 1975 (Table 10). The annual average nitrate concentration was about $1 \%$ of the EPA drinking water standard of $45 \mathrm{ppm}^{3}$ 
Groundwater

An extensive groundwater monitoring program continued to demonstrate no measurable effect on Columbia River quality from low-level wastes released to ground disposal sites within the Hanford plant boundaries. The data from this program is documented separately, the most recent report in this series being BNWL-1970.8 A remote possibility exists that radioactive or process materials could penetrate to confined aquifers underlying the Pasco Basin. Several farm wells penetrating these confined aquifers on the east side of the Columbia River (Figure 8 ) are routinely sampled for tritium and nitrate ion. The data are not definitive, since contamination from the surface by nitrate from fertilizers and tritium from recent precipitation can also occur. Table 11 shows data from these wells for 1975.

TABLE 11. Groundwater Analyses from Wells in the Vicinity of Hanford - 1975

\begin{tabular}{|c|c|c|c|c|c|c|c|}
\hline \multirow{2}{*}{\multicolumn{2}{|c|}{$\begin{array}{r}\text { Concentration Guide } \\
\text { Analytical Limit } \\
\text { (c) }\end{array}$}} & \multicolumn{3}{|c|}{${ }^{3} \mathrm{H}\left(10^{-9} \mu \mathrm{Ci} / \mathrm{ml}\right)^{(\mathrm{a})}$} & \multicolumn{3}{|c|}{$\mathrm{NO}_{3}(\mathrm{ppm})$} \\
\hline & & & $\begin{array}{r}, 000,0 \\
\sim 800\end{array}$ & & & $\begin{array}{r}45 \\
0.5\end{array}$ & \\
\hline Location & Samples & Max & Min & Ave & Max. & Min & Ave \\
\hline Webber & 2 & 1200 & $<500$ & $<850$ & * & $\star$ & $\star$ \\
\hline$W-15$ & 2 & $<930$ & $<700$ & $<815$ & * & $\star$ & $\star$ \\
\hline Vail & 2 & $<900$ & 700 & $<800$ & $\star$ & $\star$ & $\star$ \\
\hline Allison Manor & 2 & $<1300$ & $<500$ & $<900$ & * & * & $\star$ \\
\hline $\begin{array}{l}\text { White Bluffs } \\
\text { Association }\end{array}$ & 2 & $<870$ & $<500$ & $<685$ & * & $\star$ & $\star$ \\
\hline
\end{tabular}

* Less than the analytical limit.

(a) $10^{-9} \mu \mathrm{Ci} / \mathrm{mi}=1 \mathrm{pCi} / 1$.

(b) ERDA 0524 Concentrations Guides only apply to concentrations in excess of naturally occurring or fallout levels.

(c) Average analytical limit shown for tritium was calculated from. the detection limit of each analys is. 


\section{FOODSTUFF}

Foodstuffs, including milk, meat, chicken, eggs and leafy vegetables were collected from local farms and commercial outlets, and analyzed for gamma emitting radionuclides and ${ }^{90} \mathrm{Sr}$ (Tables 12 through 14 ). Since Riverview farming area is irrigated with Columbia River water after it has passed through the Hanford site, samples of each foodstuff were obtained from this area. The data were used to evaluate the approximate dose received from eating these particular foods which comprise a significant fraction of the typical diet.

Potassium-40, a naturally occurring radionuclide, contributed the majority of the radioactivity measured in all samples. Strontium- 90 was measured in most foodstuff samples and the observed levels are attributed to fallout,

TABLE 12. Concentrations of Radionuclides in Milk - 1975.

\begin{tabular}{|c|c|c|c|c|c|c|c|c|c|c|}
\hline \multirow{3}{*}{\multicolumn{2}{|c|}{$\begin{array}{l}\text { Concentration Guide } \\
\text { Analytical Limit }\end{array}$}} & \multicolumn{9}{|c|}{ Concentration $\left(10^{-9}{ }_{\mu} \mathrm{Ci} / \mathrm{ml}\right)^{(\mathrm{a})}$} \\
\hline & & \multicolumn{3}{|c|}{$K-40$} & \multirow{2}{*}{\multicolumn{3}{|c|}{$\begin{array}{c}\frac{5 r-90}{200.0} \\
0.73 \\
\text { esults }(c)^{(d)} \\
\end{array}$}} & \multirow{2}{*}{\multicolumn{3}{|c|}{$\begin{array}{r}\frac{[-13]}{100.0} \\
0.40\end{array}$}} \\
\hline & & . & 560 & Sample & & & & & & \\
\hline Location & $\begin{array}{l}\text { No. of } \\
\text { Samples }\end{array}$ & Max & Min & Average & Max & Min & Average & Max & Min & Average \\
\hline Riverview & 26 & 1200 & 720 & $880 \div 250$ & 3.2 & * & (1.8 & .41 & * & .40 \\
\hline Wahluke & 26 & 1200 & 780 & $970 \pm 220$ & 3.7 & 1.0 & $2.4 \pm 3.0$ & 0.42 & * & $<0.40$ \\
\hline Benton City \#3 & 27 & 120 & 630 & $980 \pm 250$ & 5.0 & * & $<3.6$ & 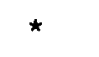 & * & * \\
\hline Benton City \#4 $(e)$ & 20 & 990 & * & $<820$ & 1.2 & 1.1 & $1.2 \pm 0.08$ & * & * & * \\
\hline Benton City \#5 $(\mathrm{e})$ & 6 & 1100 & * & $<880$ & & & $1.4^{(f)}$ & 0.57 & * & $<0.43$ \\
\hline Commercial Brand $\mathrm{H}$ & 14 & 1300 & 820 & 1000 & 5.0 & * & $<2$ & * & * & * \\
\hline Commercial Composite & 14 & 1200 & 130 & $960 \pm 210$ & 5.4 & * & $<2.6$ & 0.78 & * & $<0.43$ \\
\hline \multicolumn{11}{|c|}{$\begin{array}{l}\text { Less than detectable } \\
\text { (a) } 10^{-9} \mu C \mathrm{C} / \mathrm{ml}=1 \mathrm{pC} / / \ell \\
\text { (b) Strontium-90 and Iodine-131 concentration guides in milk were established by the Federal } \\
\text { Radiation Council. Potassium-40 is a naturally occurring radionuclide. } \\
\text { (c) The arithmetic mean } \pm 2 \text { sample standard deviations are tabled under the Average column if } \\
\text { positive results were observed for each analyses. Otherwise, a less-than value is calculated } \\
\text { from all the results, including less-than detectable values. } \\
\text { (d) Sr-90 analysis is performed quarterly. } \\
\text { (e) Benton City } 44 \text { source was discontinued } 10-1-75 \text {, Benton City, \#5 source was begun on } 10-23-75 \text {. } \\
\text { (f) Only one analysis. }\end{array}$} \\
\hline
\end{tabular}


TABLE 13. Concentrations of Radionuclides in Meat, Chicken, and Eggs - 1975

Concentration $\left(10^{-i}, \mu \mathrm{Ci} / \mathrm{gm}\right)$ wet weight ${ }^{(a)}$

\begin{tabular}{|c|c|c|c|c|c|c|c|c|c|c|c|c|c|}
\hline \multirow{2}{*}{$\begin{array}{l}\text { Sample } \\
\text { Location }\end{array}$} & \multirow{2}{*}{$\begin{array}{l}\text { No. of } \\
\text { Samples }\end{array}$} & \multicolumn{3}{|c|}{$K-40$} & \multicolumn{3}{|c|}{$Z n-65$} & \multicolumn{3}{|c|}{$S r-90$} & \multicolumn{3}{|c|}{ Cs -137} \\
\hline & & $\operatorname{Max}$ & Min. & Average & Max & Min & Average & Max & Min & Average & $\operatorname{Max}$ & Min & Average \\
\hline Meat & & & & & & & & & & & & & \\
\hline $\begin{array}{l}\text { Commercial } \\
\text { Riverview }\end{array}$ & $\begin{array}{r}13 \\
1\end{array}$ & 2.4 & 1.6 & $\begin{array}{c}2.0 \pm 0.7 \\
1.9\end{array}$ & 0.08 & * & $\stackrel{0.02}{*}$ & 0.007 & $\star$ & $\begin{array}{r}<0.002 \\
0.002\end{array}$ & * & * & 0.03 \\
\hline Chicken & & & & & & & & & & & & & \\
\hline $\begin{array}{l}\text { Commercial } \\
\text { Riverview }\end{array}$ & $\begin{array}{l}2 \\
4\end{array}$ & $\begin{array}{l}1.5 \\
2.0\end{array}$ & $\begin{array}{l}1.3 \\
1.1\end{array}$ & $\begin{array}{l}1.4 \pm 0.3 \\
1.6 \pm 0.8\end{array}$ & * & * & * & $\begin{array}{l}0.006 \\
0.01\end{array}$ & * & $\begin{array}{l}<0.004 \\
<0.005\end{array}$ & * & * & * \\
\hline Eggs & & & & & & & & $\cdot$ & & & & & \\
\hline $\begin{array}{l}\text { Commercial } \\
\text { Riverview }\end{array}$ & $\begin{array}{r}2 \\
13\end{array}$ & $\begin{array}{l}0.8 \\
1.1\end{array}$ & $\begin{array}{l}0.78 \\
0.64\end{array}$ & $\begin{array}{l}0.79 \pm 0.03 \\
0.92 \pm 0.23\end{array}$ & $\star$ & $\star$ & $\stackrel{\star}{\star}$ & $\begin{array}{l}0.003 \\
0.003\end{array}(b)$ & 0.001 & $\begin{array}{l}0.002 \pm 0.0014 \\
<0.001\end{array}$ & $\begin{array}{l}\star \\
\star\end{array}$ & * & * \\
\hline
\end{tabular}

* Less than detectable. Approximate detection limits would be: K-40,0.6; Zn-65,0.07; Sr-90,0.002; Cs-137, 0.04.

(a) $10^{-6} \mu \mathrm{Ci} / \mathrm{gm}=1 \mathrm{pCi} / \mathrm{gm}$. The arithmetic mean plus or minus two sample standard deviations, are tabled under the average column if positive results were observed for each analysis. Otherwise, a less-than value is calculated from all results, including the less-than values.

(b) Sr-90 analysis done on only 3 samples.

TABLE 14. "Concentrations of Radionuclides in Leafy VegetablesSpinach, Leaf Lettuce, Turnip Greens, Mustard Greens - 1975

Concentration $\left(10^{-} 6, \mu \mathrm{Ci} / \mathrm{gm}\right)$ Wet Weight $(\mathrm{a})$

\begin{tabular}{|c|c|c|c|c|c|c|c|c|}
\hline \multirow[b]{2}{*}{$\begin{array}{l}\text { Sample } \\
\text { Location }\end{array}$} & \multicolumn{4}{|c|}{$k-40^{(b)}$} & \multicolumn{4}{|c|}{$S r-90^{(b)}$} \\
\hline & $\begin{array}{l}\text { No. of } \\
\text { Samples }\end{array}$ & $\operatorname{Max}$ & Min & Average $^{(c)}$ & $\begin{array}{l}\text { No. of } \\
\text { Samples }\end{array}$ & Max & Min & Average \\
\hline Riverview & 4 & 3.3 & 2.1 & $2.6 \pm 1.0$ & 2 & 0.06 & 0.02 & 0.04 \\
\hline Benton City & 1 & & & 1.4 & 1 & & & 0.02 \\
\hline Commercial & 6 & 5.1 & 2.1 & $3.3 \pm 2.7$ & 2 & 0.03 & 0.004 & 0.02 \\
\hline $\begin{array}{l}\text { (a) } 10^{-} 6 \\
\text { (b) Detect } \\
\text { radion } \\
\text { (c) Averag }\end{array}$ & $\begin{array}{l}\text { gm }= \\
\text { limit } \\
\text { ides } \\
2 \text { samp }\end{array}$ & $\begin{array}{l}\mathrm{pCi} \\
\text { are }\end{array}$ & $k$ & deviat &, 0 & The & wer & no 0 \\
\hline
\end{tabular}


not to Hanford operations. In $10(i 8 \%)$ of 133 milk samples analyzed

131 I was reported and then at levels very near the environmental detection limit. No $131 \mathrm{I}$ was detected in air or river water samples, the oniy pathways of transport. Other isotopes were detected only occasionally and the levels only slightly above the detection limit of the analyses. To obtain absolute measurements with such low levels of radioactivity is extremely difficult; several of the tabled values may represent nothing more than the statistical variability of background.

In summary, most of the radioactivity measured in foodstuffs during 1975 was the result of naturally occurring ${ }^{40} \mathrm{~K}$ and ${ }^{90} \mathrm{Sr}$ due to fallout. Other radionuclides occasionally detected are believed to be due to worldwide fallout or the statistical variability of background.

WILDLIFE

Samples of wildlife, including gamebirds and fish were routinely collected from the Hanford environs and analyzed for levels of radioactivity. Table 15 lists the results obtained during 1975. Fish, usually whitefish, were collected monthly from the Columbia River and the composite analyzed. Gamebirds were collected along the Columbia River, primarily during hunting season. The radionuclide present in the qreatest quantity was $40 \mathrm{~K}$, a naturally occurring radionuclide. Cobalt-60, ${ }^{90} \mathrm{Sr}$, and ${ }^{137} \mathrm{Cs}$ were observed in several samples of fish. Strontium-90 was detected in 10 ducks and ${ }^{137} \mathrm{Cs}$ was detected in 2 ducks out of the 27 collected. Cesium-137 was observed in 4 out of 17 geese sampled and ${ }^{90} \mathrm{Sr}$ was observed in 4 out of 16 pheasants collected. All of the artificially produced radionucilides detected in the wildlife samples were detected at levels at or very near the respective environmental detection limits. The origin of the ${ }^{60} \mathrm{Co}$ activity is attributed to previous operation of the once-through cooling production reactors, as discussed under the Columbia River Section. Strontium-90 and ${ }^{137} \mathrm{Cs}$ activity are attributed to fallout. 
TABLE 15. Concentrations of Radionuclides in Muscle Tissue of Selected Wildlife Obtained from the Hanford Environs - 1975

$$
\text { Concentration }\left(10^{-6}{ }_{\mu} \mathrm{Ci} / \mathrm{gm}\right) \text { wet weight }(\mathrm{a}, \mathrm{b})
$$

\begin{tabular}{|c|c|c|c|c|c|c|c|c|c|c|c|c|c|}
\hline \multirow[b]{2}{*}{ Wildlife } & \multirow{2}{*}{$\begin{array}{l}\text { No. of } \\
\text { Samples }\end{array}$} & \multicolumn{3}{|c|}{$K-40$} & \multicolumn{3}{|c|}{$\mathrm{Co}-60$} & \multicolumn{3}{|c|}{$\mathrm{Sr}-90$} & \multicolumn{3}{|c|}{$C_{5}-137$} \\
\hline & & $\operatorname{Max}$ & Min & Average & $\operatorname{Max}$ & Min & Average & $\operatorname{Max}$ & Min & Average & $\overline{M a x}$ & Min & Average \\
\hline Whitefish & 9 & 4.2 & 2.8 & $4.0 \pm 4.8$ & 0.24 & * & $<0.1$ & 0.18 & * & $<0.03$ & 0.43 & * & $<0.13$ \\
\hline Ducks & 27 & 4.1 & $\star$ & $<3.12$ & * & * & $\star$ & 0.05 & * & $<0.01$ & 0.15 & * & $<0.05$ \\
\hline Geese & 17 & 3.5 & 2.0 & $3.12 \pm 3.4$ & * & * & * & - & - & - & 0.17 & * & $<0.12$ \\
\hline Pheasants & 16 & 3.8 & * & $<2.8$ & * & * & * & 0.08 & $\star$ & $<0.02$ & 0.1 & $\star$ & $<0.08$ \\
\hline
\end{tabular}

* Less than detectable. Tabled detection limits would be approximately: K-40, 2.0; Co-60, 0.12; Sr-90, 0.005; Cs $-137,0.1$.

- No specific analysis made.

(a) $10^{-6} \mu \mathrm{Ci} / \mathrm{gm}=1 \mathrm{pCi} / \mathrm{gm}$.

(b) Average plus or minus two sample standard deviations reported if all analyses were positive. Otherwise a less than value was calculated from all results, including less-than values.

Willapa Bay oysters were collected in 1975 and analyzed for ${ }^{6} 5 \mathrm{Zn}$ activity. Zinc-65 has a 245-day halflife and the observed decline of activity in oysters, as shown in Figure 7 , closely approximates the radioactive decay rate. The radioactive decay rate will result in a yearly loss of approximately $64 \%$ of the previous year's activity. Since early 1970, an approximate five-hundred-fold decrease in activity has occurred. 


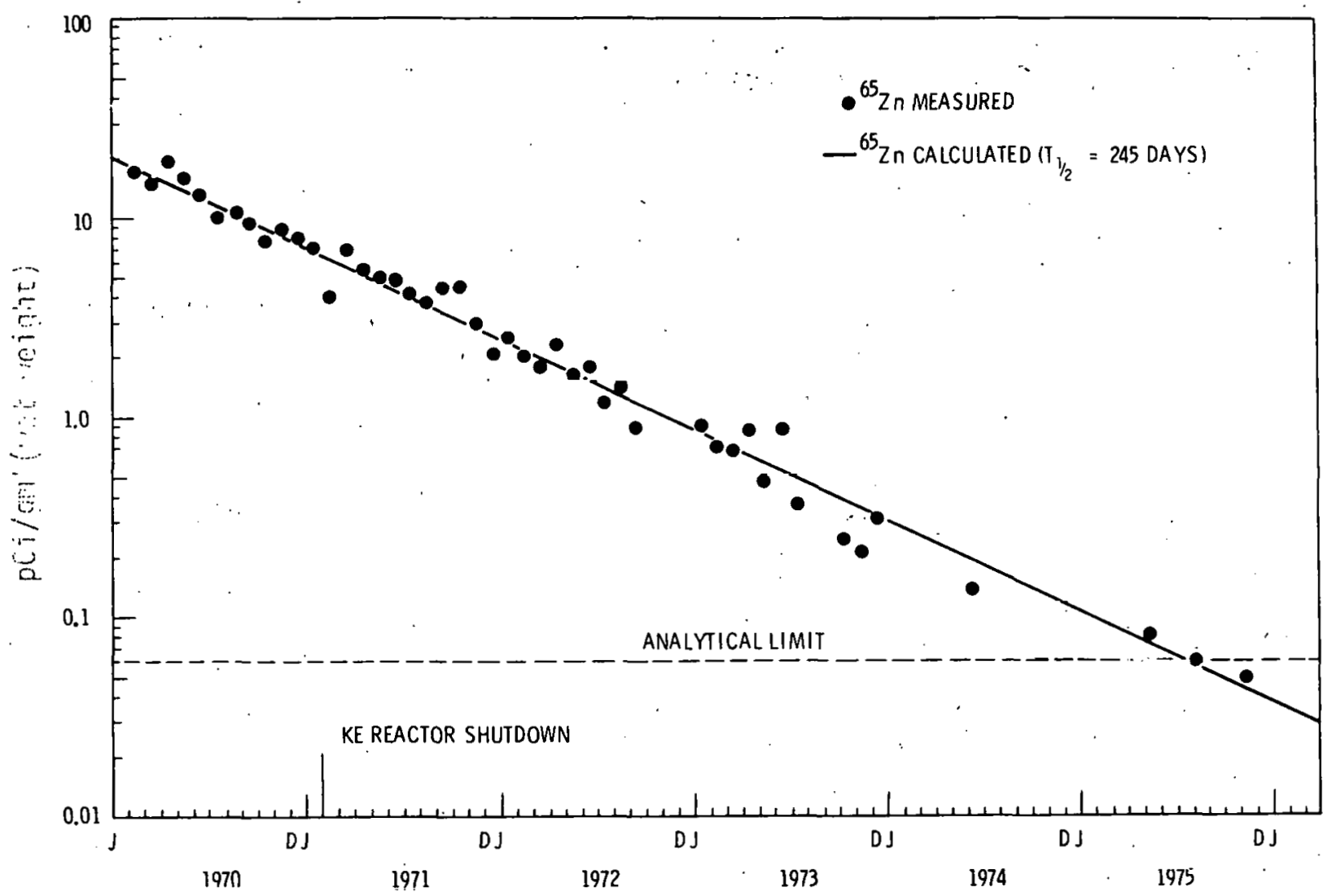

FIGURE 7. Zinc-65 Concentration in Willapa Bay Oysters During 1970 Through 1975

SOIL AND VEGETATION

Surface soil and perennial vegetation samples were collected froin 8 differ= ent locations during the summer of 1975 for the purpose of measuring the levels of radioactivity due to fallout and natural causes as well as to assess any potential buildup of radioactivity from Hanford operations. These locations are shown in rigure 8 and the results listed in Tables 16 and 17. Each soil sample represents the composite of five "plugs" of soil from an approximate $10 \mathrm{~m}^{2}$ area. Each plug was approximately 2.5 centimeters ( 1 inch) in depth and 10 centimeters ( 4 inches) in diameter. The vegetation samples were collected in the immediate vicinity of each soil sampling location and consisted of perennial vegetation, primarily the new growth from rabbit-brush plants. Both sets of samples were analyzed for. 


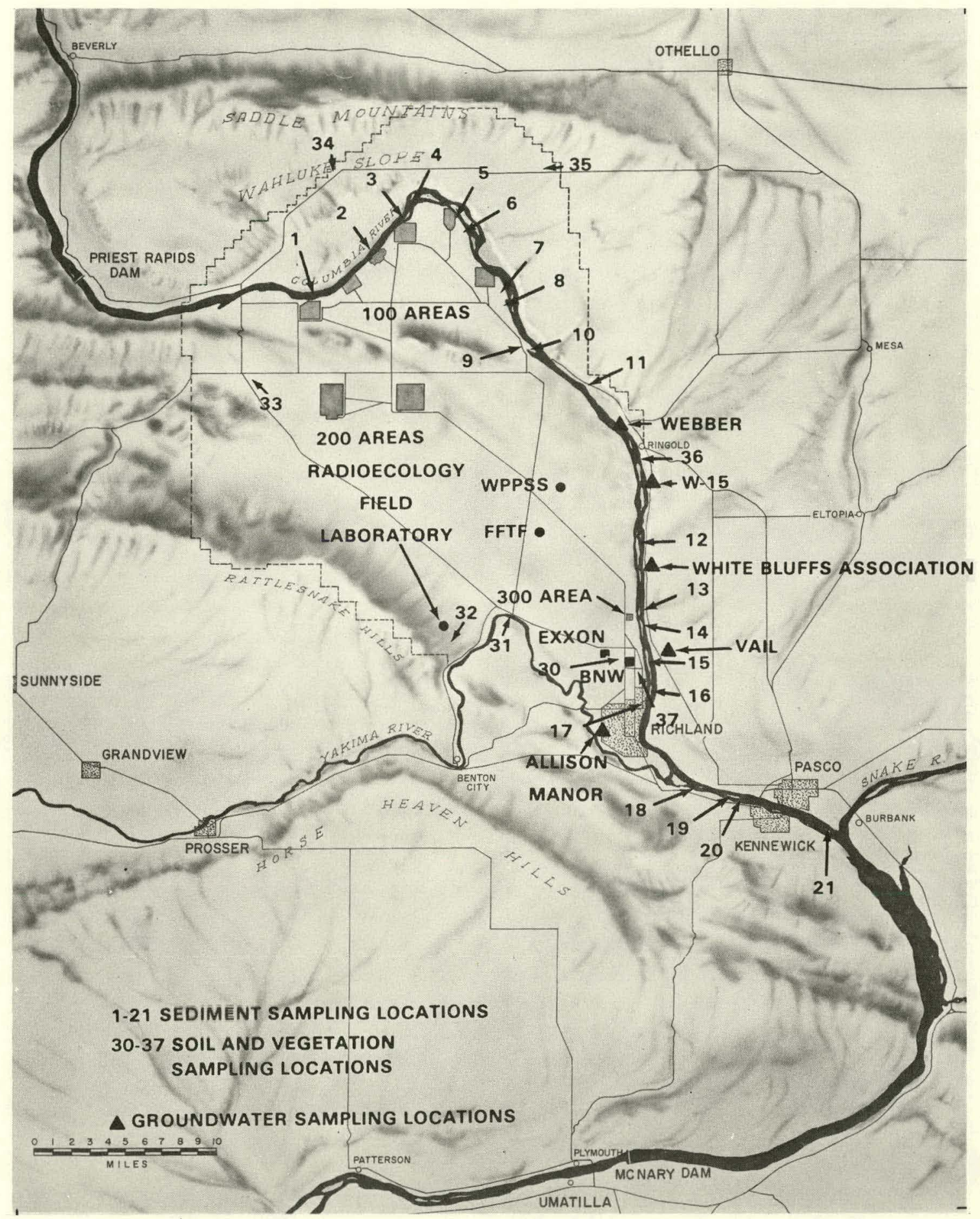

FIGURE 8. Soil, Sediment, and Groundwater Sampling Locations in the Vicinity of the Hanford Site. 
TABLE 16. Concentrations of Radionuclides in Perimeter Soil Samples - 1975

Units of $10^{-6} \mu \mathrm{Ci} / \mathrm{g}$ of Soil (Dry Weight)

\begin{tabular}{|c|c|c|c|c|c|}
\hline \multirow{2}{*}{$\begin{array}{c}\text { Sample } \\
\text { Location }\end{array}$} & \multirow{2}{*}{$\begin{array}{c}\text { Map } \\
\text { Location } \\
\end{array}$} & \multicolumn{4}{|c|}{ Naturally Occurring Radio } \\
\hline & & $40 \mathrm{~K}$ & ${ }^{224} \mathrm{Ra}$ & $226 \mathrm{Ra}$ & U-total \\
\hline Analytical Limit & & 1.8 & 0.08 & 0.12 & 0.03 \\
\hline Exxon Site & 30 & 13 & 0.59 & $0.3 \varepsilon$ & 0.14 \\
\hline Prosser Earricade & 31 & 14 & 0.56 & 0.46 & 0.21 \\
\hline ALE Field Lab & 32 & 13 & 1.3 & 0.80 & 0.15 \\
\hline Yakima Earricade & 33 & 12 & 0.83 & 0.58 & 0.25 \\
\hline Wahluke $\# 2$ & 34 & 17 & 0.83 & 0.51 & 0.17 \\
\hline Berg Ranch & 35 & 12 & 0.83 & 0.66 & 0.20 \\
\hline Ringold & 36 & 12 & 0.83 & 0.62 & 0.21 \\
\hline 300 Area 331 Bldg. & 37 & 13 & 0.68 & 0.65 & 0.17 \\
\hline Maximum & & 14 & 1.3 & 0.80 & 0.25 \\
\hline Minimum & & 11 & 0.56 & 0.38 & 0.14 \\
\hline
\end{tabular}

Sample

Deviations $(a)$

$13 \pm 1.5 \quad 0.80 \pm 0.43 \quad 0.58 \pm 0.26 \quad 0.210 \pm 0.08$

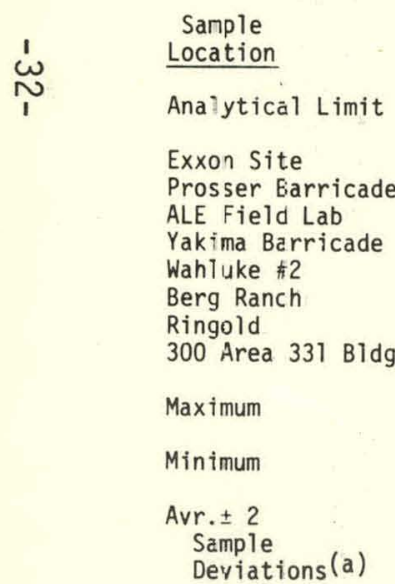

\begin{tabular}{|c|c|c|c|c|c|c|c|c|c|c|c|c|c|}
\hline \multirow{2}{*}{$\begin{array}{c}\text { Map } \\
\text { Location }\end{array}$} & \multicolumn{13}{|c|}{ Artificially Froduced Radionuclides } \\
\hline & $\underline{5+M n}$ & ${ }^{58} \mathrm{CO}_{0}$ & ${ }^{\mathrm{E}} \mathrm{C} \mathrm{Co}$ & $\underline{65} \mathrm{Zn}$ & $90 \mathrm{sr}$ & $95 \mathrm{ZrNb}$ & $106 \mathrm{Ru}-\mathrm{Rh}$ & ${ }^{134} \mathrm{Cs}$ & $\underline{137} \mathrm{Cs}_{\mathrm{s}}$ & ${ }^{144} \mathrm{Ce}$ & ${ }^{154} \mathrm{Eu}$ & $238 \mathrm{Pu}$ & $239-24 \cup \mathrm{pu}$ \\
\hline \multirow{13}{*}{$\begin{array}{l}30 \\
31 \\
32 \\
33 \\
34 \\
35 \\
36 \\
37\end{array}$} & 0.02 & 0.02 & 0.03 & 0.04 & 0.01 & C. .39 & 0.16 & 0.02 & 0.07 & 0.12 & 0.16 & 0.003 & 0.001 \\
\hline & * & * & * & 0.14 & 0.56 & * & 0.29 & * & 0.67 & 0.20 & * & * & 0.02 \\
\hline & * & * & ${ }^{\star}$ & * & 0.18 & * & 0.30 & $0: 05$ & 0.20 & $\star$ & * & * & * \\
\hline & * & * & * & $\star$ & 0.47 & C. .20 & * & 夫 & 1.6 & 0.27 & * & * & 0.01 \\
\hline & * & * & 0.10 & 0.09 & 0.12 & * & 0.18 & * & 0.10 & 0.16 & 0.25 & * & 0.005 \\
\hline & 0.03 & * & * & 0.10 & 0.10 & * & * & * & 0.31 & 0.16 & $\star$ & * & * \\
\hline & 0.03 & * & * & * & 0.18 & * & 0.40 & 0.03 & 0.32 & $\star$ & * & * & * \\
\hline & $\star$ & 0.03 & * & * & 0.07 & * & 0.30 & * & 0.17 & 0.11 & * & * & 0.004 \\
\hline & * & * & * & 0.09 & 0.05 & $C .40$ & * & * & 0.06 & 0.24 & * & * & * \\
\hline & 0.03 & 0.03 & 0.10 & 0.14 & 0.56 & $C .40$ & 0.40 & 0.05 & 1.6 & 0.27 & 0.25 & * & 0.02 \\
\hline & * & * & * & * & * & * & * & * & 0.06 & * & * & * & * \\
\hline & & & & & & & & & & & & & \\
\hline & $<0.01$ & $<0.009$ & $<0.01$ & $<0.06$ & $0.22 \pm 0.38$ & * & $<0.17$ & $<0.01$ & $0.42 \pm 0.99$ & $<0.16$ & $<0.04$ & $<0.0004$ & $<0.007$ \\
\hline
\end{tabular}

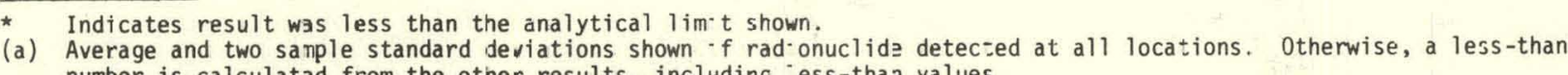
number is calculated from the other results, including "ess-than values. 
TABLE 17. Concentrations of Radionuclides in Perimeter Vegetation Samples - 1975 Units of $10^{-6} \hat{\mu} \mathrm{Ci} / \mathrm{g}$ of Vegetation (Dry Weight)

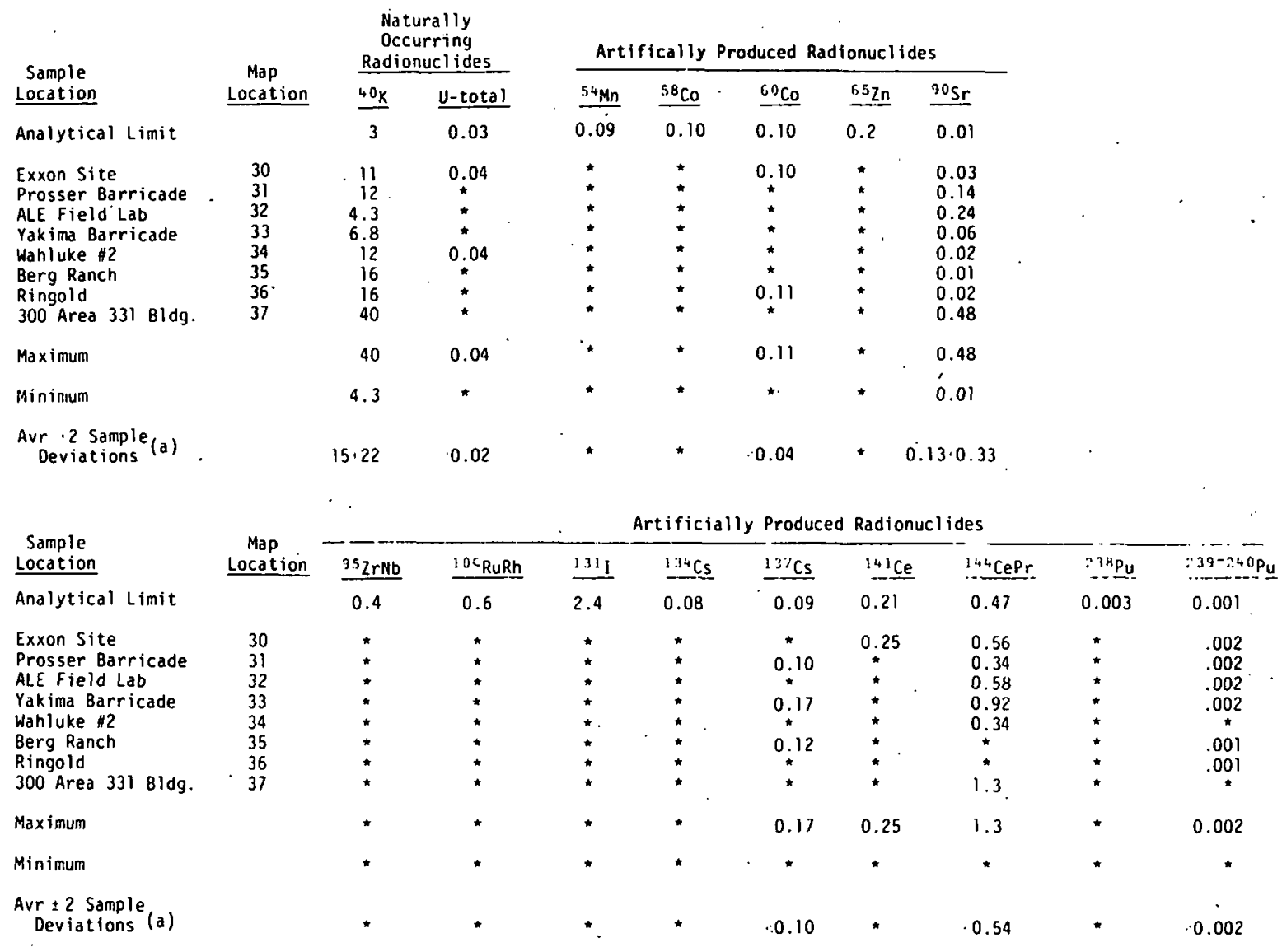

Indicates result was less than the analytical limit shown.

(a) Average and two sample standard deviations shown if radionuclide detected at all locations. Otherwise, a less-than number is calculated from the other results, including less-than values. 
gamma emitting radionuclides using a lithium drifted germanium detector, for plutonium isotopes using alpha spectroscopy, and for $90 \mathrm{Sr}$ and uranium by specific chemical analysis.

Potassium-40, ${ }^{90} \mathrm{Sr},{ }^{137} \mathrm{Cs}, 224 \mathrm{Ra}, 226 \mathrm{Ra}$, and uranium were observed in soil samples from all locations. All of these radionuclides occur naturally

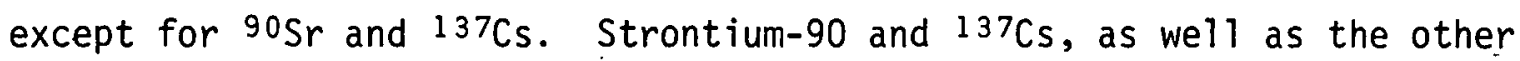
artificially produced radionuclides shown in Tables 16 and 17 , are produced by fission and must be due to efther Hanford operations or to falloul of radioactive debris from the atmosphere from past nuclear device testing. Hanford operations would be expected to contribute to radionuclide concentrations measured at predominately downwind sampling locations (Baxter Substation, Byers Landing, 300 Area south gate, etc.) than to those at. sampling locations lying in an improbable wind direction from Hanford facilities (Prosser Barricade, Wahluke \#2, etc.). No distinct pattern is apparent because of the variability of results measured at all locations. Hence, contributions to radioactivity by Hanford operations were indistinguishable from the variability in concentrations due to fallout.

During the spring of 1975, sediment samples were collected at 21 locations along the Columbia River and islands and analyzed (Figure 8 ). The results of these are presented in Table 18 and 19. The radionuclides observed in the sediment samples at ail locations included $40 \mathrm{~K}, 224 \mathrm{Ra}$, and $226 \mathrm{Ra}$ (natrually occurring) and ${ }^{60} \mathrm{Co}$, and ${ }^{137} \mathrm{Cs}$ (artifically produced). Those radionuclides occurring in most of the samples included ${ }^{144} \mathrm{Ce}, 152 \mathrm{Eu}$, and ${ }^{1.54} \mathrm{Eu}$. An aerial survey of the river by EG\&G of Las Vegas ${ }^{9}$ in 1974 noted elevated levels of ${ }^{60} \mathrm{Co}$ at many of the islands and shoreline locations. This previously noted radioactivity and the radionuclides detected in the sediment samples taken in 1975 are assumed to be due to past Hanford operations. The observed radionuclides remain in the river sediments because of the past operation of once-through-cooling production reactors. The periodic flooding of islands and low-lying areas during high water, 
TABLE 18. Concentrations of Radionuclides in Sediment Sampled at Columbia River Island and Shorel ine Locations - 1975

Units of $\mathrm{pCi} / \mathrm{g}$ (dry weight)

\begin{tabular}{|c|c|c|c|c|c|c|c|c|c|c|c|c|c|c|}
\hline & Hap. & & $\begin{array}{l}\text { urally oc } \\
\text { edionucli }\end{array}$ & $\begin{array}{l}\text { urring } \\
\text { les }\end{array}$ & & & & Arti & cially $p$ & oduced Ra & inucl ic & & & \\
\hline River Mile & Location & $40 \mathrm{~K}$ & $224 \mathrm{Ra}$ & $226 \mathrm{Ra}$ & $54 \mathrm{Mn}$ & ${ }^{60} \mathrm{CO}_{0}$ & $652 n$ & $106 \mathrm{Ru}$ & $.134 \mathrm{Cs}$ & $137 \mathrm{Cs}$ & $744 \mathrm{Ce}$ & $152 \mathrm{Eu}$ & $15^{16} \mathrm{Eu}$ & $155 \mathrm{Ev}$ \\
\hline & Detection Limit $^{(a)}$ & 1.8 & 0.08 & 0.12 & 0.02 & 0.03 & 0.04 & 0.16 & 0.02 & 0.07 & 0.12 & 0.06 & 0.16 & 0.04 \\
\hline & 1 & 11 & 1.3 & 0.4 & $\star$ & 0.2 & * & $\star$ & 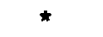 & 0.4 & 0.1 & 0.2 & 0.1 & $\star$ \\
\hline $\begin{array}{l}379.8 \\
377\end{array}$ & 2 & 11 & 1.8 & 0.7 & 0.05 & 0.6 & 0.4 & 0.15 & 0.02 & 0.7 & 0.4 & 0.3 & 0.8 & 0.3 \\
\hline $\begin{array}{l}377.3 \\
376.6\end{array}$ & $\begin{array}{l}3 \\
4\end{array}$ & 11 & $\begin{array}{l}2.9 \\
2.8\end{array}$ & $\begin{array}{l}0.6 \\
0.9\end{array}$ & 0.2 & $\begin{array}{l}2.4 \\
9.6\end{array}$ & 0.2 & $\star$ & 0.7 & $0.8-8-3 x$ & 0.6 & 1.5 & 0.5 & $\star$ \\
\hline 370.6 & 6 & 12 & 1.3 & 0.4 & $\star$ & 0.06 & $\star$ & t & 0.02 & $\begin{array}{l}0.8 \\
0.07\end{array}$ & $\begin{array}{l}0.9 \\
0.2\end{array}$ & 0.4 & $\begin{array}{l}0.2 \\
0.2\end{array}$ & * \\
\hline 368.0 & 7 & 12 & 2.1 & 0.7 & * & 1.1 & $\star$ & * & $\star$ & 1.7 & 0.2 & 1.6 & 0.4 & * \\
\hline $\begin{array}{l}363.1 \\
362.6\end{array}$ & 10 & 14 & 2.28 & 0.5 & * & 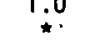 & 0.1 & 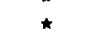 & & 0.0 & 0.3 & 0.7 & 0.1 & * \\
\hline 359.0 & 11 & 14 & 3.2 & 0.7 & 0.04 & 0.7 & 0.1 & $\star$ & 0.05 & 0.4 & $\star$ & 0.3 & * & 0.1 \\
\hline 346.0 & 13 & 14 & 1.5 & 0.6 & 0.2 & 6.2 & 0.1 & 0.2 & 0.02 & 1.8 & $\star$ & 2.2 & 0.8 & $\star$ \\
\hline 344.6 & 14 & 11 & 2.2 & $\begin{array}{l}0.8 \\
0.8\end{array}-1$ & $\begin{array}{l}0.07 \\
0.02\end{array}$ & 2.4 & 0.1 & 0.3. & 0.03 & 0.5 & 0.4 & 0.7 & 0.2 & * \\
\hline $\begin{array}{l}342.7 \\
340.3\end{array}$ & $\begin{array}{l}15 \\
16\end{array}$ & 14 & 1.0 & $\begin{array}{l}0.8 \\
0.4\end{array}$ & 0.02 & $\begin{array}{l}2.1 \\
0.6\end{array}$ & $\pi$ & 0.7 & $\star$ & $\begin{array}{l}0.7 \\
1.0\end{array}$ & * & 0.3 & 0.4 & * \\
\hline 333.3 & 18 & 13 & 1.1 & 0.4 & 0.1 & 2.5 & * & $\star$ & * & 0.5 & 0.1 & $\begin{array}{l}0.6 \\
0.6\end{array}$ & * & * \\
\hline 332.2 & 19 & 13 & 1.6 & 0.8 & 0.06 & 2.1 & * & * & 0.05 & 1.0 & 0.1 & 0.9 & 0.2 & 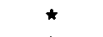 \\
\hline 332.0 & 20 & 12 & 2.8 & 1.1 & 0.04 & 3.2 & * & $\star$ & & 1.6 & 0.4 & 1.9 & 1.2 & * \\
\hline 324.5 & Replicates & & & & & & & & & & & & & \\
\hline & $21-1$ & 11 & 1.9 & 0.6 & & & $\star$ & 0.1 & * & 1.2 & $\star$ & 0.6 & 0.1 & * \\
\hline & $21-2$ & 12 & 1.5 & 0.5 & $\star$ & 0.2 & 0.1 & * & 0.03 & 0.5 & 0.08 & 0.1 & * & * \\
\hline & $\begin{array}{l}21-3 \\
27-4\end{array}$ & 11 & $\begin{array}{l}2.6 \\
1.6\end{array}$ & $\begin{array}{l}.06 \\
0.6\end{array}$ & * & $\begin{array}{l}.0 \\
0.2\end{array}$ & 0.1 & 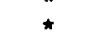 & 0.02 & 0.6 & $\begin{array}{l}0.15 \\
0.14\end{array}$ & 0.8 & 0.2 & * \\
\hline & $27-5$ & 13 & 1.3 & 0.4 & $t$ & $\star$ & 0.1 & & 0.0 & 0.3 & 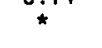 & 0.1 & 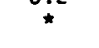 & * \\
\hline & Averages ${ }^{(b)}$ & $12 \pm 3$ & 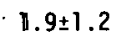 & $0.6 \pm 0.4$ & $<0.05$ & $<1.73$ & $<0.09$ & $<0.12$ & $<0.02$ & $0.8 \pm 1.0$ & $<0.23$ & $<0.67$ & $<0.31$ & $<0.05$ \\
\hline
\end{tabular}

* Less than the analytical detection limit.

(a) The analytical detection limit listed is the average of individual analytical detection limit for each analyses.

(b) Average and two sample standard deviations shown if radionuclide detected at all locations. 0therwise, a less-than number is calculated from the other results, including less-than values. 
TABLE 19. Depth Profile of Radicnuclide Concentrations in Sediment Sampled at Selected Columbia Fiver Island and Shoreline Locatioris - 1975

Units of $\mathrm{pCi} / \mathrm{g}$ (dry weight)

\begin{tabular}{|c|c|c|c|c|c|c|c|c|c|c|c|c|c|c|c|c|c|c|}
\hline & & & $\begin{array}{r}\text { Natu } \\
\text { Ra }\end{array}$ & $\begin{array}{l}0 \mathrm{cc} \\
\mathrm{Acljc}\end{array}$ & & & & & & & Artificia & $11 y$ Prod & luced Rad & dioncclid & & & & \\
\hline & $\begin{array}{l}\text { River } \\
\text { Mile } \\
\end{array}$ & $\begin{array}{c}\text { Map } \\
\text { Location }\end{array}$ & $40 \mathrm{~K}$ & $=24 R a$ & $2 \cong 6 R a$ & $5+M n$ & ${ }^{60} \mathrm{CCO}$ & $65 \mathrm{Zn}$ & ${ }^{06} R u$ & ${ }^{134} \mathrm{Cs}$ & $137 \mathrm{Cs}$ & ${ }^{144} \mathrm{Ce}$ & $152 \mathrm{Eu}$ & 15LEU & $155 \mathrm{Eu}$ & $90 \mathrm{sr}$ & $238 \mathrm{Pu}$ & $239-240 \mathrm{Pu}$ \\
\hline & $\begin{array}{r}\text { Analyt } \\
\mathrm{L}\end{array}$ & (a) tection & 1.8 & 0.08 & 3.12 & 0.32 & $0 . C 3$ & 0.04 & 0.16 & 0.02 & 0.07 & 0.12 & 0.06 & 0.16 & 0.04 & 0.01 & 0.003 & 0.001 \\
\hline & 371.4 & $\begin{array}{c}5-0-1 " \\
1-2^{\prime \prime} \\
2-4^{\prime \prime} \\
4-6^{\prime \prime} \\
6-8^{\prime \prime}\end{array}$ & $\begin{array}{l}14 \\
14 \\
12 \\
12 \\
12\end{array}$ & $\begin{array}{l}7.5 \\
2.0 \\
1.4 \\
2.5 \\
5.7\end{array}$ & $\begin{array}{l}1.1 \\
0.8 \\
0.5 \\
1.0 \\
1.1\end{array}$ & $\begin{array}{c}\star \\
\star \\
\star \\
\star \\
\star \\
\star\end{array}$ & $\begin{array}{l}1.0 . \\
0.4 \\
0.6 \\
0.2 \\
0.3\end{array}$ & $\begin{array}{c}0.06 \\
\star \\
\star \\
\star \\
\star\end{array}$ & $\begin{array}{l}\star \\
\star \\
0.2 \\
0.2\end{array}$ & $\begin{array}{l}0.06 \\
0.5 \\
\star \\
0.06 \\
\star\end{array}$ & $\begin{array}{l}1.6 \\
0.9 \\
1.9 \\
3.3 \\
0.6\end{array}$ & $\begin{array}{l}0.5 \\
* \\
0.1 \\
0.1 \\
0.2\end{array}$ & $\begin{array}{l}0.7 \\
0.9 \\
1.2 \\
1.0 \\
0.6\end{array}$ & $\begin{array}{l}0.2 \\
0.2 \\
* \\
\star \\
\star\end{array}$ & $\begin{array}{l}0.05 \\
\star \\
\star \\
0.07\end{array}$ & 0.05 & * & 0.004 \\
\hline & 367.3 & $\begin{array}{r}8-0-1^{\prime \prime} \\
1-2^{\prime \prime} \\
2-4 " \\
4-6^{\prime \prime} \\
6-8 "\end{array}$ & $\begin{array}{l}12 \\
12 \\
13 \\
13 \\
14\end{array}$ & $\begin{array}{l}2.5 \\
1.9 \\
1.3 \\
2.2 \\
1.9\end{array}$ & $\begin{array}{l}0.9 \\
0.7 \\
0.6 \\
0.9 \\
0.6\end{array}$ & $\begin{array}{l}0.04 \\
0.05 \\
+ \\
0.02\end{array}$ & $\begin{array}{l}3.5 \\
7.3 \\
1.5 \\
0.5 \\
0.08\end{array}$ & $\begin{array}{l}0.05 \\
0.05 \\
\star \\
0.05 \\
0.08\end{array}$ & $\begin{array}{l}0.3 \\
0.2 \\
\star \\
* \\
*\end{array}$ & $\begin{array}{l}0.06 \\
\vdots \\
0.08 \\
\star \\
\star\end{array}$ & $\begin{array}{l}1.7 \\
1.5 \\
1.2 \\
0.6 \\
0.05\end{array}$ & $\begin{array}{l}0_{\star}^{\star} \\
\star \\
0.2\end{array}$ & $\begin{array}{l}2.8 \\
2.8 \\
2.7 \\
1.1 \\
0.07\end{array}$ & $\begin{array}{l}1.0 \\
0.6 \\
0.7 \\
0.5 \\
0.3\end{array}$ & $\stackrel{\star}{\star}^{\star}$ & 0.03 & * & 0.013 \\
\hline & 349.8 & 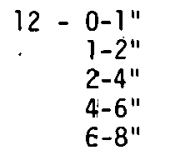 & $\begin{array}{l}12 \\
12 \\
12 \\
13 \\
13\end{array}$ & $\begin{array}{l}2.0 \\
1.5 \\
1.6 \\
2.0 \\
1.1\end{array}$ & $\begin{array}{l}0.7 \\
0.9 \\
0.6 \\
0.5 \\
0.5\end{array}$ & $\begin{array}{l}\star \\
. \\
\star \\
\star \\
\star\end{array}$ & $\begin{array}{l}1.7 \\
1.5 \\
1.1 \\
0.2 \\
0.03\end{array}$ & $\begin{array}{l}* \\
* \\
* \\
0.04\end{array}$ & $\begin{array}{l}\star \\
0.2 \\
\star \\
\star \\
\star\end{array}$ & $\begin{array}{l}0.07 \\
0.06 \\
0.02 \\
0.02 \\
\star\end{array}$ & $\begin{array}{l}1.8 \\
0.5 \\
1.1 \\
0.5 \\
0.3\end{array}$ & $\begin{array}{c}0.1 \\
1.0 \\
0.1 \\
0.2 \\
\star\end{array}$ & $\begin{array}{l}3.8 \\
2.6 \\
0.5 \\
0.1 \\
\star\end{array}$ & $\begin{array}{l}3.3 \\
5.0 \\
3.1 \\
\star \\
0.1\end{array}$ & $\begin{array}{l}\star \\
1.6 \\
0.06 \\
\star \\
\star\end{array}$ & $\begin{array}{c}0.3 \\
.\end{array}$ & $\stackrel{\star}{*}$ & $<0.1$ \\
\hline & 340.0 & $\begin{array}{r}17-0-1 " \\
1-2^{\prime \prime} \\
2-4 " \\
4-6 " \\
6-8 "\end{array}$ & $\begin{array}{r}16 \\
14 \\
12 \\
14 \\
14 \\
12\end{array}$ & $\begin{array}{l}1.1 \\
2.0 \\
2.8 \\
1.0 \\
1.3\end{array}$ & $\begin{array}{l}0.5 \\
1.0 \\
1.1 \\
0.6 \\
0.6\end{array}$ & $\begin{array}{l}0.04 \\
* \\
* \\
\star \\
*\end{array}$ & $\begin{array}{l}1.4 \\
2.3 \\
2.8 \\
0.8 \\
0.2\end{array}$ & $\begin{array}{l}\star \\
\star \\
0.07 \\
0.05 \\
0.05\end{array}$ & $\begin{array}{l}\star \\
\star \\
\star \\
\star \\
\star\end{array}$ & $\begin{array}{l}\star \\
\star \\
\star \\
0.02 \\
0.04\end{array}$ & $\begin{array}{l}0.6 \\
1.5 \\
2.6 \\
1.2 \\
0.9\end{array}$ & $\begin{array}{l}0.2 \\
\star \\
0.2 \\
0.2 \\
0.2\end{array}$ & $\begin{array}{l}0.6 \\
1.3 \\
3.1 \\
1.1 \\
0.3\end{array}$ & $\begin{array}{l}\star \\
1.0 \\
0.7 \\
0.4 \\
\star\end{array}$ & $\begin{array}{l}\star \\
\star \\
\star \\
\star \\
\text { * }\end{array}$ & 0.1 & $\star$ & $<0.1$ \\
\hline & Averag & $\begin{array}{l}13-1 " \\
1-2 " . \\
2-4^{\prime \prime} \\
4-6^{\prime \prime} \\
6-8^{\prime \prime}\end{array}$ & $\begin{array}{l}13.5 \pm 3.8 \\
13.0 \pm 2.5 \\
12.3 \pm 1.6 \\
13.0 \pm 1.6 \\
12.8 \pm 1.4\end{array}$ & $\begin{array}{l}3.3 \pm 5.6 \\
1.5 \pm 0.5 \\
1.5 \pm 1.2 \\
1.5 \pm 1.3 \\
4.0 \pm 4.3\end{array}$ & $\begin{array}{l}0.8 \pm 0.5 \\
0.9 \pm 0.3 \\
0.7 \pm 0.5 \\
0.8 \pm 0.5 \\
0.7 \pm 0.5\end{array}$ & $\begin{array}{c}<3.03 \\
<0.05 \\
\star \\
\infty \\
\star \\
\star\end{array}$ & $\begin{array}{l}1.9=2 \\
2.9=6.1 \\
1.5 \pm 1.9 \\
0.5 \pm 0.6 \\
0.1 \pm 0.1\end{array}$ & $\begin{array}{l}<0.04 \\
<0.04 \\
<0.04 \\
<0.04 \\
<0.05\end{array}$ & $\begin{array}{c}<0.2 \\
<0.2 \\
<0.1 \\
<0.7 \\
\star\end{array}$ & $\begin{array}{l}<0.05 \\
<0.15 \\
<0.03 \\
<0.03 \\
<0.02\end{array}$ & $\begin{array}{l}1.4 \pm 1.1 \\
1.1 \pm 1.0 \\
1.7 \pm 1.4 \\
1.4 \pm 2.6 \\
0.5 \pm 0.7\end{array}$ & $\begin{array}{l}<0.2 \\
<0.3 \\
<0.1 \\
<0.1 \\
0.2 \pm 0.0\end{array}$ & $\begin{array}{l}1.5 \pm 2.1 \\
.1 .9 \pm 1.9 \\
1.9 \pm 2.5 \\
0.8 \pm 1.0 \\
50.3\end{array}$ & $\begin{array}{l}=0.4 \\
2.0<5.4 \\
=0.4 \\
<0.3 \\
<0.1\end{array}$ & $\begin{array}{c}<0.05 \\
<0.43 \\
\star \\
<0.06 \\
\vdots \\
\vdots\end{array}$ & $0.12 \quad 0.25$ & 5 * & $<0.05$ \\
\hline
\end{tabular}

* Less then the enalytial detection limit

(a) The ana ytical detection limit listed is the average of individuai analytical detection limit for each ana ${ }^{\text {iyses. }}$

(b) Average and two sample standard deviations shown $i=$ racionuclide detected at all locations. Otherwise, a less-than number is calculated from the other results, including less-thar values. 
resulting in the deposition of these sediments, is the probable reason for the observed concentrations. This phenomenum is explored in detail in a separate publication. 10

Results of depth profile samples indicated a slight increase in the levels of radioactivity in the one to two-inch layer for ${ }^{60} \mathrm{Co}, 154 \mathrm{Eu}$, and ${ }^{155} \mathrm{Eu}$, although this may be due to the natural variability of environmental sampling as demonstrated by the replicate samples taken at location 21 .

\section{EXTERNAL RADIATION MEASUREMENT}

External radiation levels in the Hanford environs were measured during 1975 by several methods. Thermoluminescent dosimeters (TLDs) were deployed at 12 perimeter and 5 distant locations to measure the ambient radiation dose received from natural and fallout radioactivity as well as to detect any contribution from Hanford operations. TLDs.were submerged in the Columbia River at four locations. State highways through the site, control plots, and Columbia River shoreline were routinely surveyed with portable instruments to detect any trend in ambient radiation levels.

\section{Ambient Radiation Dose}

TLDs were used to measure the external background dose at several perimeter and distant communities. Table 20 shows the results of these measurements. The dosimeter consisted of 3 chips of $\mathrm{CaF}_{2}$ :Dy (Harshaw TLD-200) encased in an opaque plastic capsule lined with 0.010 inch of tantalum and 0.002 inch of lead to flatten the lower energy response.11 The dosimeters were mounted approximately one meter above ground level and changed either biweekly or monthly.

The external dose measured at any location is affected by several parameters, including the height of the dosimeter above ground, the elevation, and the amount of natural and fallout radioactivity in the underlying soil. The variability in measured dose from the diffcrent locations was expected primarlly because of the spatial dependence of natural radioactivity in soil. Contributions from Hanford operations were indiscernible from the variability in background dose measured at the different communities. 
IABLE 20. Ambient Radiation Dose - 1975(a)

\begin{tabular}{|c|c|c|c|c|}
\hline \multirow{2}{*}{\multicolumn{2}{|c|}{ Location $\quad \begin{array}{r}\text { No. of }(b) \\
\text { Measurements }\end{array}$}} & \multicolumn{3}{|c|}{ Dose (mrem/yr) ${ }^{(c)}$} \\
\hline & & Maximum & Minimum & Average \\
\hline \multicolumn{5}{|c|}{ Perimeter Community Dose } \\
\hline $\begin{array}{l}\text { Pasco } \\
\text { Richland } \\
\text { Vernita } \\
\text { Benton City } \\
\text { Othello } \\
\text { Connell } \\
\text { Berg Ranch. } \\
\text { Wahluke Wm. } \\
\text { Cooke Bros. } \\
\text { Ringold } \\
\text { Baxter Sub. } \\
\text { Byers Landing }\end{array}$ & $\begin{array}{l}12 \\
26 \\
25 \\
13 \\
13 \\
13 \\
13 \\
11 \\
13 \\
10 \\
13 \\
13\end{array}$ & $\begin{array}{r}80 \\
77 \\
102 \\
69 \\
69 \\
69 \\
84 \\
77 \\
73 \\
91 \\
73 \\
91\end{array}$ & $\begin{array}{l}66 \\
62 \\
77 \\
51 \\
51 \\
55 \\
73 \\
69 \\
62 \\
77 \\
58 \\
73\end{array}$ & $\begin{array}{l}70 \pm 8 \\
71 \pm 7 \\
88 \pm 12 \\
60 \pm 9 \\
60 \pm 10 \\
65 \pm 8 \\
78 \pm 8 \\
73 \pm 6 \\
68 \pm 7 \\
85 \pm 9 \\
67 \pm 9 \\
78 \pm 10\end{array}$ \\
\hline \multicolumn{3}{|c|}{ Average \pm 2 sample standard deviations } & . & $\overline{72 \pm 18}$ \\
\hline \multicolumn{5}{|c|}{ Distant Community Dose } \\
\hline $\begin{array}{l}\text { Walla Walla } \\
\text { Sunnyside } \\
\text { McNary } \\
\text { Moses Lake } \\
\text { Washtucna }\end{array}$ & $\begin{array}{l}13 \\
13 \\
12 \\
13 \\
13\end{array}$ & $\begin{array}{l}77 \\
69 \\
84 \\
73 \\
73\end{array}$ & $\begin{array}{l}66 \\
58 \\
66 \\
58 \\
58\end{array}$ & $\begin{array}{l}13 \pm 7 \\
65 \pm 8 \\
73 \pm 9 \\
67+7 \\
68+8\end{array}$ \\
\hline Average \pm 2 san & le standard & & & $\overline{69 \pm 7}$ \\
\hline
\end{tabular}

(a) Total background dose from external irradiation would include an additional dose from the neutron component of cosmic radiation. This is estimated to be equivalent to $4 \mathrm{mrem} / \mathrm{year}$ at the elevation of the Hanford region from EPA publication ORP/SID 72-1.

(b) Dosimeters are generdlly deployed on a lwu-week or four-wrek interval. This practice results in approximately 26 or 13 separate measurements at each location. There is some variability because of scheduling and year-to-year overlap.

(c) Monthly or biweekly measurements converted to equivalent annual dose. Average \pm 2 sample standard deviations calculated for each location. 
The external background dose received by the population in the Hanford environs can be estimated from the data in Table 20. The average measured dose and $95 \%$ confidence interval at perimeter locations was about $72 \pm 18$ $\mathrm{mrem} /$ year ( $1 \mathrm{mrem}$ equals $1 \mathrm{mrad}$ in this case). To this number, an additional $6 \mathrm{mrem} /$ year must be added to account for the neutron component of cosmic radiation. 12 Thus an estimate of $78 \pm 18 \mathrm{mrem} / \mathrm{yr}$ from external radiation would be realistic. An estimate of the total (external plus internal) background dose must include the approximate $25 \mathrm{mrem} /$ year received from radioactivity, primarily ${ }^{40} \mathrm{~K}$, in our bodies. 4 Therefore, the average total background dose received in the Hanford environs is approximately $103 \pm 18$ $\mathrm{mrem} /$ year.

\section{Columbia River Immersion Dose}

TLDs were submerged in the Columbia River at four locations: Coyote Rapids (above 100-K Area), below 100-N, Hanford powerline, and the Richland pumphouse. The TLDs were collected monthly and the results (shown in Table 21) are similar to 1974.13. The information was used to evaluate the dose rate received while swimming in the river. At Richland, an immersed swimmer would receive approximately $0.004 \mathrm{mrad} / \mathrm{hr}$, compared to approximately $0.008 \mathrm{mrad} / \mathrm{hr}$ received on land (Table 19).

\section{TABLE 21. Columbia River Immersion Dose Rate - 1975}

\begin{tabular}{lcccc}
\multicolumn{1}{c}{$\begin{array}{c}\text { Location } \\
\text { Coyote Rapids }\end{array}$} & $\begin{array}{c}\text { Measurements } \\
\text { Below 100-N }\end{array}$ & $\underline{\text { Maximum }}$ & $\underline{\text { Minimum }}$ & $\begin{array}{c}\text { Radiation Dose (mrad/hr) } \\
\text { Annerage }\end{array}$ \\
Hanford Powerline & 12 & 0.006 & 0.004 & $0.005 \pm 0.001$ \\
Richland Pumphouse & 10 & 0.010 & 0.004 & $0.007 \pm 0.003$ \\
& 9 & 0.006 & 0.003 & $0.004+0.002$ \\
& 13 & 0.005 & 0.003 & $0.004 \pm 0.001$
\end{tabular}

(a) Monthly measurements in mrad were converted to equivalent hourly dose.

(b) Average \pm 2 sample standard deviations calculated for each location. 


\section{Portable Instrument Surveys}

Roads and land surfaces in the vicinity of Hanford were periodically surveyed to detect possible radionuclide deposition resulting from Hanford operations and related activities. Public Highways 24 and 240 , which traverse the Hanford Reservation, were surveyed quarterly with a bioplastic scintillation detector ${ }^{14}$ attached to the bumper of a truck and positioned about 0.6 meters (2 feet) above the edge of the road surface (described in BNWL-62). No radioactivity other than background was detected during 1975 .

Fleven small areas, called control plots, were located around the Hanford boundaries. These plots, measuring $3 \mathrm{~m} \times 3 \mathrm{~m}(10 \mathrm{ft} \times 10 \mathrm{ft})$ were surveyed monthly or semimonthly with a Geiger-Muller (GM) survey meter for deposited radioactive material. No surface radioactivity of Hanford origin was detected on these control plots during 1975.

The shoreline of the Columbia River was surveyed monthly with a low-level GM counter (Nuclear Enterprises Model 2601) at selected locations to detect any change in ambient radiation levels from previous measurements. The data obtained during 1975 for three of these locations, Vernita, Richland and Sacajawea, are summarized ill Table $\hat{2} 2$. No statistical difforence is apparent between the results for the three locations given the wide variability in ohserved values.

\section{TABLE 22. Columbia River Shoreline Exposure Rate - 1975}

\begin{tabular}{ccccc} 
Shoreline Location & $\begin{array}{c}\text { No. of } \\
\text { Measurements }\end{array}$ & Maximum & Exposure Rate $(\mathrm{mR} / \mathrm{hr})$ \\
\hline Vernita & 6 & 0.015 & 0.006 & $0.009 \pm 0.007$ \\
Richland & 12 & 0.016 & 0.008 & $0.012 \pm 0.005$ \\
Sacajawea & 21 & 0.020 & 0.009 & $0.013 \pm 0.005$
\end{tabular}

(a) Average \pm 2 sample standard deviations for each location. 
Potential environmental exposure pathways from Hanford operations to the population are shown pictorially in Figure 9. Many of these same pathways are responsible for transporting naturally occurring and fallout radioactivity from the environment to man. The evaluation of monitoring data from several environmental media discussed in the previous sections attempted to determine the contribution to ambient radiation levels due to Hanford operations from the contributions due to fallout and natural radioactivity. The contribution from Hanford operations during 1975 to the radiation levels measured in all environmental media (atmosphere, water, foodstuffs, wildlife, soil, and vegetation) were indistinguishable from pre-existing radiation levels. Some of the radioactivity that was measured in occasional samples of wildiife, suspended sediment in river water, soil samples from Columbia River islands, and oysters from Willapa Bay was due to past once-through cooling production reactor operation. The last of these reactors, $K E$, was deactivated during January 1971. The radioactivity in the river sediments and biota due to this cause is gradually becoming undetectable through dilution and radioactive decay.

Table 23 lists the radionuclide composition of effluent reported by all Hanford contractors during 1975. Because of the difficulty in measuring the contribution of these radionuclides to the existing radiation levels due to fallout and natural radioactivity, the radiological impact from Hanford operations during 1975 was estimated from theoretical models relating releases of radioactivity from Hanford operations with subsequent radiation dose to the population. The models 15,16 have been used previously to determine the radiological impact from Hanford facilities (Waste Management Operations - Hanford Reservation - ERDA-1538). 17 There will be small differences in calculated doses from year to year depending on the quantity of effluent, annual meteorology, river flow rate, and calculation methodology. The methods employed are expected to provide a best estimate of the calculated doses due to Hanford operations during 1975. The radiological impact from radioactivity measured in wildlife, island soil samples, river sediments, and oysters from past Hanford operations are addressed separately. 


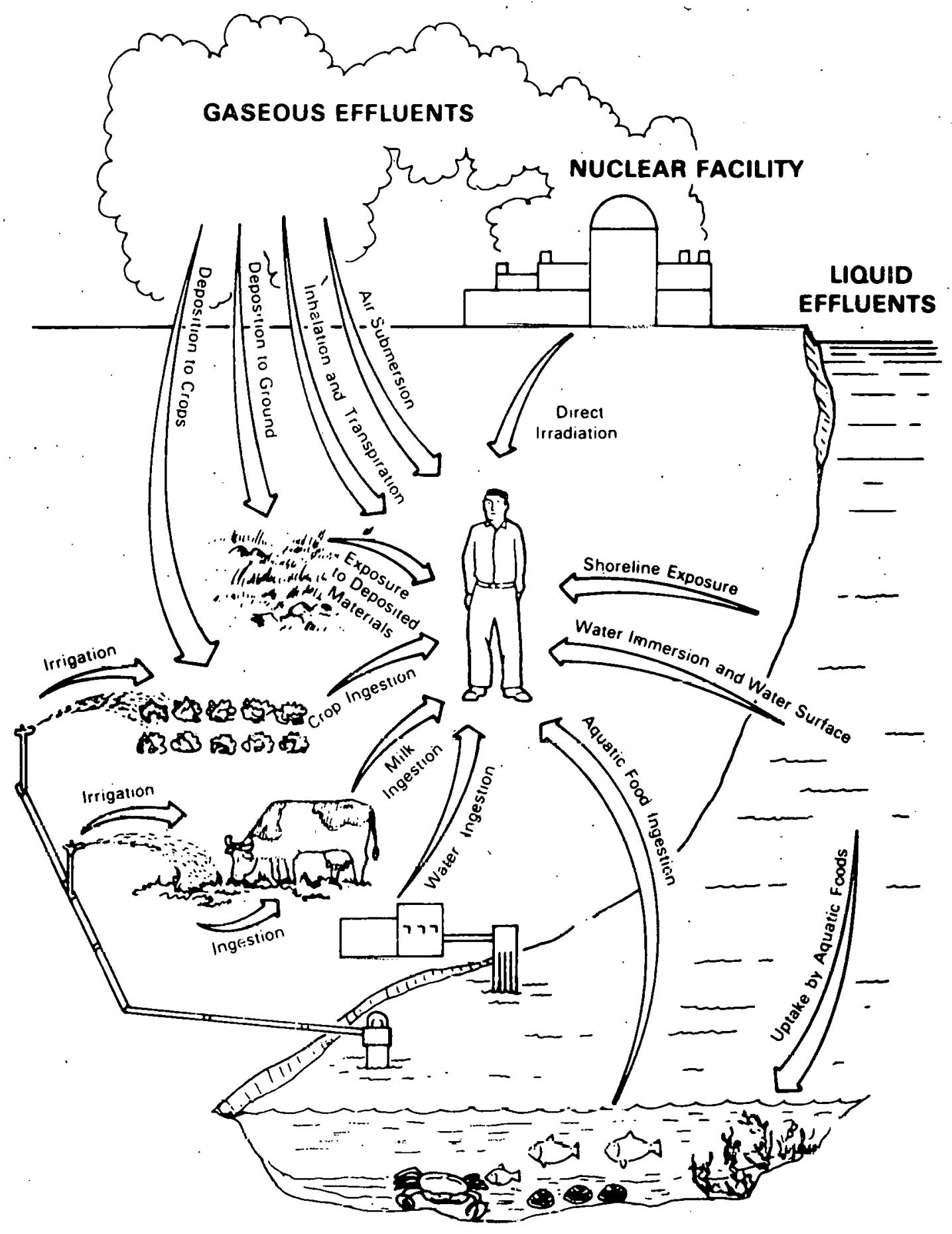

FIGURE 9. Exposure Pathways to Man 15 
TABLE 23. Radionuclide Composition

of 'Effluent-1975(a)

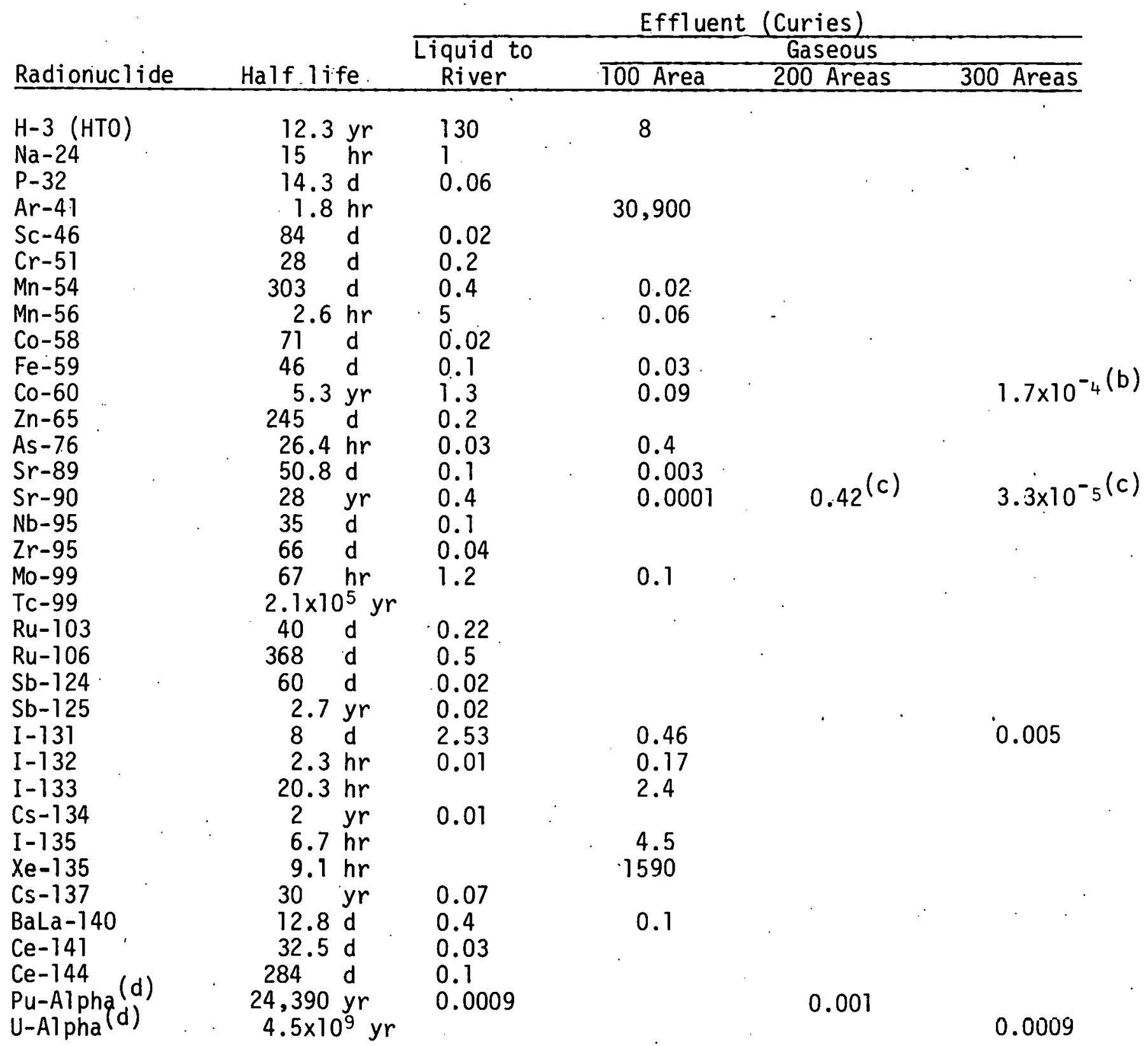

(a) Table includes all reported releases.

(h) Actually reported as mixed activation products. Cobalt-60 assumed for simplification and was used in dose calculations.

(c) Actualiy reported as mixed fission products. Strontium-90 assumed for simplification and was used in dose calculations.

(d) Gross alpha counts for different facilities interpreted as either reflecting Pu-239 or uranium activity depending on the nature of the operations inside the facilities. 


\section{RADIOLOGICAL IMPACT FROM 1975 EFFLUUENT}

Three separate parameters are suggested by ERDA Manual Chapter $0513^{18}$ to evaluate the radiological impact of Hanford operations on the surrounding region. These are:

- Maximum "fence-post" exposure rate at any point on the site boundary.

- Maxilium dose to an individual member of the public.

- Total body dose (man-rem) to the entire population within an 80kilometer (50-mile) radius of the site.

Maximum "Fence-Post" Exposure Rate

The maximum "fence-post" exposure rate during 1975 was calculated to be $6 \times 10^{-6} \mathrm{mR} / \mathrm{hr}$ along the northwest boundary of the Hanford Reservation. Although no one lives in this particular area, the dose potentially received by an individual continuously present on the boundary was estimated to be $0.06 \mathrm{mrem}$. The majority of the dose received would be from ${ }^{41} \mathrm{Ar}$ (halflife 1.8 hours) and $135 \mathrm{Xe}$ (half-1 ife 9.2 hours) released at $N$ Reactor. Maximum Individual Dose

The maximum dose to an individual member of the public during 1975 and the 50-year dose commitment from 1975 effluent were calculated for all of the radionuclides 1 isted in Table 23 .

All significant environmental exposure pathways were evaluated including submersion in the plume, drinking water, foodstuffs irrigated with Columbia River water, atmospheric iodine-pasture-cow-milk pathway, etc. The methods employed are expected to provide a best estimate of the doses due to the different exposure pathways.

Past studies, combined with results of the environmental surveillance program, have facilitated the construction of a hypothetical person whose dietary and recreational hablts maximize the dose he might receive from Hanford operations. Such a hypothetical person is called the maximum individual. The habits and diet of the maximum individual include the maximum reported for each exposure mode in spite of the fact that the maximum 
values are not, in actuality, attributable to the same person. The maximum individual is a person assumed to have the following characteristics:

- Resides continuously directly across the river from the Hanford 300 Area.

- Obtains drinking water from the Columbia River.

- Drinks 275 liters of milk during a nine-month period from a cow eating pasture grass near his residence.

- Eats $710 \mathrm{~kg}$ of produce grown near his residence and irrigated with Columbia River water.

- Eats $40 \mathrm{~kg}$ of fish per year caught from the Columbia River.

- Spends as much as 500 hours per year on the shoreline of the Columbia River, 100 hours per year swimming in the river, and 100 hours per year boating.

The estimated total body dose received during 1975 for such an individual from effluent released during 1975 is $7 \times 10-3$ mrem as shown in Table 24 . The dose received was primarily the result of radionuclides ingested with fish from the Columbia River $\left(2.4 \times 10^{-3}\right)$, foodstuffs irrigated with Columbia River water $\left(1.7 \times 10^{-4}\right.$ mrem), and external radiation from ${ }^{41} \mathrm{Ar}$ and ${ }^{135} \mathrm{Xe}$ releases from $\mathrm{N}$ Reactor $\left(2.6 \times 10^{-3} \mathrm{mrem}\right)$.

The dose potentially received by the thyroid of an infant (one year old) was estimated to be 0.9 mrem from effluent released during 1975, as shown in Table 24. The dose was primarily due to ${ }^{131} \mathrm{I}$ in milk and drinking water. The iodine in milk results from irrigation of the pasture with Columbia River water and deposition on the pasture grass of airborne iodine. Essentially all of the dose would be received during 1975 since ${ }^{131}$ I has an eight-day halflife.

The 50-year total body dose commitment to the maximum individual from 1975 effluents is 0.02 mrem as shown in Table 25. The additional 0.01 mrem received after 1975 is due primarily to the consumption during 1975 of ${ }^{90} \mathrm{Sr}$ in drinking water, fish, and irrigated foods. The bone dose received during 1975 was estimated to be $9 \times 10^{-3}$ mrem due primarily to fish consumption. 
TABLE 24. Estimated Dose to the Maximum Individual During 1975 from Effluents Released from Hanford Facilities During 1975

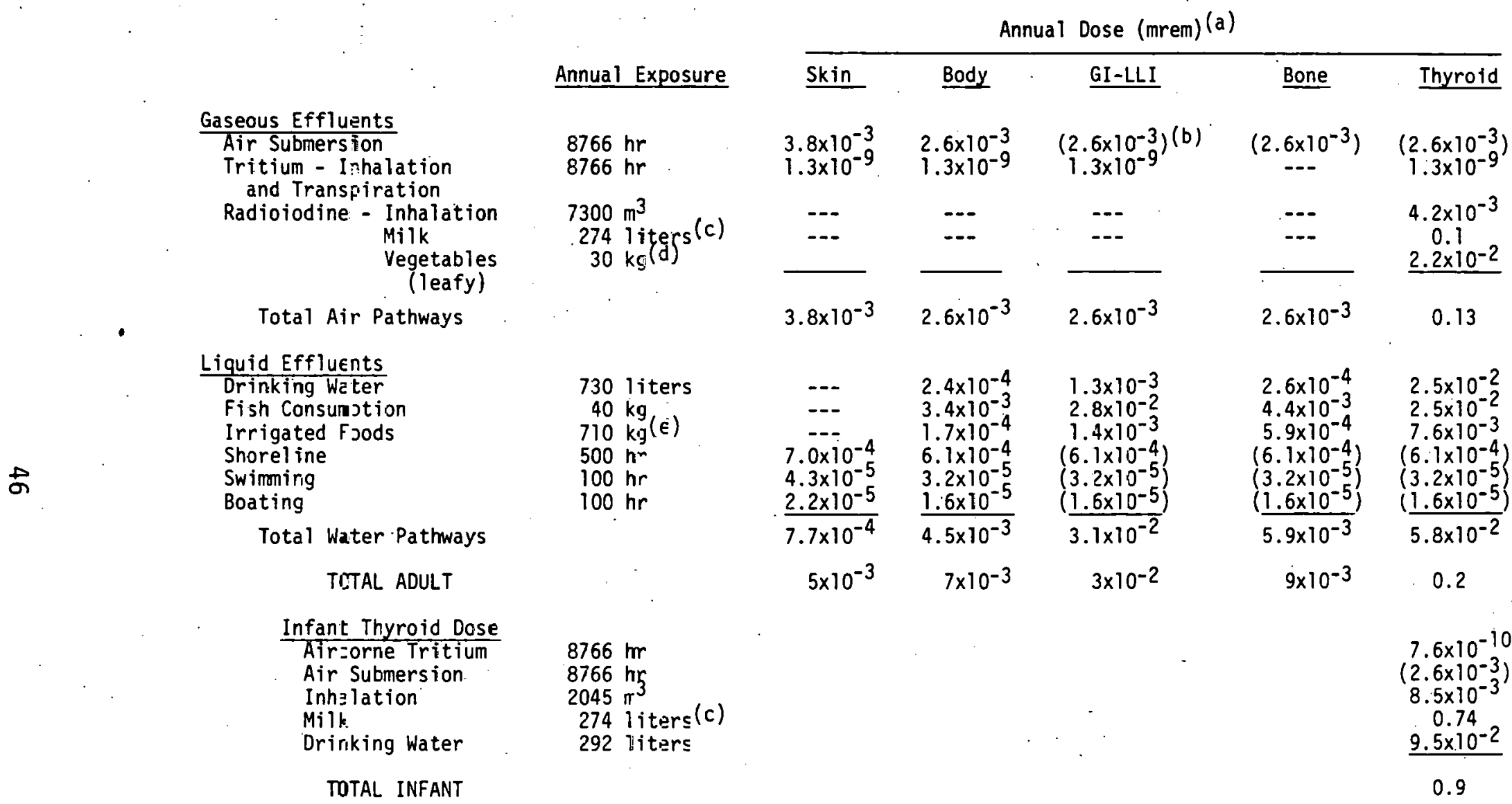

(a) Dose received during: 1975 due to effluent during 1975.

(b) Internal dose from external exposure ndicated by parenthes is ( ).

(c) One liter per day for a 9-month grazing season.

(d) $200 \mathrm{~g} / \mathrm{c}$ for a 5 -month growing season.

(e) Only the potentially irrigated produce is included. 
TABLE 25. Estimated 50-Year Dose Commitment to the Maximum Individua from Effluents Released from Hanford Facilities During 1975

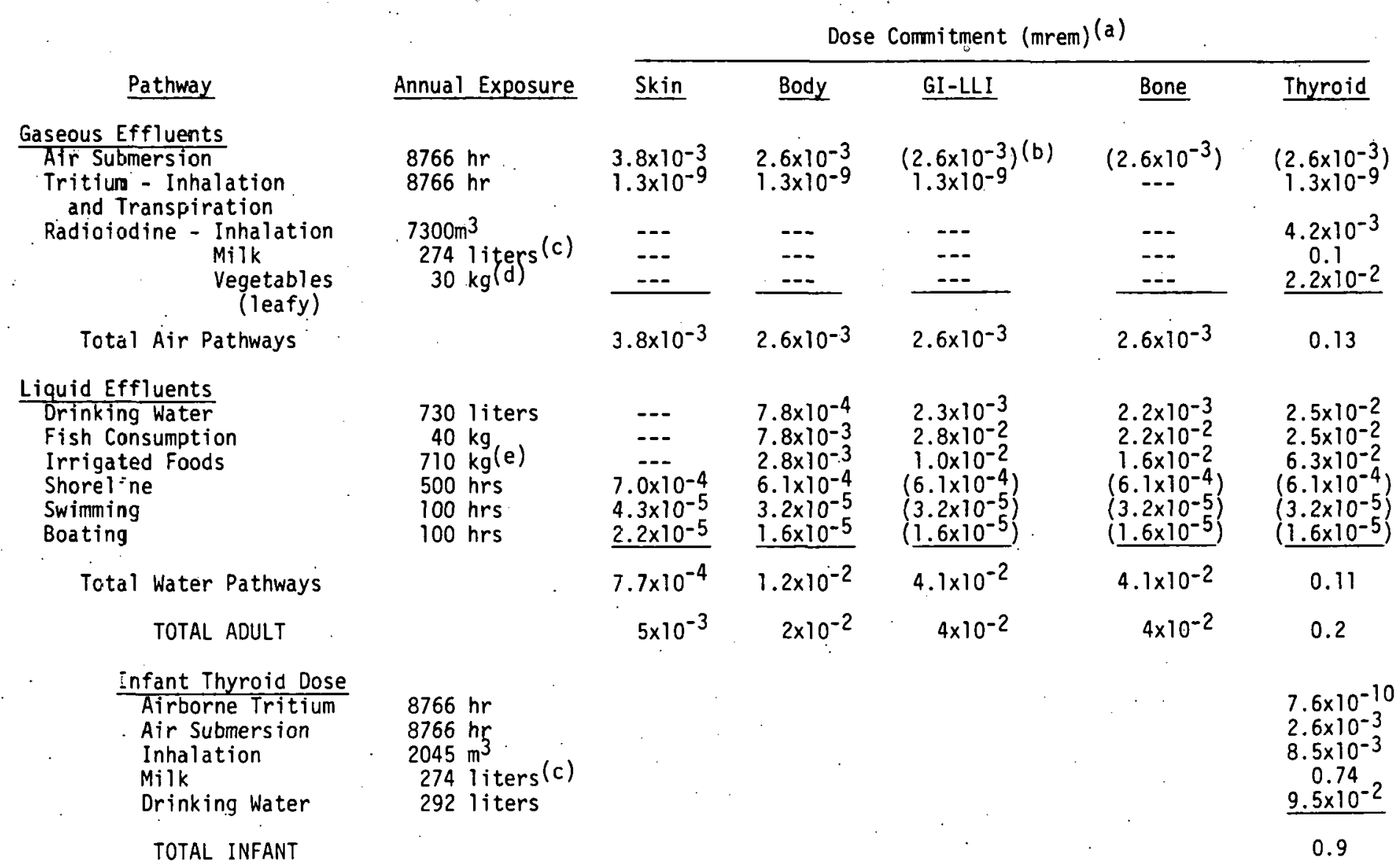

a) Dose comritment for 50 years (1975-2024, inclusive) due to effluents released during 1975.

b) Internal dose from external exposure indicated by parenthesis ().

(c) One liter per day for a 9-month grazing season.

(d) $200 \mathrm{~g} / \mathrm{d}$ for a 5 -month growing season.

(e) Only the potentially irrigated produce is included. 
The 50-year dose commitment to the bone was estimated to be $0.04 \mathrm{mrem}$, as shown in Table 25. The dose received after 1975 is due primarily to ${ }^{90} \mathrm{Sr}$.

For comparison, the maximum individual would also receive each year approximately 72 mrem from background external radiation (page 39), 11 mrem from naturally occurring ${ }^{40} \mathrm{~K}$ in milk (1000 $\mathrm{pCi} / 1$ from Table 12 and 274 liters of milk), 7 mrem from $40 \mathrm{~K}$ in fish ( $4 \mathrm{pCi} / \mathrm{gr}$ from Table 15 and 40 kilograms of fish), approximately 4 mrem from fallout radionuclides ${ }^{4}$, and additional exposure from other natural sources not calculated. Therefore, the maximum individual would have received an additional dose which is $0.02 \%$ of the background dose of 103 mrem/year in the Hanford environs during 1975 due to Hanford operations.

\section{0-Kilometer Radius Population Dose}

The total body population dose received during 1975 by the population within an 80-kilometer (50-mile) radius of the Hanford Reservation and the 50-year dose commitment from effluent released during 1975 were estimated for 111 of the radionuclides listed in Table 23 . Table 26 lists the population dose received during 1975 by the total body, bone, GI-LLI (Gastro-Intestinal tract - Lower Large Intestine), lung, and thyroid. The estimated total body population dose received by the approximate 250,000 people living within the 80-kilometer radius during 1975 was 0.9 man-rem or an average annual dose per capita of $4 \times 10^{-3}$ mrem. This dose is primarily due to external irradiation from ${ }^{41} \mathrm{Ar}$. The dose received by the bone, GI-LLI, and lung is due primarily to external irradiation. The dose to the thyroid is primarily due to isotopes of iodine released to the atmosphere and Columbia River. The population thyroid dose was estimated to be 2.8 man-thyroid-rem during 1975.

Table 27 lists the 50-year dose commitment (1975 to 2024, inclusive potentially received by the 250,000 people from effluents released during 1975 . The total-body population dose commitment was estimated to be 1.5 man-rem, the 0.6 man-rem received by the population after 1975 is primarily from ${ }^{90} \mathrm{Sr}$; with a contribution from ${ }^{239} \mathrm{Pu}$. The 50 -year dose commitment to the thyroid is all received during 1975 since the iodine isotopes which contribute the majority of the thyroid dose have short half-lives and the external exposure 
TABLE 26. Estimated Population Dose During 1975 from Effluents Released from Hanford Facilities During 1975

\begin{tabular}{|c|c|c|c|c|c|c|}
\hline \multirow[b]{2}{*}{ Exposure Mode } & \multicolumn{6}{|c|}{ Annual Dose (man-rem)(a) } \\
\hline & Radionuclide & Total Body & Bone & $\underline{G I-L L I}$ & Lung & Thyroid \\
\hline $\begin{array}{l}\text { Gaseous Effluent } \\
\text { Air (Inhalation and } \\
\text { Submersion) }\end{array}$ & $\begin{array}{l}H-3 \\
\text { Ar-4l } \\
\text { Sr-90+D } \\
\text { Xe-135 } \\
\text { Pu-239 } \\
\text { U-Nat }\end{array}$ & $\begin{array}{c}2.2 \times 10^{-4} \\
0.8 \\
0.02 \\
0.04 \\
3.5 \times 10^{-4} \\
3.0 \times 10^{-4}\end{array}$ & $\begin{array}{l}(0.8)^{(b)} \\
0.06 \\
(0.04) \\
7.9 \times 10^{-3} \\
2.5 \times 10^{-3}\end{array}$ & $\begin{array}{l}2.2 \times 10^{-4} \\
(0.8) \\
(0.04)\end{array}$ & $\begin{array}{c}2.2 \times 10^{-4} \\
(0.8) \\
0.26 \\
(0.04) \\
5.3 \times 10^{-2} \\
9.0 \times 10^{-2}\end{array}$ & $\begin{array}{c}2.2 \times 10^{-4} \\
(0.8) \\
(0.04)\end{array}$ \\
\hline $\begin{array}{l}\text { Radioiodine (Inhalation, } \\
\text { Milk, Vegetables) }\end{array}$ & $\begin{array}{l}I-131 \\
I-132 \\
I-133 \\
I-135\end{array}$ & & & & & $\begin{array}{c}1.03 \\
8.0 \times 10^{-4} \\
0.1 \\
0.05 \\
\end{array}$ \\
\hline Total Gaseous Pathways & & $0.86(c)$ & $0.91^{(c)}$ & $0.84(c)$ & $1.2^{(c)}$ & $2.0(\mathrm{c})$ \\
\hline $\begin{array}{l}\text { Liguid Effluent } \\
\text { Drinking water } \\
\text { Fish. Consumption } \\
\text { Aquatic Recreation } \\
\text { Irrigated Foodstuffs }\end{array}$ & $\begin{array}{l}\text { (d) } \\
\text { (d) } \\
\text { (d) } \\
\text { (d) }\end{array}$ & $\begin{array}{l}7.4 \times 10^{-3} \\
1.3 \times 10^{-3} \\
2.9 \times 10^{-3} \\
1.7 \times 10^{-4} \\
\end{array}$ & $\begin{array}{r}7.9 \times 10^{-3} \\
1.7 \times 10^{-3} \\
\left(2.9 \times 10^{-3}\right) \\
5.9 \times 10^{-4} \\
\end{array}$ & $\begin{array}{r}3.1 \times 10^{-2} \\
1.0 \times 10^{-2} \\
\left(2.9 \times 10^{-3}\right. \\
1.4 \times 10^{-3} \\
\end{array}$ & $\begin{array}{r}3.2 \times 10^{-3} \\
1.8 \times 10^{-4} \\
\left(2.9 \times 10^{-3}\right) \\
1.6 \times 10^{-4} \\
\end{array}$ & $\left.\begin{array}{c}0.7 \\
9.5 \times 10^{-3} \\
\left(2.9 \times 10^{-3}\right. \\
7.6 \times 10^{-3}\end{array}\right)$ \\
\hline Total Liquid Pathways & & $1.2 \times 10^{-2}$ & $1.3 \times 10^{-2}$ & $4.5 \times 10^{-2}$ & $6.4 \times 10^{-3}$ & 0.72 \\
\hline TOTAL & & 0.9 & 0.9 & 0.9 & 1.2 & 2. \\
\hline
\end{tabular}

(a) Dose received during 1975 from effluent released during 1975 .

(b) Internal dose from external exposure indicated by parenthesis ().

(c) Total is for all radionuclides released to the atmosphere as indicated in Table 23.

(d) Radionuclides released to the river as listed in Table 23.

sources are no longer present after 1975. The 50-year dose commitment for the G.I. tract is also all received in 1.975 since there is no accumulation of material within the tract. The estimated 50-year dose commitments to the bone and lung are 4.2 (man-bone-rem) and 2.6 (man-lung-rem), respectively. The doses received by these two organs after 1975 are due primarily to ${ }^{90} \mathrm{Sr}$ and $239 \mathrm{Pu}$ :

For comparison the population receives approximately 25,000 man-rem total body dose each year from background radiation (total: external plus internal). The dose received by the population during 1975 from Hanford operations was an addition of about $0.004 \%$ of the background dose. Assuming the people within 80 kilometers of the Hanford Reservation are typical of the national average, they probably received total body population doses of 5,100 man-rem 
TABLE 27. Estimated 50-Year Population Dose Commitment from Effluents Released from Hanford Facilities During 1975

\begin{tabular}{|c|c|c|c|c|c|c|}
\hline \multirow[b]{2}{*}{ Exposure Mode } & \multicolumn{6}{|c|}{ Dose Commitment (man-rem)(a) } \\
\hline & Radionuclide & Total Body & Bone & $\underline{\text { GI-LLI }}$ & Lung & Thyroid \\
\hline $\begin{array}{l}\text { Gaseous Effluent } \\
\text { Air (Inhalation and } \\
\text { Submersion) }\end{array}$ & $\begin{array}{l}\mathrm{H}-3 \text { (HTO) } \\
\mathrm{Ar}-41 \\
\mathrm{Sr}-90+\mathrm{D} \\
\mathrm{Xe}-135 \\
\mathrm{Pu}-239 \\
\text { U-Nat }\end{array}$ & $\begin{array}{c}2.2 \times 10^{-4} \\
0.8 \\
0.63 \\
0.04 \\
0.04 \\
5.6 \times 10^{-4}\end{array}$ & $\begin{array}{c}(0.8)(b) \\
2.6 \\
(0.04) \\
0.8 \\
9.0 \times 10^{-3}\end{array}$ & $\begin{array}{c}2.2 \times 10^{-4} \\
(0.8) \\
-- \\
(0.04) \\
\cdots-\end{array}$ & $\begin{array}{c}2.2 \times 10^{-4} \\
(0.8) \\
1.1 \\
(0.04) \\
0.24 \\
0.42\end{array}$ & $\begin{array}{c}2.2 \times 10^{-4} \\
(0.8) \\
\cdots \\
(0.04) \\
\cdots-\end{array}$ \\
\hline $\begin{array}{l}\text { Radioíodine (Inhalation, } \\
\text { Milk, Vegetables }\end{array}$ & $\begin{array}{l}I-131 \\
I-132 \\
I-133 \\
I-135\end{array}$ & & & . & & $\begin{array}{c}1.03 \\
8.0 \times 10^{-4} \\
0.1 \\
0.05 \\
\end{array}$ \\
\hline Total Gaseous Pathways & & 1.5 & 4.2 & 0.8 & 2.6 & 2.0 \\
\hline $\begin{array}{l}\text { Liquid Effluent } \\
\text { Drinking Water } \\
\text { Fish Consumption } \\
\text { Aquatic Recreation } \\
\text { Irrigated Foodstuffs }\end{array}$ & $\begin{array}{l}\text { (d) } \\
\text { (d) } \\
\text { (d) }\end{array}$ & $\begin{array}{l}2.3 \times 10^{-2} \\
2.9 \times 10^{-3} \\
3.0 \times 10^{-3} \\
2.8 \times 10^{-3} \\
\end{array}$ & $\begin{array}{r}6.4 \times 10^{-2} \\
8.2 \times 10^{-3} \\
\left(3.0 \times 10^{-3}\right) \\
\left.. .6 \times 10^{-2}\right) \\
\end{array}$ & $\begin{array}{r}6.5 \times 10^{-2} \\
1.0 \times 10^{-2} \\
\left(3.0 \times 10^{-3}\right) \\
1.0 \times 10^{-2} \\
\end{array}$ & $\begin{array}{r}3.2 \times 10^{-3} \\
2.0 \times 10^{-4} \\
\left(3.0 \times 10^{-3}\right) \\
1.6 \times 10^{-4} \\
\end{array}$ & $\begin{array}{r}0.7 \\
9.5 \times 10^{-3} \\
\left(3.0 \times 10^{-3}\right. \\
6.3 \times 10^{-2} \\
\end{array}$ \\
\hline Total Liquid Pathways & & $3.2 \times 10^{-2}$ & $9.1 \times 10^{-2}$ & $8.8 \times 10^{-2}$ & $6.6 \times 10^{-3}$ & 0.78 \\
\hline TOTAL & & 1.5 & 4.2 & 0.9 & 2.6 & 2.8 \\
\hline
\end{tabular}

(a) Dose commitment for 50 years (1975-2024, inclusive) from effluents released during 1975.

(b) Internal dose from external exposure indicated by parenthesis ( ).

(c) Total is for all radionuclides released to the atmosphere as indicated in Table 23 .

(d) Radionuclides released to the river as listed in Table 23.

from medical exposures, 250 man-rem from jet air trave1, 25 man-rem from television receivers, and 370 man-rem from miscellaneous consumer products during 1975.12

In summary, the maximum "fence-post" exposure rate was calculated to be $6 \times 10^{-6} \mathrm{mR} / \mathrm{hr}$ along the northwest boundary of the Hanford site. The total body dose received by the maximum individual during 1975 and the 50-year dose commitment from effluent released during 1975 are 0.01 mrem and 0.02 mrem, respectively: The total-body dose potentially received by the assumed 250,000 people living within an 80 kilometer radius of the Hanford site during 1975 and the 50-year, dose commitment from effluents released during 
197.5 are 0.9 man-rem and 1.5 man-rem, respectively. For comparison, the total background dose (external and internal) received by all members of the population in the Hanford region is approximately 100 mrem per year, resulting in a population dose of 25,000 man-rem.

RADIOLOGICAL IMPACT FROM OBSERVED RADIOACTIVITY DUE TO PAST HANFORD OPERATIONS

Previous sections (Columbia River, Wildlife, Soil and Vegetation) concerned with the evaluation of monitoring data collected during 1975 discussed the presence of radioactivity, primarily ${ }^{60} \mathrm{Co}$, in Columbia River sediments, wildlife, and soil on the Columbia River islands due to past once-through cooling production reactor operation at Hanford. The last of these reactors was deactivated in January 1971. Radioactivity released to the river from these reactors became attached to sediments in the river. The observed radioactivity has steadily decreased due to radioactive decay and dilution. During the spring of 1974, an aerial survey of the Columbia River shoreline and islands was conducted by EG\&G of Las Vegas, Nevada. ${ }^{9}$ This survey covered an area from approximately four kilometers above Vernita Bridge to approximately ten kilometers below. the intersection of the Snake River with the Columbia River. The highest radiation level observed offsite during this survey occurred on the islands between the old Hanford townsite and the 300 Area. A maximum reading of $0.014 \mathrm{mR} / \mathrm{hr}$ of ${ }^{60} \mathrm{Co}$ was obtained. This exposure rate will have decreased since 1974 due to radioactive decay ( ${ }^{60} \mathrm{Co}_{0}$ has a 5.3 year halflife) and dilution by the river. However, since no measurement was made in 1975, the 1974 value of $0.014 \mathrm{mR} / \mathrm{hr}$ is assumed to be still applicable.

During 1975, the levels in fish and gamebirds were occasionally detected at levels near the detection limit of the analyses. Levels of ${ }^{65} \mathrm{Zn}$ in Willapa Bay nysters continued to decrease and are now five-hundred-fold less than during the early part of 1970. The majority of radioactivity observed in Columbia River water due to past Hanford operations is attached to resuspended sediment, and the levels observed during 1975 were generally lower than those observed during 1974. 
The contribution of these sources of radioactivity to the maximum "fencepost" exposure rate, maximum individual dose, and 80-kilometer population dose calculated from 1975 effluent, range from insignificant to predominant. The maximum "fence-post" exposure rate calculated from 1975 effluent was $6 \times 10^{-6} \mathrm{mR} / \mathrm{hr}$ along the uninhabited northwest boundary of the Hanford site. The highest external exposure rate measured on the Columbia River islands 9 was much greater than the exposure rate calculated for the northwest boundary. The contribution of the radioactivity observed on some of the islands to the dose received by an individual would depend on the amount of time spent by the individual on the islands and where the time was spent. The distribution of radioactivity on the islands from Hanford operations is quite variable. Assuming an individual was at the point of highest observed external exposure rate, an external dose of approximately $0.014 \mathrm{mrem} / \mathrm{hr}$ would be received in addition to background external radiation. It is unlikely that anyone would spend more than a few hours each year on the islands. The contribution to the population dose received during 1975 is an insignificant numerical addition to the previously calculated dose of 0.9 man-rem from 1975 effluents due to the low levels of radioactivity involved, the remoteness of the islands, and the small number of people potentially affected. 
STANDARDS.

Operations at the Hanford site must conform to a variety of Federal and State standards designed to insure the radiological, chemical, biological, and physical quality of the environment for either aesthetic or public health considerations. The State of Washington has promulgated water quality standards for the Columbia River. ${ }^{2}$ of interest to Hanford operations is the designation of the Hanford reach of the Columbia River as Class A or excellent. This designation requires the water to be usable for substantially all needs including sanitary water, recreation, and wildlife. Air quality standards have been promulgated by both the State of Washington ${ }^{2}$ and the EPA. 3

Environmental radiation protection standards are published in Manual Chapter 0524, "Standards for Radiation Protection"l of ERDA. These standards are based on guidelines recommended by the President's Federal Radiation Council (FRC), whose functions have been assigned to the EPA, and other scientific groups such as the International Commission on Radiological Protection (ICRP) and the National Commission on Radiation Protection and Measurements (NCRP). The standards govern ionizing radiation exposure to ERDA and ERDA contractor personnel and to members of the public who may be exposed to ionizing radiation resulting from ERDA and ERDA contractor operations.

Copies of these regulations may be obtained from the following organizations:

(1) State of Washington

Department of Ecology

Olympia, WA 98504

(2) U. S. Environmental Protection Agency, Region 10 1200 Sixth Avenue

Seattle, WA 98101

(3) Energy Research and Development Adminislratiun Richland Operations Office

P. 0. Box 999

Richland, WA 99352 


\section{ACKNOWLEDGMENT}

Acknowledgment is given to several other people who participated in the preparation of this report. Loren Maas of HEHF supplied data regarding radiological analyses of air and sanitary water. Harold Oens supplied data regarding $U$. S. Testing Company participation in the EPA Interlaboratory Comparison Program for environmental sample analyses (Appendix $B$ ). Ed Watson and Dennis Strenge performed the atmospheric dose calculations. Joe Soldat performed all other dose calculations appearing in the tables, contained in the "Radiological Impact" section. Lonnie Foley edited the report and Carolyn Schauls typed it. 


\section{REFERENCES}

1. "Standards for Radiation Protection," ERDA Manual, Chapter 0524, with Appendix. U.S. Energy Research and Development Administration, Washington, DC, 1963. REvised October 1973.

2. Water Quality Standards; Department of Ecology, State of Washington, June 1973.

3. "Natural Primary and Secondary Ambient Air Quality Standards," Federal Regulations, 40 CFR 50, Environmental Protection Agency, January 1973.

4. U.S. Environmental Protection Agency, Estimates of Ionizing Radiation Doses in the United States 1960 - 2000, ORP/CSD 72-1, Rockvil7e, MD, August 1972.

5. J: J. Fix and D. E. Roberts, A "Filter-Resin" Sampling Method for Measurement of RAdioactivity in Columbia River Water, BNWL-SA-5630, Battelle-Northwest, Richland, WA, January 1976.

6. Drinking Water Standards - 1962, Public Health Service, Washington, DC, 1962.

7. R. T. Jaske and M. R. Synogrud, Effect of Hanford Plant Operations on the Temperature of the Columbia River, 1964 to Present, BNWL-1345, Battelle-Northwest, Richland, WA, November 1970.

8. J. R. Raymond, et al., Radiological Status of the Groundwater Beneath the Hanford Project - January-December 1974, BNWL-1970, BattelleNorthwest, Richland, WA.

9. W. J. Tipton, An Aerial Radiological Survey of the U.S. Atomic Energy Commission's Hanford Reservation, EG\&G, Las Vegas, NV, in press.

10. J. J. Fix, Association of Long-Lived Radioactivity with Sediment Along the Columbia River Shoreline, Islands, Bottom, and Slough Areas, presented at the ERDA Third Environmental Protection Conference, Chicago, IL, September 1975, CONF-750967, pp 389-417.

11. D. H. Denham, et al., A CaF2:Dy Thermoluminescent Dosimeter for Environmental Monitoring, BNWL-SA-4191, Battelle-Northwest, Richland, WA, August 1972.

12. D. T. Oakley, Natural Radiation Exposure in the United States, ORP/SID 72-1; Environmental Protection Agency, Washington DC, June 1972.

13. J. J. Fix, Environmental Surveillance at Hanford for CY-1974, BNWL-1910, Battelle-Northwest, Richland, WA, April 1975 
14. L. L. Philipp and E. M. Sheen, Aerial and Ground Gamma Survey Monitors, BNWL-62, Battelle-Northwest, Richland, WA (May 1965).

15. J. K. Soldat, et al., Models and Computer Codes for Evaluating Environmental Radiation Doses, BNWL-1754, Battelle-Northwest, Richland, WA, February 1974.

16. D. L. Strenge and E. C. Watson, KRONIC -.. A Computer Program for Calculating Annual Average External Doses from Chronic Atmospheric Releases of Radionuclides, BNWL-B-264, Battelle-Northwest, Richland, WA, June 1973.

17. U. S. Energy Kesearch and Development Admintstration, Hanfurd Wasle Management Operations Environmental Impact Statement, ERDA-1538, ERDA Hanford Operations, December, 1975.

18. "Effluents and Environmental Monitoring and Reporting," ERDA Manual, Chapter 0513, U. S. Energy Research and Uevelopment Administration, March 1972, Revised February 1974. 
APPENDIX A

SYNOPSIS OF FILTER-RESIN SAMPLING METHOD 


\section{SYNOPSIS OF FILTER-RESIN SAMPLING METHOD}

This method involves running a known quantity of river water through a nylon filter, a series of fiberglass filters, and a mixed-bed ion exchange column. The sampler operates continuously during which the river water flows ( 23 liters/hour) through the nylon filter which removes all macro ( $>5$ microns) particles, through the series of fiberglass filters which remove all particles greater than 0.3 microns, and then the filtered water flows through the resin to remove all soluble radionuclides with the exception of tritium. The filters and resin are changed biweekly and directly counted with a high sensitivity multi-dimensional (coincidence) gamma ray spectrometer to measure the different radionuclides. This method results in a much lower detection level and separates the collected radioactivity into a particulate fraction (collected on filters) and a soluble fraction (absorbed on resin). 
APPENDIX B

RADIOCHEMICAL ANALYSES 
APPENDIX B

\section{RADIOCHEMICAL ANALYSES}

The majority of the routine environmental radioanalyses for the Hanford program are performed by the U. S. Testing Company in Richland, Washington. Analytical limits are specified in a services contract between U. S. Testing and the Energy Research and Development Administration (ERDA). The term "analytical limit" is contractually defined as the concentration at which the laboratory can measure a radionuclide with an accuracy of $\pm 100 \%$ at the $90 \%$ confidence level given the required volume of sample material. The detection limit for a specific radionuclide varies with sample type, sample size, counting time, and amounts of interfering radionuclides present. The "analytical limits" represent upper bounds to the fluctuating detection limits.

U. S. Testing maintains an internal quality control program consisting of routine instrument calibration and background counts to insure the integrity of their results. They also participate in the Interlaboratory Comparison program of the Environmental Protection Agency (EPA) involving the analysis of several environmental media (milk, water and air) and a variety of radionuclides of interest. A number of different environmental samples, containing known amounts of one or more radionuclides, are prepared and routinely distributed to all laboratories in the program. These laboratories perform the required analyses ( 3 separate determinations) and return their results to EPA for comparison with the known value and the results from the other laboratories. If there is an error in the preparation of any sample, the results from the different laboratories should form a consensus around the correct value. In this manner, the program enables a laboratory to document the precision and accuracy of their results relative to the other laboratories.

The data in the following table and figures have been supplied by U. S. Testing and provide a comparison between their reported results, the results from other laboratories, and the EPA value for each analysis. The EPA samples are generally at least a factor of 10, and in some cases 1000 , 
higher than the routine environmental samples. Since the preparation and analysis of environmental samples with levels of radioactivity near the background levels present in the environment is quite difficult, the requirement for extensive data to prevent unrealistic reliance on any single result is of particular importance. 
TABLE B-1. Interlaboratory Comparison of Analytical Results(a)

\begin{tabular}{|c|c|c|c|c|c|}
\hline \multirow[b]{2}{*}{ Medium } & \multirow[b]{2}{*}{ Date } & \multirow[b]{2}{*}{ Isotope } & \multicolumn{3}{|c|}{ Concentration $(b)$} \\
\hline & & & $\underline{U S T}{ }^{(c, d)}$ & Expected $(d)$ & $\begin{array}{l}\text { Other }(e) \\
\text { Labs } \\
\end{array}$ \\
\hline \multirow[t]{4}{*}{ Milk } & $1 / 15 / 75$ & $\begin{array}{l}40 \mathrm{~K} \\
90 \mathrm{Sr} \\
131 \mathrm{I} \\
137 \mathrm{CS}\end{array}$ & $\begin{array}{c}1370 \pm 210 \\
70 \pm 5.0 \\
100 \pm 60 \\
90 \pm 45\end{array}$ & $\begin{array}{c}1510 \pm 228 \\
75 \pm 11.4 \\
101 \pm 15.3 \\
75 \pm 15\end{array}$ & $\begin{array}{c}1486 \pm 330 \\
71 \pm 30 \\
104 \pm 24 \\
77 \pm 27\end{array}$ \\
\hline & $3 / 14 / 75$ & $\begin{array}{l}40 \mathrm{~K} \\
89 \mathrm{Sr} \\
90 \mathrm{Sr} \\
131 \mathrm{I} \\
137 \mathrm{Cs}\end{array}$ & $\begin{array}{c}1575 \pm 240 \\
0 \pm 8 \\
39 \pm 5.0 \\
84 \pm 96 \\
51 \pm 44\end{array}$ & $\begin{array}{c}1514 \pm 228 \\
(f) \\
50 \pm 7.5 \\
76 \pm 15 \\
50 \pm 75\end{array}$ & $\begin{array}{c}1504 \pm 330 \\
\cdot 47 \pm 33 \\
79 \pm 33 \\
53 \pm 18\end{array}$ \\
\hline & $5 / 9 / 75$ & $\begin{array}{l}40 \mathrm{~K} \\
90 \mathrm{Sr} \\
131 \mathrm{I} \\
137 \mathrm{Cs}\end{array}$ & $\begin{array}{c}1588 \pm 240 \\
26 \pm 4.0 \\
29 \pm 96 \\
22 \pm 44\end{array}$ & $\begin{array}{c}1514 \pm 228 \\
25 \pm 4.5 \\
49.8 \pm 75 \\
24.9 \pm 15\end{array}$ & $\begin{array}{c}1525 \pm 264 \\
23 \pm 12.0 \\
47 \pm 21 \\
27 \pm 12\end{array}$ \\
\hline & $11 / 7 / 75$ & $\begin{array}{l}40 \mathrm{~K} \\
89 \mathrm{Sr} \\
90 \mathrm{Sr} \\
131 \mathrm{I} \\
137 \mathrm{CS}\end{array}$ & $\begin{array}{c}1500 \pm 225 \\
34 \pm 15 \\
77 \pm 6 \\
72 \pm 96 \\
69 \pm 60\end{array}$ & $\begin{array}{c}1549 \pm 233 \\
(f) \\
74.6 \pm 11.2 \\
75 \pm 15 \\
75 \pm 15\end{array}$ & $\begin{array}{c}1528 \pm 369 \\
71 \pm 21 \\
74 \pm 30 \\
77 \pm 21\end{array}$ \\
\hline \multirow[t]{4}{*}{ Air Filter } & $2 / 28 / 75$ & $\begin{array}{l}90 \mathrm{Sr} \\
137 \mathrm{Cs} \\
\text { Alpha } \\
\text { Beta }\end{array}$ & $\begin{array}{l}140 \pm 9 \\
162 \pm 30 \\
148 \pm 9 \\
542 \pm 19\end{array}$ & $\begin{array}{c}159 \pm 24 \\
151 \pm 22.5 \\
149.5 \pm 112.2 \\
470 \pm 72\end{array}$ & $\begin{array}{l}164 \pm 72 \\
161 \pm 57 \\
144 \pm 126 \\
506 \pm 210\end{array}$ \\
\hline & $6 / 27 / 75$ & $\begin{array}{l}137 \mathrm{Cs} \\
\text { Alpha } \\
\text { Beta }\end{array}$ & $\begin{array}{l}143 \pm 27 \\
109 \pm 8 \\
379 \pm 9\end{array}$ & $\begin{array}{l}135 \pm 26 \\
123 \pm 92 \\
371 \pm 56\end{array}$ & $\begin{array}{l}142 \pm 51 \\
128 \pm 78 \\
389 \pm 132\end{array}$ \\
\hline & $9 / 19 / 75$ & $\begin{array}{l}137 \mathrm{Cs} \\
\text { Alpha } \\
\text { Beta }\end{array}$ & $\begin{array}{c}83 \pm 23 \\
62 \pm 5.5 \\
266 \pm 12\end{array}$ & $\begin{array}{c}99 \pm 15 \\
99 \pm 74.3 \\
295 \pm 44\end{array}$ & $\begin{array}{r}96 \pm 33 \\
89 \pm 66 \\
304 \pm 87\end{array}$ \\
\hline & $12 / 26 / 75$ & $\begin{array}{l}90 \mathrm{Sr} \\
13^{7} \mathrm{Cs} \\
\text { Alpha } \\
\text { Beta }\end{array}$ & $\begin{array}{l}33.5 \pm 4 \\
24.7 \pm 23 \\
33.4 \pm 4.4 \\
109 \pm 10\end{array}$ & $\begin{array}{l}38 \pm 5.7 \\
25 \pm 15 \\
38 \pm 28.5 \\
101 \pm 15\end{array}$ & $\begin{array}{r}36 \pm 21 \\
28 \pm 21 \\
40 \pm 21 \\
107 \pm 24\end{array}$ \\
\hline
\end{tabular}


TABLE B-1. (Cont.)

Medium

Water

\begin{tabular}{|c|c|}
\hline Date & I sotop \\
\hline $1 / 31 / 75$ & $\begin{array}{l}\text { Alpha } \\
\text { Beta }\end{array}$ \\
\hline $2 / 14 / 75$ & $3 \mathrm{H}$ \\
\hline $2 / 21 / 75$ & $\begin{array}{r}00 \mathrm{Co} \\
65 \mathrm{Zn} \\
106 \mathrm{Ru} \\
134 \mathrm{Cs} \\
137 \mathrm{Cs}\end{array}$ \\
\hline
\end{tabular}

$3 / 28 / 75$

Alpha Beta

$4 / 11 / 75$

$4 / 18 / 75$

$$
\begin{gathered}
{ }^{3} \mathrm{H} \\
{ }^{60} \mathrm{Co} \\
65 \mathrm{Zn} \\
106 \mathrm{Ru} \\
13^{14} \mathrm{Cs} \\
{ }^{13} \mathrm{Cs}
\end{gathered}
$$

$5 / 30 / 75$

Alpha Beta

$6 / 13 / 75$

$6 / 20 / 75$

$$
\begin{array}{r}
{ }^{3} \mathrm{H} \\
{ }^{60} \mathrm{Co} \\
65 \mathrm{Zn} \\
106 \mathrm{Ru} \\
1.34 \mathrm{Cs} \\
1{ }^{37} \mathrm{Cs}
\end{array}
$$

$7 / 25 / 75$

$8 / 15 / 75$

$8 / 22 / 75$

Alpha

Beta

${ }^{3 H}$

\begin{tabular}{|c|c|c|}
\hline$\underline{U S T}(c, d)$ & Expected $(\mathrm{d})$ & $\begin{array}{l}\text { Other }(\mathrm{e}) \\
\text { Labs }\end{array}$ \\
\hline $\begin{array}{l}18 \pm 6 \\
69 \pm 13\end{array}$ & $\begin{array}{l}25 \pm 19 \\
95 \pm 15\end{array}$ & $97 \pm$ \\
\hline
\end{tabular}

$$
\begin{aligned}
& { }^{51} \mathrm{Cr} \\
& 60 \mathrm{Co} \\
& 65 \mathrm{Zn}
\end{aligned}
$$

$106 \mathrm{Ru}$

${ }_{134} \mathrm{Cs}$

${ }^{137} \mathrm{CS}$

Concentration (b)

$3027 \pm 470$

$327 \pm 163$

$458 \pm 83$

$276 \pm 285$

$475 \pm 270$

$420 \pm 45$

$93 \pm 19$

$23 \pm 8$

$2490 \pm 467$

$366 \pm 33$

$424 \pm 195$

$491 \pm 270$

$272 \pm 68$

$402 \pm 38$

$$
\begin{gathered}
2803 \pm 1050 \\
437 \pm 66 \\
472 \pm 71 \\
(f) \\
422 \pm 63 \\
472 \pm 71
\end{gathered}
$$

$2796 \pm 903$

$443 \pm 75$

$481 \pm 180$

$418 \pm 150$

$473 \pm 132$

$98 \pm 76.5$

$26 \pm 15$

$76 \pm 90$

$39 \pm 36$

$1499 \pm 1002$

$1549 \pm 525$

$425 \pm 64$

$497 \pm 75$

$497 \pm 75$

$400 \pm 60$

$450 \pm 68$

$425 \pm 93$

$502 \pm 147$

$495 \pm 756$

$407 \pm 93$

$455 \pm 111$

$45 \pm 8$

$40 \_30$

$60 \pm 15$

$32 \pm 12$

$63 \pm 42$

$2591 \pm 600$

$2204 \pm 1044$

$2184 \pm 951$

$287 \pm 32$

$308 \pm 48$

$373 \pm 72$

$251+23$

$239 \pm 26$

$86 \pm 10$

$9 \pm 8$

$350 \pm 53$

$327 \pm 49$

$325 \pm 49$

$304 \pm 46$

$378 \pm 57$

$341 \pm 123$

$349 \pm 63$

$334 \pm 129$

$302 \pm 75$

$382 \pm 78$

$85.7 \pm 64.3 \quad 65 \pm 63$

$2193 \pm 225$

$513 \pm 375$

$581 \pm 129$

$533 \pm 180$

$616 \pm 300$

$404 \pm 105$

$391 \pm 90$ (f)

$3200 \pm 1083$

$255 \pm 38$

$307 \pm 46$

$281 \pm 42$

$379+57$

$256 \pm 38$

$305 \pm 29$
$3185 \pm 882$

$278 \pm 177$

$305 \pm 66$

$293 \pm 111$

$369 \pm 180$

$254 \pm 27$

$307 \pm 46$. 
TABLE B-1. (Cont.)

\begin{tabular}{|c|c|c|c|c|c|}
\hline \multirow[b]{2}{*}{ Medium } & \multirow[b]{2}{*}{ Date } & \multirow[b]{2}{*}{ Isotope } & \multicolumn{3}{|c|}{ Concentration $(b)$} \\
\hline & & & $\underline{U S T} T^{(c, d)}$ & Expected $^{(d)}$ & $\begin{array}{l}\text { Other } \\
\text { Labs }\end{array}$ \\
\hline Water & $9 / 26 / 75$ & $\begin{array}{l}\text { Alpha } \\
\text { Beta }\end{array}$ & $\begin{array}{l}.0 .35 \pm 3.0 \\
40 \pm 15\end{array}$ & $\begin{array}{c}(f) \\
52 \pm 15\end{array}$ & $49 \pm 21$ \\
\hline & $10 / 17 / 75$ & ${ }^{3} \mathrm{H}$ & $1130 \pm 450$ & $1203 \pm 975$ & $1304 \pm 837$ \\
\hline & $10 / 24 / 75$ & $\begin{array}{l}{ }^{60} \mathrm{Co} \\
{ }^{65} \mathrm{Zn} \\
106 \mathrm{Ru} \\
134 \mathrm{Cs} \\
137 \mathrm{Cs}\end{array}$ & $\begin{array}{l}225 \pm 38 \\
202 \pm 60 \\
181 \pm 270 \\
250 \pm 117 \\
177 \pm 38\end{array}$ & $\begin{array}{l}271 \pm 41 \\
250 \pm 38 \\
247 \pm 37 \\
349 \pm 52 \\
274 \pm 41\end{array}$ & $\begin{array}{l}277 \pm 39 \\
250 \pm 99 \\
259 \pm 108 \\
344 \pm 66 \\
275 \pm 69\end{array}$ \\
\hline & $11 / 21 / 75$ & $\begin{array}{l}\text { Alpha } \\
\text { Beta }\end{array}$ & $\begin{array}{l}28 \pm 7 \\
59 \pm 18\end{array}$ & $\begin{array}{l}31 \pm 23 \\
31 \pm 15\end{array}$ & $\begin{array}{l}27 \pm 24 \\
34 \pm 18\end{array}$ \\
\hline & $12 / 19 / 75$ & $\begin{array}{l}{ }^{60} \mathrm{Co} \\
{ }^{65} \mathrm{Zn} \\
106 \mathrm{Ru} \\
134 \mathrm{Cs} \\
137 \mathrm{Cs}\end{array}$ & $\begin{array}{l}151 \pm 30 \\
154 \pm 57 \\
190 \pm 270 \\
188 \pm 117 \\
123 \pm 32\end{array}$ & $\begin{array}{l}203 \pm 31 \\
201 \pm 30 \\
181 \pm 27 \\
202 \pm 30 \\
151 \pm 23\end{array}$ & $\begin{array}{l}206 \pm 51 \\
201 \pm 87 \\
191 \pm 90 \\
195 \pm 51 \\
153 \pm 51\end{array}$ \\
\hline
\end{tabular}

(a) The Environmental Protection Agency prepares spiked samples and distributes them to radiochemistry laboratories who wish to participate in the interlaboratory comparisons.

(b) PicoCuries per liter for water and milk; picoCuries per sample for air.

(c) United States Testing Co., Richland, Washington.

(d) Concentration plus or minus three sigma based on counting statistics.

(e) Average concentration plus or minus three sigma based upon range of values encountered.

(f) Sample was not spiked with the nuclide. 
The following tables demonstrate the relative accuracy of analyses by U. S. Testing of various isotopes in air, water and milk at the three sigma $(99.9 \%)$ confidence level.

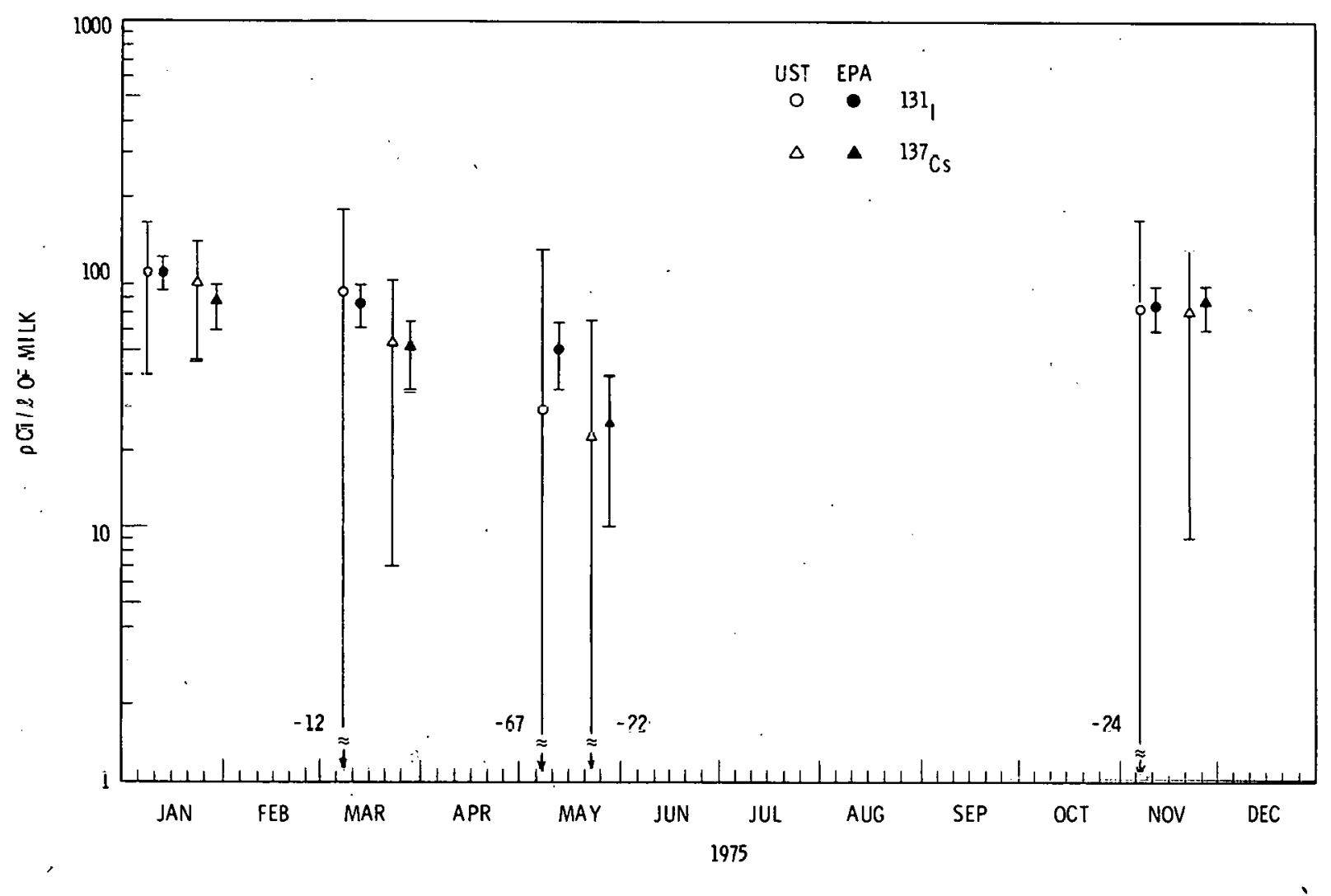



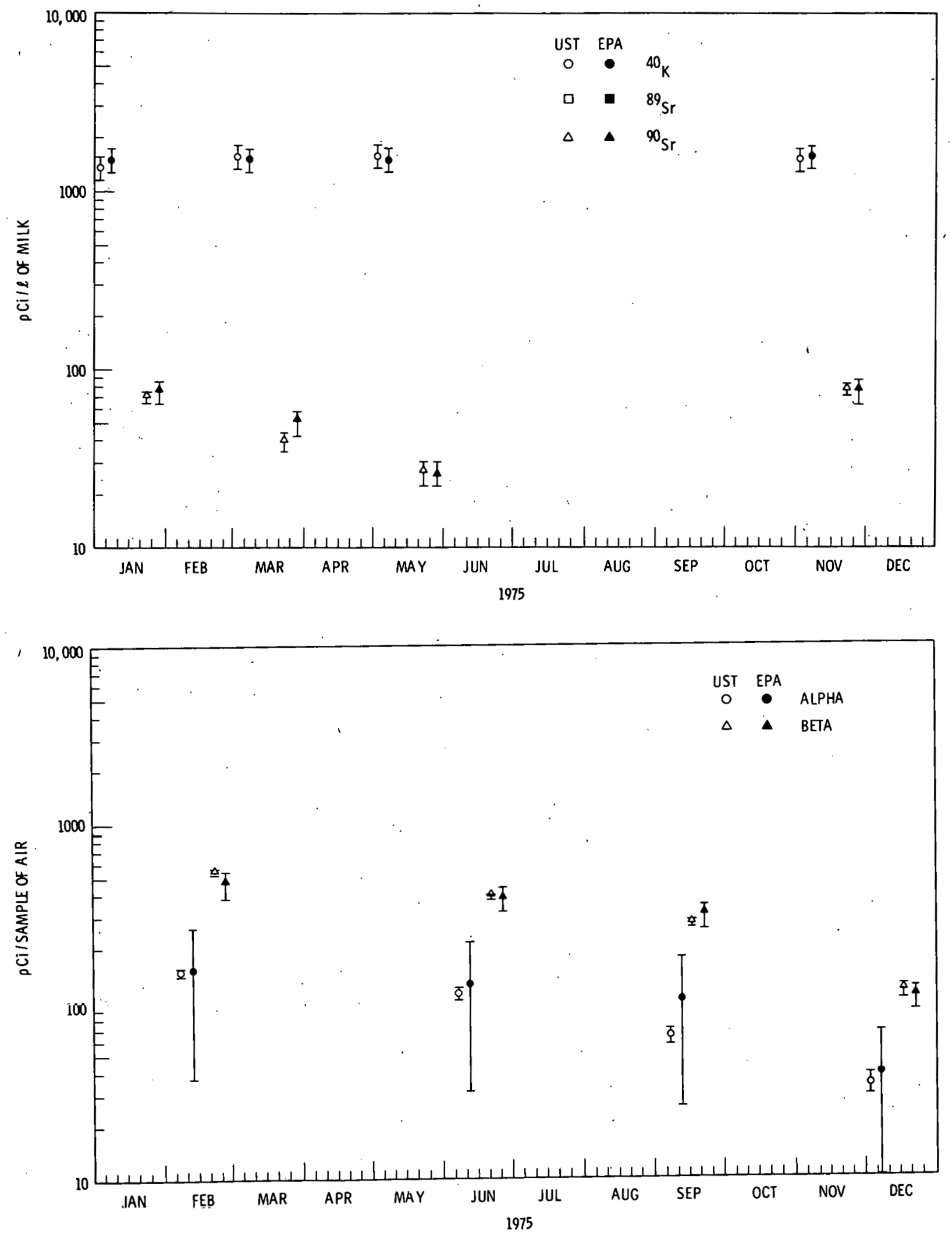

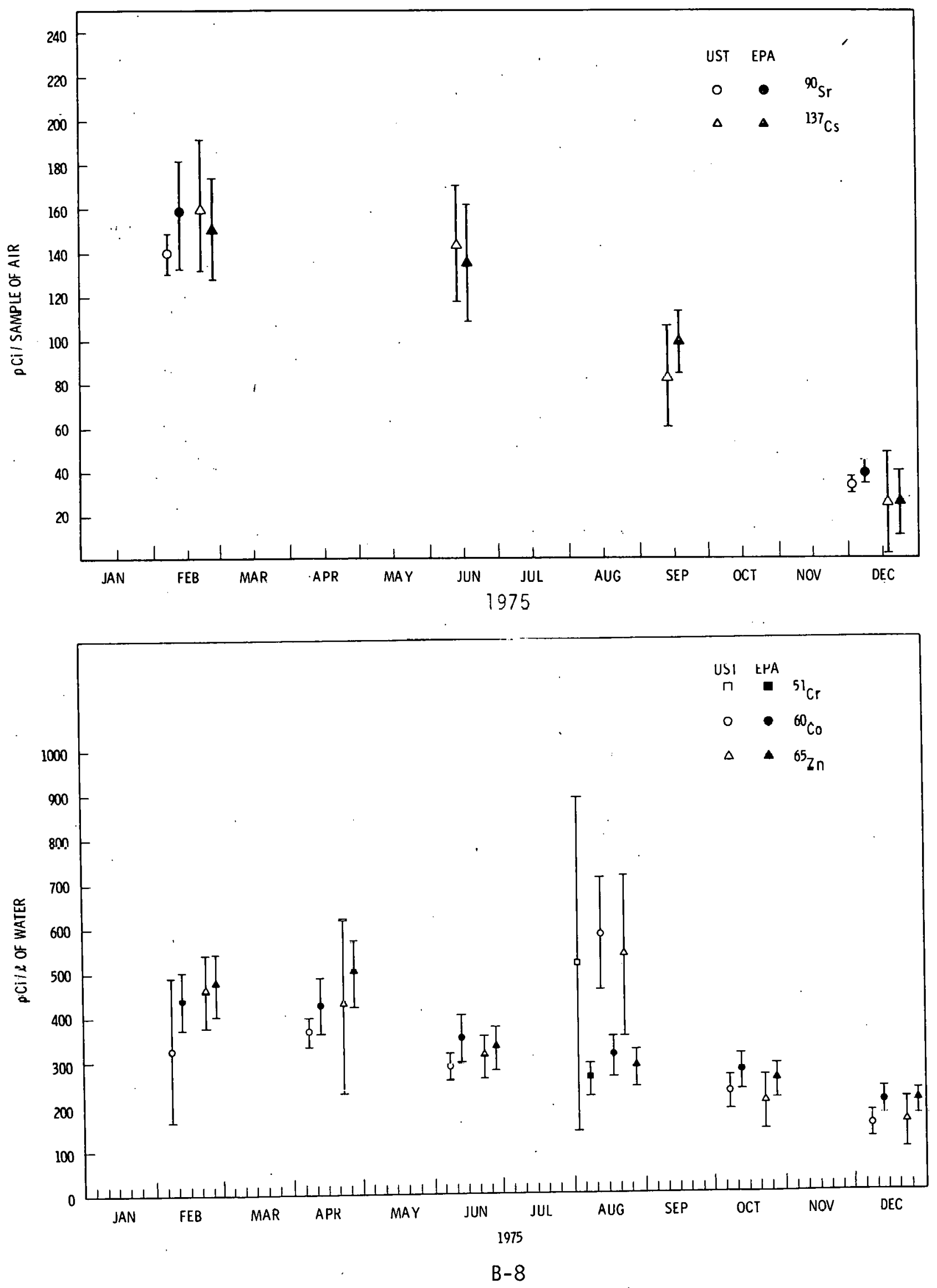

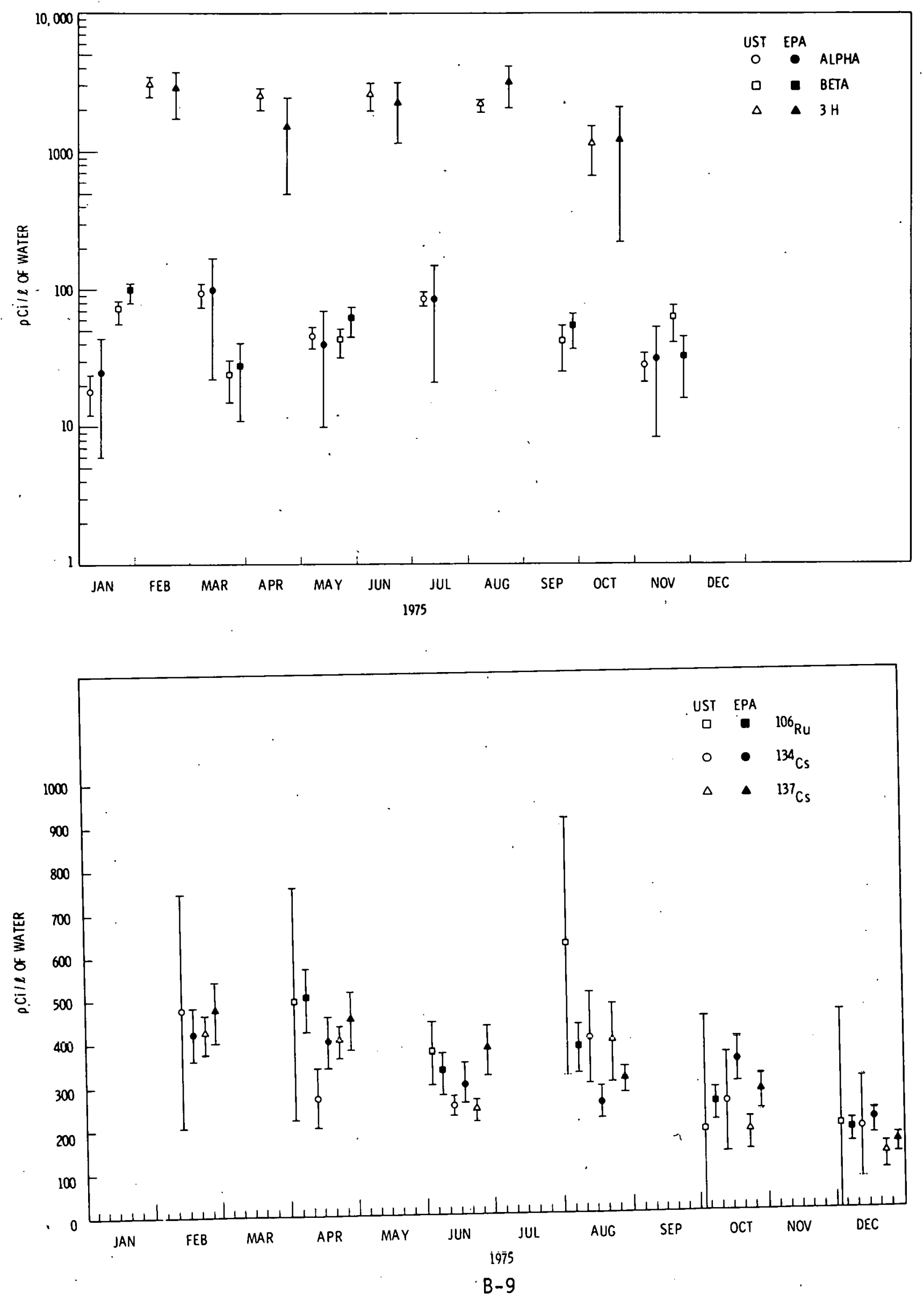
APPENDIX C

HANFORD ENVIRONMENTAL HEALTH FOUNDATION'S CHEMISTRY LABORATORY CERTIFICATION 


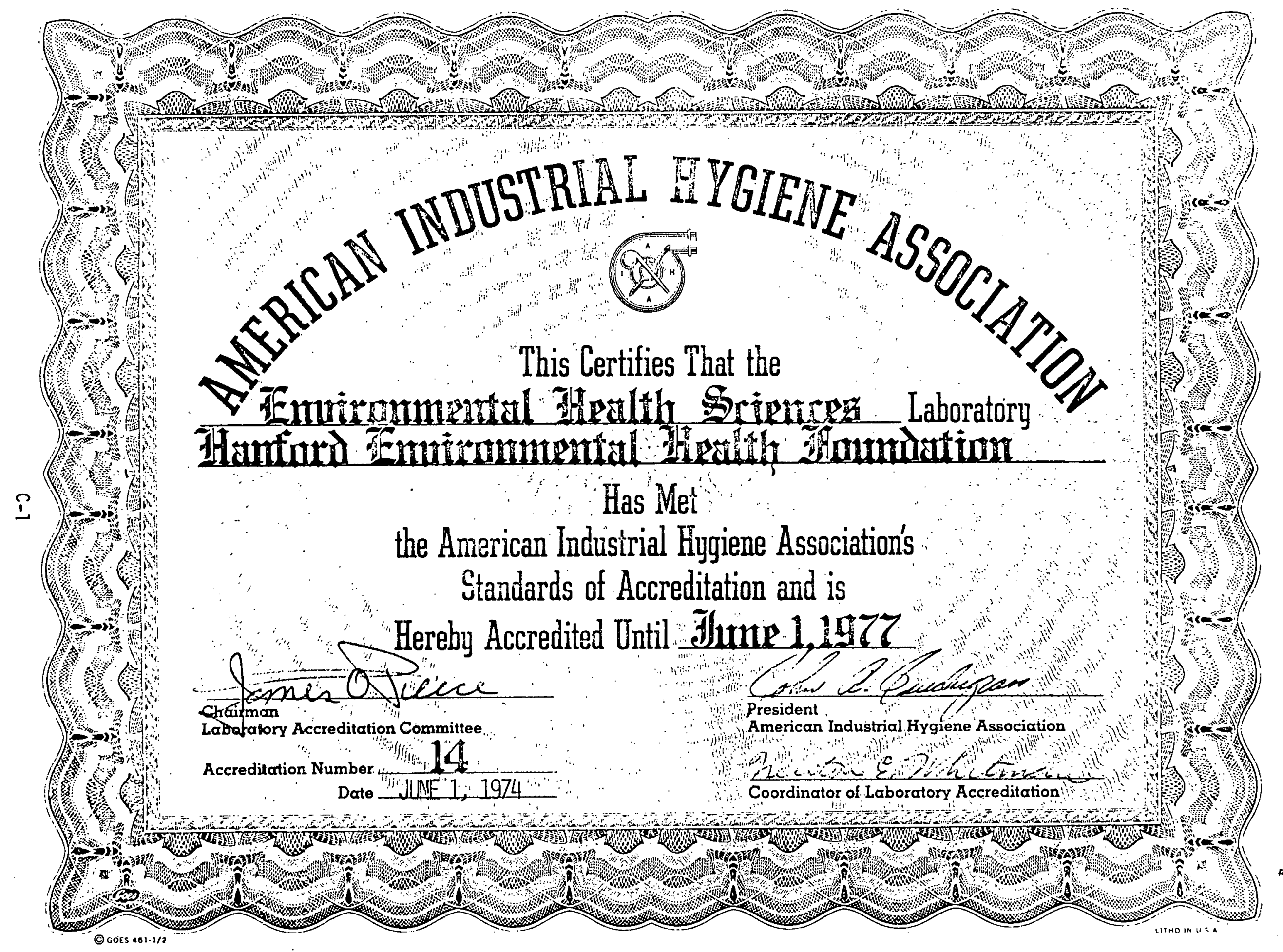




\section{APPENDIX D}

GLOSSARY OF TERMS 


\section{APPENDIX D}

\section{Glossary of Terms}

Analytical detection limit: That value below which a concentration of a contaminant cannot be determined with at least a $95 \%$ accuracy; usually 3 times the background level of the contaminant.

BOD: Biochemical 0xygen Demand is the oxygen required during stablization of the decomposable organic matter by aerobic bacterial action in water or wastewater.

Coliform: All microorganisms that ferment lactose and produce gas. Used herein as an indicator for the possible presence of sewage in water.

Curie ( $\mathrm{C} i)$ : The special unit of radioactivity. One curie equals $3.700 \times 10^{10}$ nuclear transformations per second.

Dosimeter: A device for measuring the quantity of radiation or energy absorbed.

Effluent: Material released from a facility in one of its waste streams. Usualiy refers to non-natural waste material streams such as carbon dioxide or Cobalt-60.

Enterococci: That group of bacteria normally found in the intestine of man and animals. Used herein as a positive indicator of sewage contamination of waters.

Micro ( $\mu)$ : A prefix meaning one millionth of.

Milli (m): A prefix meaning one thousandth of.

Nitrate: Any compound containing the univalent group - $\mathrm{ONO}_{2}$ or $\mathrm{NO}_{3}$; used here to refer to the presence of untreated sewage or commercial fertilizer residue from agricultural practices.

$\mathrm{pH}$ : A measure of the acidity or alkalinity of a water solution; neutral is 7 , acids are less than 7 and alkalies are greater than 7 .

Pico $(p)$ : A prefix meaning one million millonths of.

Rad: The unit of absorbed radiation dose equal to 0.01 Joules per kilogram in any material.

Rem: A special unit of radiation dose equivalent. The dose in rems is numerically equal to the absorbed dose in rads multiplied by the quality factor, the distribution factor, and any other necessary modifying factors. 
Glossary of Terms (Con't)

Roentgen: The special unit of radiation exposure. One roentgen equals $2.58 \times 10^{-4}$ coulomb per kilogram of air.

Spectrometry: Used herein to refer to a process by which gamma or $X$ rays emitted from a radioactive sample can be measured and categorized according to their energy and intensity. The process uses a crystal that emits light, when struck by a gamma or $X$ ray, in proportion to the energy of the ray and an electronic analyzer which receives the light pulses, categorizes them, and stores them for later analysis.

Thermoluminescent: Refers to a material with the ability to sture eniergy and release it in the form of light when heated. Used herein to refer to a type of crystal used as a dosimeter to measure the amount of $X$ or gamma energy absorbed in a specified amount of time.

Turbidity: An expression of an optical property of the fine suspended matter in water. Pure distilled water would equal 0. 
DISTRIBUTION

No. of

Copies

Off-Site

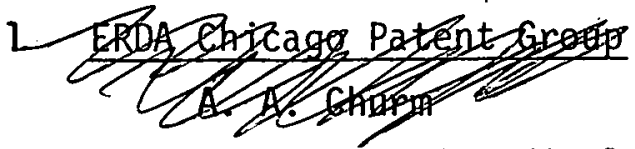

1 . ERDA Office of Biomedical, Environmental Research, and Safety Programs

J. L. Liverman

1 NRC Directorate of Reg. Oper.

$\frac{\text { Region V }}{1990 \text { N. California Blvd., Suite } 202}$ Walnut Creek, Calif. 94596

R. H. Engleken

1 ERDA Division of Reactor Development \& Technology

Asst. Dir. for Nuclear Safety

A. T. Pressesky

222 ERDA Technical Information

\section{Center}

1 ERDA Idaho Operations $\vee$ Operational Safety Division Idaho Falls, Idaho 83401

R. E. Tiller

1. ERDA Headquarters Library ${ }^{2}$ Charles Sherman

5. ERDA Division of Operational Safety

M. R. Biles (4)

A. A. Schoen (1) $r$

1. ERDA Division of Military $r$ Application

Gordon Facer

2 ERDA Division of Production $\checkmark$

G. B. Pleat

E. F. Greenleaf

1 ERDA Nevada Operations Office $r$. Office of Safety

P. 0. Box 14100

Las Vegas, Nevada 89114

W. J. Larkin
No. of

Copies

0ff-Site

5 Environmental Protection Agency Region $X$

Seattle, Washington 98101

E. Cowan

1 Los Alamos Scientific Laboratory.

H. S. Jordan

1 Oregon State Department of $<$ Environmental Quality

1234 SW Morrison

Portland, Oregon 97205

L. B. Day, Director

2 Oregon State Health Division P. 0. Box 231

Portland, Oregon 97207

G. Toombs $r$

M. W. Parratt $r$

1. Washington State Department of Social \& Health Services

1514 Smith Tower

Seattle, Wáshington 98104

R. R. Mooney $r$

1. Washington State-Department of Social \& Health Services P. 0. Bux 1788, MS 56-1 01 ympia, Washington 98504

c. Lewis $\checkmark$

3 Washington State Department of Ecology

O1ympia, Washington 98501

J. A. Briggs $r$

G. Hansen -

J. Raymond $v$

(1) Dakima County Heasth DIStrįt tity late

Yakina, Wasprington

Heakth Officer

$\checkmark$ Benton_Frankhin Heałth Eentery Dasto. washingtop 
Memo

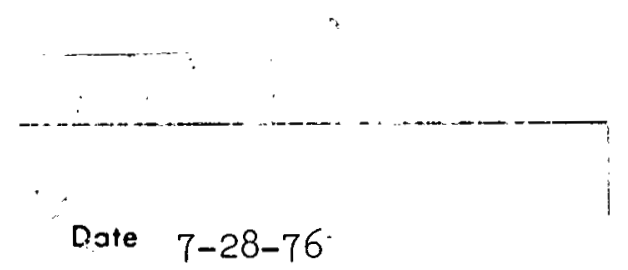

t $\boldsymbol{t}$ o TECHNICAL INFORMATION CENTER.

(BNWL-1979 REV, UC-4I

PLEASE MAKE OFFSITE DISTRIBUTION ACCORDING

TO LABELS INCLUDED.

TIC 222

OTHER OFFSITE COPIES 28

TOTAL COPIES SENT - 250

TECHNICAL INFORMATION DEPARTMENT

BATTELLE-NORTHWEST

RICHLAND, WASHINGTON

From

$84-3000-458(3-68)$ 
No. of

Copies

Off-Site.

1 ERDA Chicago Patent Group

A. A. Churm

1 ERDA Office of Biomedical, Environmental Research, and Safety Programs

J. L. Liverman

1 NRC Directorate of Reg. Oper.

Region V

1990.N. California Blvd., Suite 202 walnut Creek, Calif. 94596

R. H.' Engleken

1 ERDA Division of Reactor Development \& Technology

Asst. Dir. for Nuclear Safety

A. T. Pressesky

222 ERDA Technical Information Center

1 ERDA Idaho Operations Operational Safety Division Idaho Falls, Idaho 83401

R. E. Tiller

i ERDA Headquarters Library Charles Sherman

5 ERDA Division of Operational Safety

M. R. Biles (4)

A. A. Schoen (1)

1 ERDA Division of Military Application

Gordon Facer

2 ERDA Division of Production

G. B. Pleat

E. F; Greenleaf

1 ERDA Nevada Operations Office Office of Safety

P. 0. Box 14100

Las Vegas, Nevada 89114

W. J. Larkin
No. of

Copies

Off-Site

5 Environmental Protection Agency Region $X$

Seattle, Washington 98101

E. Cowan

1 Los Alamos Scientific Laboratory

Los Alamos, New Mexico

H. S. Jordan

1 Oregon State Department of

Environmental Quality

1234 SW Morrison

Portland, Oregon 97205

L. B. Day, Director

2 Oregon State Health Division

P. 0. Box 231

Portland, Oregon 97207
G. Toombs
M. W. Parratt

1 Washington State Department of

Social \& Health Services

1514 Smith Tower

Seattle, Washington 98104

R. R. Mooney

1 Washington State Department of

Social \& Health Services

P. 0. Box 1788, MS 56-1

01 ymp ia, Washington 98504

c. Lewis

3 Washington State Department of Ecology

OTympia, Washington 98501

J. A. Briggs

G. Hansen

J. Raymond

1 Yakima County Health District

City $\mathrm{Ha} 11$

Yakima, Washington 98901

Health Officer

1 Benton-Frankl in Health Center

Pasco, Washington 99301

V. E. Michael 
No. of

Copies

Off-Site (Con't)

1 City of Richland

Water \& Sewer Department.

505 Swift BTvd.

Richland, Washington 99352

K. R. Engstrom

1 Exxon Nuclear

Horn Rapids Rd.

Richiland, Washington 99352

M. L. Smith

On-Site Hanford

14 ERDA Richland Operations Office

0. J. Elgert

P. G. Holsted

L. F. Perkins

P. G. Rhoades

M. W. Tiernan (10)

7 Atlantic Richfield Hanford

Company

G. E. Barkman

G. I... Hanson

R. F. Isaacson

H. L. Maxfield

Keith Price

A. T. White

ARHCO Files

5 United Nuclear, Inc.

T. E. Dabrowski

R. E. Dun

A. E. Engler

N. R. Miller

UNI File

1 Hanford Environmental Health Foundation

R. G. Anderson

1 J.A. Jones Construction Co.

L. L. Crass

3 U. S. Testing Company, Inc.
W. V. Baumgartner
M. M. Lardy
H. E. Oens

No. of

Copies

2 Westinghouse Hanford Company

R. 0. Budd

R. B. Hall

109 Battelle-Northwest

W. J. Bair

P. J. Blumer

L. A. Carter

J. P. Corlcy

C. E. Cushing

G. M. Dalen

J. R. Eliason

J. J. Fix

R. F. Foster

J. J. Fuquay

W. T. Hinds

I. R. Irish

J. J. Jech

L. J. Kirby

H. V. Larson

M. W. Leale

T. J. McLaughl in

D. A. Myers

J. M. Nielsen

D. E. Olesen

H. M. Parker

E. H. Phinney

R. W. Perkins

W. H. Richard

W. D. Richmond

J. M. Selby

C. L. Simpson

J. H. Soehnlein

J. K. Soldat

D. R. Speer (70)

C. M. Unruh

B. E. Vaughan

D. A. Waite

D. G. Watsun

Technical Publications

Technical Information (5) 